ORNL-6833

\title{
U.S. DEPARTMENT OF ENERGY WORKER HEALTH RISK EVALUATION METHODOLOGY FOR ASSESSING RISKS ASSOCIATED WITH ENVIRONMENTAL RESTORATION AND WASTE MANAGEMENT
}

\author{
Prepared for \\ The U.S. Department of Energy \\ in preparation for the \\ Programmatic Environmental Impact Statement \\ RECEIVÉD \\ Prepared by \\ Center for Risk Management, \\ Oak Ridge National Laboratory ${ }^{1 *}$ \\ JUL 109997 \\ OSTI \\ Office of Environmental Compliance and Documentation ${ }^{2}$, \\ University of Tennessee ${ }^{3}$
}

Bonnie P. Blaylock ${ }^{1}$

Janice Legg ${ }^{1}$

Mary Ann Simek ${ }^{3}$

Pat A. Scofield ${ }^{2}$

Jonna Sutherland ${ }^{3}$

Curtis C. Travis ${ }^{1}$

June 1995

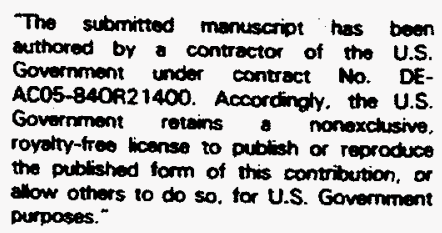

MASTER

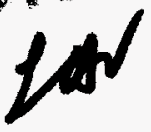

contritution. or

purposes."

Managed by Lockheed Martin Energy Systems, Inc., for the U.S. Department of Energy under contract no. DE-AC05-840R21400. 


\section{DISCLAIMER}

This report was prepared as an account of - work sponsored by an agency of the United States Government. Neither the United States Government nor any agency thereof, nor any of their employees, makes any warranty, express or implied, or assumes any legal liability or responsibility for the accuracy, completeness, or usefulness of any information, apparatus, product, or process disclosed, or represents that its use would not infringe privately owned rights. Reference herein to any specific commercial product, process, or service by trade name, trademark, manufac. turer, or otherwise does not necessarily constitute or imply its endorsement, recommendation, or favoring by the United States Government or any agency thereof. The views and opinions of authors expressed herein do not necessarily state or reflect those of the United States Government or any agency thereof. 


\section{DISCLAIMER}

Portions of this document may be illegible electronic image products. Images are produced from the best available original document. 


\section{CONTENTS}

FIGURES

$\mathrm{v}$

TABLES

vi

ACRONYMS AND ABBREVIATIONS viii

EXECUTIVE SUMMARY

$\mathbf{x i}$

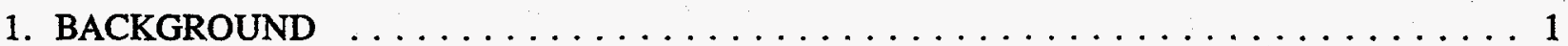

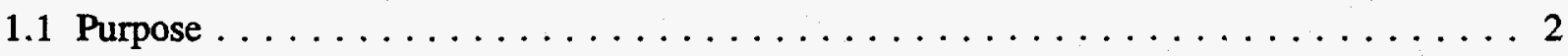

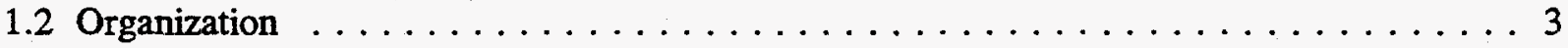

2. DATA COLLECTION AND ANALYSIS $\ldots \ldots \ldots \ldots \ldots \ldots \ldots \ldots \ldots \ldots \ldots \ldots \ldots \ldots$

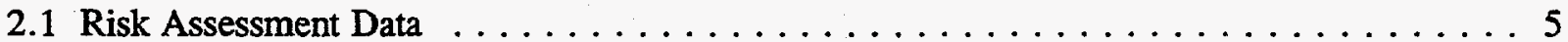

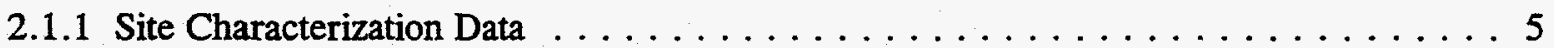

2.1.2 Exposure Scenario Data . . . . . . . . . . . . . . . . 6

2.1 .3 Toxicity Data $\ldots \ldots \ldots \ldots \ldots \ldots \ldots \ldots \ldots \ldots \ldots \ldots \ldots \ldots$

2.1 .4 Dose Estimation Data $\ldots \ldots \ldots \ldots \ldots \ldots \ldots \ldots \ldots \ldots \ldots$

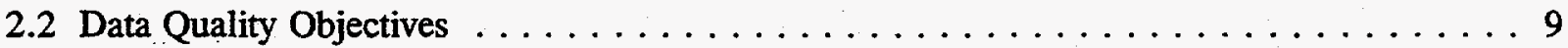

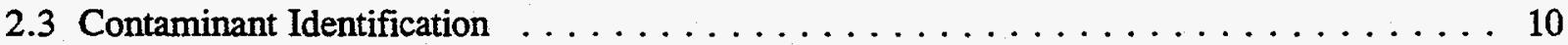

3. IDENTIFICATION OF ACTIVITIES AND WORKERS $\ldots \ldots \ldots \ldots \ldots \ldots \ldots$

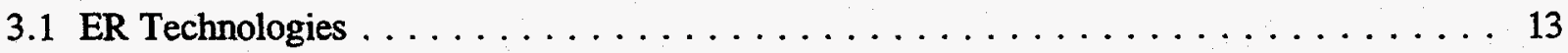

3.2 WM Modules $\ldots \ldots \ldots \ldots \ldots \ldots \ldots \ldots \ldots \ldots \ldots \ldots \ldots \ldots \ldots$

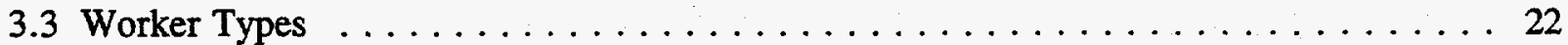

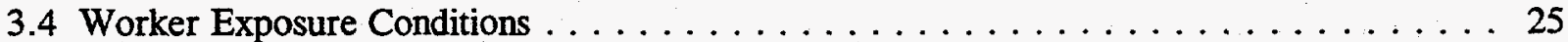

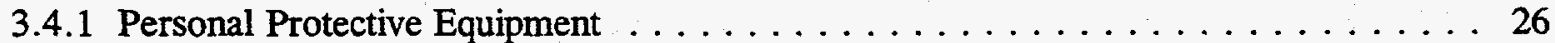

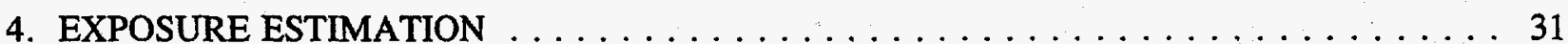

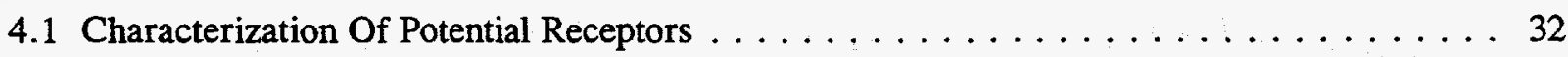

4.2 Identification of Exposure Pathways $\ldots \ldots \ldots \ldots \ldots \ldots \ldots \ldots \ldots \ldots$ 
4.2.2 Identification of Exposure Routes $\ldots \ldots \ldots \ldots \ldots$

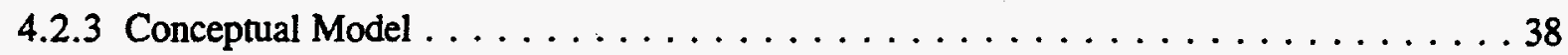

4.3 Identification Of Exposure Scenarios . . . . . . . . . . . . . . . 43

4.3.1 ER Exposure Scenarios (Routine Operations) $\ldots \ldots \ldots \ldots$

4.3.1.1 Remedial Actions . . . . . . . . . . . . . . . . 43

4.3.1.2 Decontamination And Decommissioning (Routine Operations) . . . . . . . . . 44

4.3.2 WM Exposure Scenarios (Routine Operations) $\ldots \ldots \ldots$. . . . . . . . 45

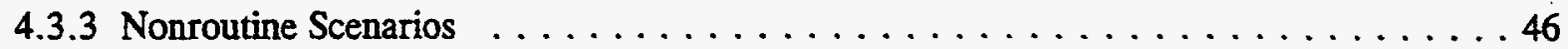

4.4 Quantification of Exposure . . . . . . . . . . . . . . . . 47

5. ESTIMATION OF CHEMICAL INTAKES $\ldots \ldots \ldots \ldots \ldots$

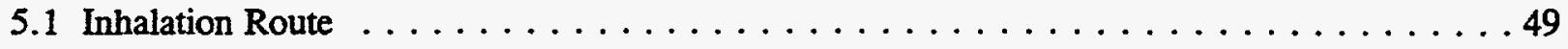

5.1 .1 Emission Rates for Routine Operations $\ldots \ldots \ldots \ldots \ldots \ldots \ldots \ldots \ldots \ldots \ldots \ldots$

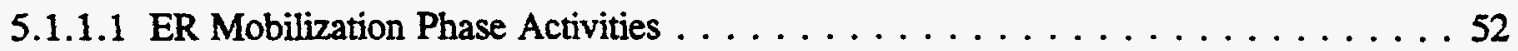

5.1 .1 .2 ER Operation And Maintenance Phase Activities $\ldots \ldots \ldots \ldots$

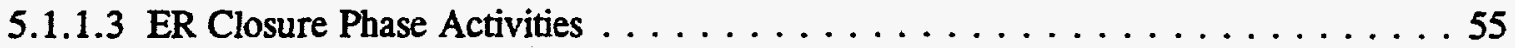

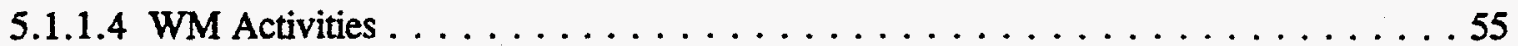

5.1 .1 .5 Estimation Of Source Strengths $\ldots \ldots \ldots \ldots \ldots \ldots \ldots \ldots \ldots \ldots \ldots \ldots \ldots \ldots \ldots$

5.1 .2 Air Concentration Estimation Methods $\ldots \ldots \ldots \ldots \ldots$

5.1 .2 .1 Area Source Models $\ldots \ldots \ldots \ldots \ldots \ldots \ldots$

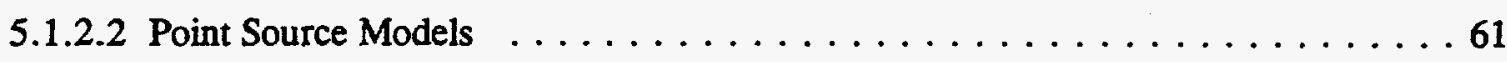

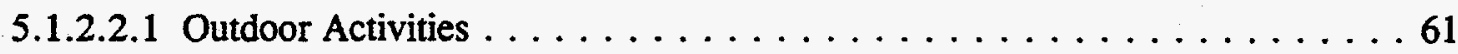

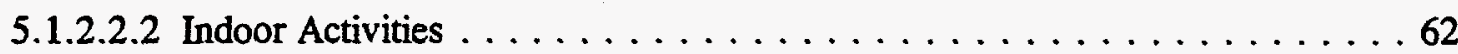

5.1 .2 .3 Exposure Criteria $\ldots \ldots \ldots \ldots \ldots \ldots \ldots \ldots \ldots \ldots \ldots \ldots \ldots \ldots \ldots \ldots$

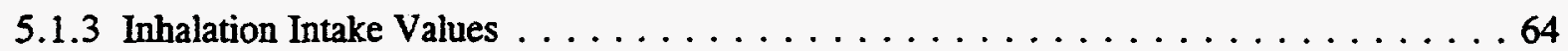

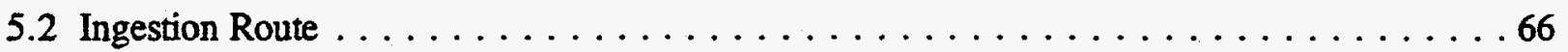

5.3 Example ER Exposure Quantification: Chemical $\ldots \ldots \ldots \ldots$

6. ESTIMATION OF RADIONUCLIDE INTAKES AND DOSES $\ldots \ldots \ldots \ldots \ldots$

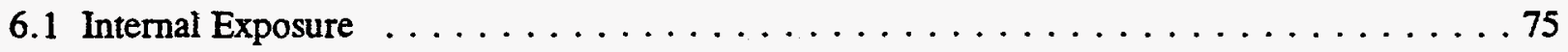

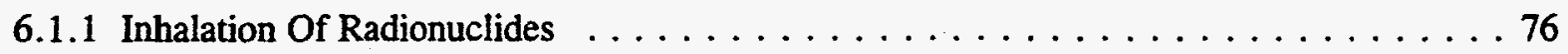

6.1.1.1 Air Concentration Estimation Methods $\ldots \ldots \ldots \ldots \ldots \ldots \ldots \ldots \ldots \ldots \ldots \ldots$

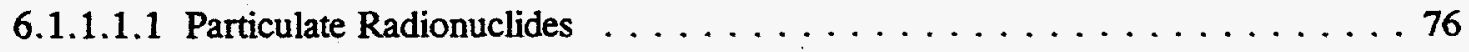

6.1.1.1.2 Vapor And Gas Phase Radionuclides . . . . . . . . . . . . . 77 
6.1.1.2 Inhalation Intakes And EDE Estimation $\ldots \ldots \ldots \ldots \ldots \ldots \ldots \ldots$

6.1 .2 Ingestion Of Radionuclides $\ldots \ldots \ldots \ldots \ldots \ldots \ldots \ldots \ldots \ldots \ldots \ldots \ldots$

6.2 External Exposure $\ldots \ldots \ldots \ldots \ldots \ldots \ldots \ldots \ldots \ldots \ldots \ldots \ldots \ldots \ldots . \ldots \ldots \ldots$

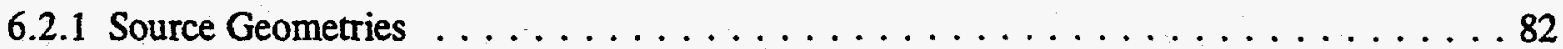

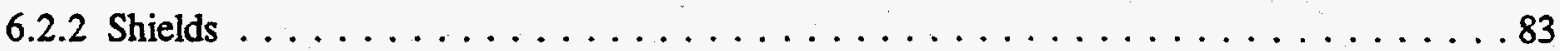

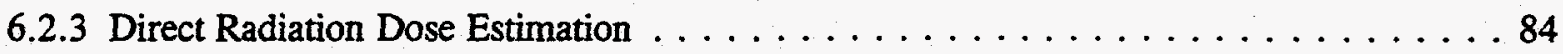

6.3 Example Exposure Quantification: Radionuclide ............... 85

7. ESTIMATING EXPOSURES FROM NONROUTINE EVENTS $\ldots \ldots \ldots \ldots \ldots \ldots$

7.1 Emissions From Nonroutine Events $\ldots \ldots \ldots \ldots \ldots \ldots \ldots \ldots \ldots \ldots \ldots . \ldots \ldots$

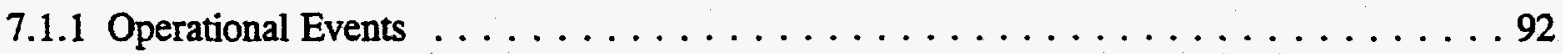

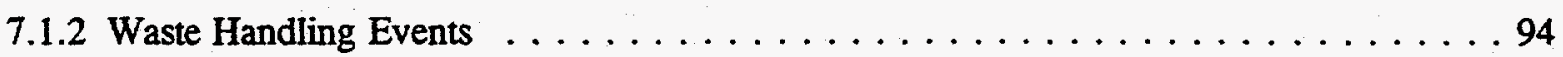

7.1 .3 External Events . . . . . . . . . . . . . . . . . . 96

7.2 Estimating Air Concentrations From Nonroutine Events . . . . . . . . . . 97

7.3 Dose Estimation For Nonroutine Events $\ldots \ldots \ldots \ldots \ldots \ldots \ldots \ldots \ldots \ldots$

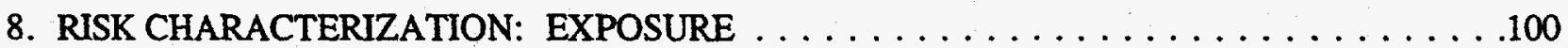

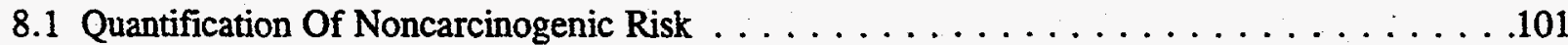

8.2 Quantification Of Carcinogenic Chemical and Radionuclide Risk . . . . . . . . . 103

8.2.1 Example Risk Calculation For Carcinogenic Chemical . . . . . . . . . . . . 107

8.2.2 Example Risk Calculation For Radionuclide . . . . . . . . . . . . . . 107

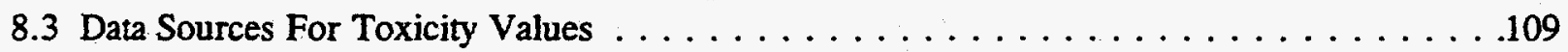

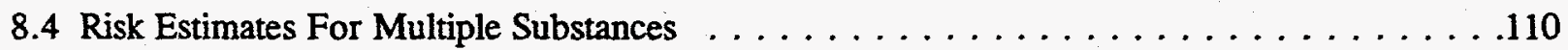

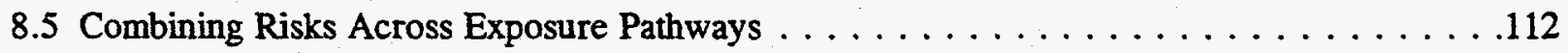

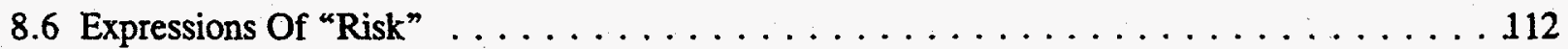

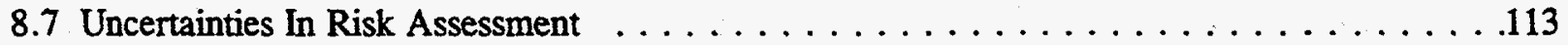

9. RISK CHARACTERIZATION: SAFETY RISKS $\ldots \ldots \ldots \ldots \ldots \ldots \ldots \ldots \ldots \ldots$

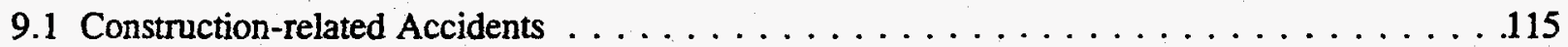

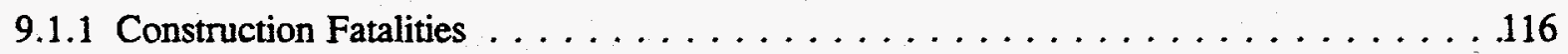

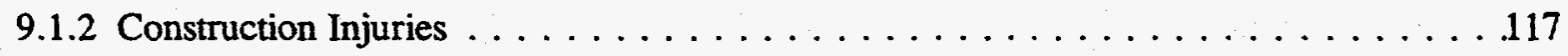

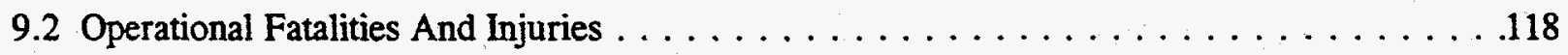

9.3 Heat Stress . . . . . . . . . . . . . . . . . . . . . . . . 119

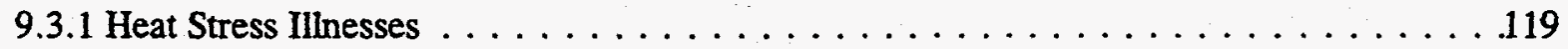




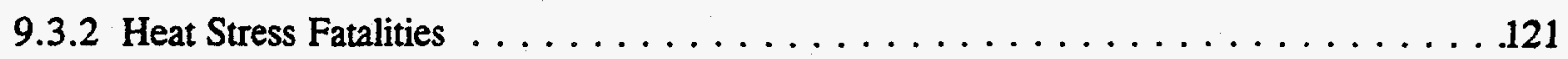

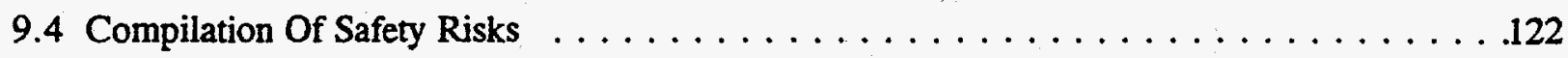

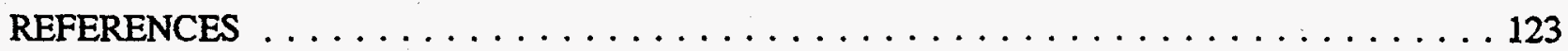




\section{FIGURES}

Figure 3.1-1. ER Remediation Technologies $\ldots \ldots \ldots \ldots \ldots$

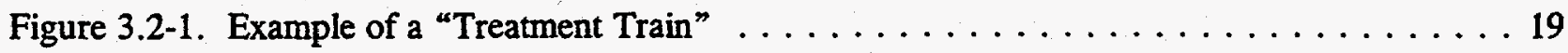

Figure 3.3-1. Example of ER and WM Worker Activities $\ldots \ldots \ldots \ldots \ldots \ldots \ldots \ldots \ldots \ldots$

Figure 4.2-1. Example Representation of an ER Conceptual Model . . . . . . . . . . . . 40 


\section{TABLES}

Table 3.1-1. Activities for Various Technologies . . . . . . . . . . . . . . . 15

Table 3.2-1. Waste Management Activities and Subactivities . . . . . . . . . . . . 19

Table 3.3-1. Examples of ER Activities and Worker Types . . . . . . . . . . . . . 23

Table 3.3-2. Examples of WM Activities and Worker Types . . . . . . . . . . . . . 24

Table $3.4-1$. Personal Protective Equipment $\ldots \ldots \ldots \ldots \ldots \ldots \ldots \ldots \ldots \ldots \ldots$

Table 4.2-1. Examples of Exposure Routes for Remediation Technologies . . . . . . . . . . . . 37

Table 4.2-2. Examples of Exposure Routes for WM Activities . . . . . . . . . . . . 38

Table 4.2-3. Summary Conceptual Model for ER and WM Activities . . . . . . . . . . . . . . 42

Table 5.1-1. Volatile Releases and Associated Technologies . . . . . . . . . . . . . . 50

Table 5.1-2. Particulate $(15 \mu \mathrm{m})$ and VOC Emission Rates from Soils Handling . . . . . . . . 53

Table 5.1-3. VOC Emission Rates for Various Treatment Technologies . . . . . . . . . . . . 54

Table 5.1-4. Particulate Emission Rates for Incineration $\ldots \ldots \ldots \ldots$

Table 5.1-5. Average Fugitive Emission Factors ${ }^{\mathrm{a}, \mathrm{b}} \ldots \ldots \ldots \ldots \ldots$

Table 5.1-6. Release Types and Associated Model Categories . . . . . . . . . . . . . 59

Table 5.1-7. Assigned Protection Factors . . . . . . . . . . . . . . . . . . . . . 64

Table 5.3-1. Person-hours and Exposure Routes for Excavation . . . . . . . . . . . . . 68

Table 5.3-2. PAL Parameters Used in Example Calculation . . . . . . . . . . . . . . 70

Table 5.3-3. Benzene Intake via Inhalation and Ingestion $\ldots \ldots \ldots \ldots \ldots \ldots$

Table 6.2-1. MicroShield Geometries . . . . . . . . . . . . . . . . . . . . . . 82

Table 6.3-1.: Shielding and Personnel Assumptions for Example Site . . . . . . . . . . . 87

Table 6.3-2. EDEs for Each Activity for Direct Radiation . . . . . . . . . . . . . . 88

Table 6.3-3. EDEs for ${ }^{137} \mathrm{Cs}$ and ${ }^{137 \mathrm{~m}} \mathrm{Ba}$ via Inhalation and Ingestion Routes . . . . . . . . . 90

Table 7.1-1. Atmospheric Release Fractions for Nonroutine Events . . . . . . . . . . . 92

Table 8.2-1. Summary of Health Effect Endpoints . . . . . . . . . . . . . . . . . . 106

Table 8.2-2. Risks from Ingestion and Inhalation of Benzene (example) . . . . . . . . . . . 107

Table 8.2-3. Cancer Risks from ${ }^{137} \mathrm{Cs}$ and ${ }^{137 \mathrm{~m}} \mathrm{Ba}$ via Direct Radiation . . . . . . . . . . . . . . 108

Table 8.2-4. Cancer Risks from ${ }^{137} \mathrm{Cs}$ and ${ }^{137 m} \mathrm{Ba}$ via Inhalation and Ingestion Routes . . . . . . . 109

Table 9.1-1. Construction Fatality Rates . . . . . . . . . . . . . . . . . . . 117

Table 9.1-2. Construction Injury Rates $\ldots \ldots \ldots \ldots \ldots \ldots \ldots \ldots \ldots$

Table 9.2-1. Operational Event Risk Factors . . . . . . . . . . . . . . . . . . . 119

Table 9.3-1. Heat-Related Disorders within DOE, 1991 and $1992 \ldots \ldots \ldots$. . . . . . . . . 120

Table 9.3-2. Heat Stress Fatality Rates . . . . . . . . . . . . . . . . . . . 122 


\section{ACRONYMS AND ABBREVIATIONS}

ACGIH American Conference of Governmental Industrial Hygienists

ALARA As Low As Reasonably Achievable

ANSI American National Standards Institute

APF Assigned Protection Factor

ARAR Applicable or Relevant and Appropriate Requirement (cleanup standard)

ATSDR Agency for Toxic Substances and Disease Registry

BLS Bureau of Labor Statistics

CEDE Committed Effective Dose Equivalent

CERCLA Comprehensive Environmental Response, Compensation, and Liability Act

CFR Code of Federal Regulations

Ci Curie

CM Conceptual Model

CPE Chemical Protective Equipment

DCF Dose Conversion Factor

D\&D Decontamination and Decommissioning

DAC Derived Air Concentration

DE Dose Equivalent

DOE U.S. Department of Energy

DOL U. S. Department of Labor

DQO Data Quality Objectives

ECAO Environmental Criteria Assessment Office

EDE Effective Dose Equivalent

EPA U. S. Environmental Protection Agency

ER Environmental Restoration

ET Effective Temperature

FS Feasibility Study

FSOP Field Standard Operating Procedure

FTE Full-time Equivalent

HEAST Health Effects Assessment Summary Tables

HEPA High-efficiency Particulate Air

HI Hazard Index

HLW High-level Waste 
Health Physicist

HQ Hazard Quotient

ICRP International Commission on Radiological Protection

IDLH Immediately Dangerous to Life or Health

IH Industrial Hygienist

IRIS Integrated Risk Information System

MRL Minimum Risk Level

NCRP National Council on Radiation Protection and Measurements

NEPA National Environmental Policy Act

NIOSH National Institute for Occupational Safety and Health

NOAEL No Observed Adverse Effect Level

NRC National Research Council

NSC National Safety Council

O\&M Operation and Maintenance

ORNL Oak Ridge National Laboratory

OSHA Occupational Safety and Health Administration

PA Preliminary Assessment

PAL Point, Area, and Line model

pCi picoCurie

PEF Particulate Emission Factor

PEIS Programmatic Environmental Impact Statement

PEL Permissible Exposure Limit

$\mathrm{PM}_{10} \quad$ Particulate Matter (with a diameter of $<10 \mu \mathrm{m}$ )

PPE Personal Protective Equipment

RAGS Risk Assessment Guidance for Superfund

RCRA Resource Conservation and Recovery Act

REL Recommended Exposure Limit

RfC Reference Concentration

RfD Reference Dose

RI Remedial Investigation

SAR Safety Analysis Report

SCBA Self-contained Breathing Apparatus

SI International System

SIC Standard Industrial Classifications 
SPMS Safety Performance Measurement System

STEL Short Term Exposure Level

SVE Soil Vapor Extraction

$\mathrm{T}_{\text {adj }} \quad$ Adjusted temperature

TLV Threshold Limit Values

TRC Total Recordable Cases

TSD Treatment, Storage, and Disposal

TWA Time-weighted Average

VF : Volatilization Factor

VOC Volatile Organic Compound

WBGT Wet Bulb Globe Temperature

WGT Wet Globe Temperature

WM Waste Management 


\section{EXECUTIVE SUMMARY}

This document describes a worker health risk evaluation methodology for assessing risks associated with Environmental Restoration (ER) and Waste Management (WM). The methodology is appropriate for estimating worker risks across the Department of Energy (DOE) Complex at both programmatic and sitespecific levels. This document supports the worker health risk methodology used to perform the human health risk assessment portion of the DOE Programmatic Environmental Impact Statement (PEIS) although it has applications beyond the PEIS, such as installation-wide worker risk assessments, screening-level assessments, and site-specific assessments.

The worker health risk evaluation presented here, in accordance with Environmental Protection Agency (EPA) guidance, involves four steps:

- Identification of workers and activities,

- Exposure assessment,

- Toxicity assessment,

- Risk characterization.

Workers, activities, and subactivities are identified to determine the numbers and types of workers involved in a given activity. Once worker types, activities, and worker configurations (i.e., distances from the source and available shielding) are determined, dose assessment models and facility- and technologyspecific emission estimates are used to predict occupational exposures at the site where technologies are being used for site remediation or for treatment, storage, and disposal (TSD) activities. The primary models used for assessing risks are MicroShield for direct radiation, the Point, Area, and Line (PAL) model for predicting air concentrations from area sources, TSCREEN for predicting air concentrations from point sources, and a room model for predicting indoor air concentrations.

With the aid of computer modeling, the inhalation and direct radiation portions of the worker exposure assessment are conducted to identify possible transport media and exposure routes through which contaminants might reach the workers at a site or facility. The ingestion exposure route is also evaluated 
in the exposure assessment; however, it can be evaluated without using elaborate computer codes. Intake values or doses are calculated as part of the exposure assessment based on contaminant concentrations, exposure durations, available shielding, and other necessary parameters. The exposure scenario being evaluated determines the exposure pathways that are assessed. This document provides detailed mathematical formulas used to estimate intakes and doses from given exposure routes.

The toxicity assessment evaluates the potential for contaminants of concern to cause adverse health effects in exposed individuals. Appropriate cancer potency factors (for chemical carcinogens), risk factors (for radionuclides), and reference doses (RfDs) (for chemical noncarcinogens) are used to assess the toxicity of the contaminants to which workers might be exposed. For noncarcinogens, depending on the exposure duration, toxicity values can be chronic, subchronic, or acute. For the ER worker risk assessment, where work shift durations are limited, subchronic and acute values are more often used. For the WM worker risk assessment, chronic toxicity values are used for workers laboring at least 10 years, and acute toxicity values for chemicals are used for nonroutine conditions.

Finally, the toxicity and exposure assessments are integrated and summarized into qualitative and quantitative expressions of risk in the risk characterization step. Intake or dose estimates are multiplied by toxicity values to estimate chemical or radionuclide cancer risks or to calculate a noncarcinogenic hazard quotient for individuals potentially exposed via a given exposure pathway and route. Once all potential exposure pathways, routes, and time periods have been evaluated, risk estimates and hazard quotients are summed when appropriate to yield an estimate of total carcinogenic risk or noncarcinogenic hazard index. Risk to individuals can be expressed as average or maximum. Risk to populations are expressed as the probability of cancer incidence, cancer fatalities, and genetic effects in the population.

Once the risk estimations are complete an uncertainty evaluation is performed to determine the uncertainties inherent in the risk assessment process, uncertainties associated with the chosen models, and uncertainties associated with scenarios and parameters used. For the PEIS analysis, a qualitative uncertainty analysis is conducted. While it is preferable to perform a detailed, quantitative uncertainty analysis, in some cases (such as screening-level or programmatic analyses), detailed, quantitative uncertainty analyses are neither feasible nor warranted. 
The worker health risk evaluation methodology described in this document is applicable to remediation workers and TSD workers directly involved with waste handling and treatment. The methodology does not apply to onsite general employees or office workers.

This methodology can be applied to evaluate routine ER activities, routine operations of WM facilities, and nonroutine scenarios. This document is intended to present the conceptual methodology for calculating worker risks on various levels ranging from a screening level to the site-specific level. Specific assumptions and approaches used in the PEIS health risk evaluations are described in two documents (ORNL, 1995a, 1995b). 


\section{BACKGROUND}

Remediation of DOE's 13,000 facilities and management of the current and future waste streams will require the effort of thousands of workers. Workers, as defined here, are persons who directly participate in the cleanup of DOE waste sites or facilities or in the handling, treatment, and storage of waste. Workers are in this way different from general onsite employees, who are not directly involved with remediation or waste handling and who are generally located in buildings away from such activities. Remediation activities include the use of remediation technologies such as bioremediation, surface water control, and excavation of contaminated soils. Waste management activities include such tasks as over packing drums for storage of waste, operating treatment facilities such as incinerators, and preparing containers of waste for shipment to disposal areas. The objective of the worker health risk evaluation is to provide guidance in assessing the worker risks posed by activities at DOE facilities. This report documents a methodology that can be used to evaluate potential risks to both remediation and TSD workers. This conceptual methodology is the basis for the worker risk evaluation conducted for the PEIS; however, it has applications beyond the PEIS.

Every remediation alternative or TSD option has various benefits and risks assaciated with it. Actions to remediate sites and manage waste throughout the DOE complex will entail risks to workers. In many circumstances, such activities will create the potential for exposure that is not present without cleanup or waste management activities. In addition, cleanup actions will redistribute existing health risks over time and will likely shift health risks to remediation and waste management workers in the short term. Risks posed to workers during cleanup and WM facility operations should be a primary factor in determining the tradeoffs in planning such activities. The objective of the worker risk assessment is to evaluate and document the assessment of types and magnitudes of potential adverse impacts on workers from each remediation alternative or TSD option. The worker risk assessment evaluates the short-term effectiveness of the alternative or option in protecting the workers during site remediation or waste management activities.

ER and WM operations pose potential risks to workers through exposure to carcinogenic and noncarcinogenic contaminants in various environmental or structural media (e.g., air, soil, and contaminated surfaces). Workers also face physical construction hazards (e.g., use of heavy equipment, 
trenching, electrical hazards), operational hazards (injuries and fatalities due to routine operations), and heat stress associated with the work activity and/or the use of personal protective equipment (PPE). The scope of this methodology encompasses methods for estimating these risks.

The worker risk assessment is conducted by the following steps:

- Contaminant identification and characterization,

- Identification of remediation (ER) and WM activities and subactivities,

- Identification of worker types and person-hours for each activity,

- Estimation of doses and intakes for each activity,

- Risk characterization of exposure-related risks and physical hazards.

\subsection{Purpose}

The purpose of this report is to provide a generic screening-level methodology for assessing worker risks posed by implementation of remediation and waste management activities across the DOE complex. The methodology, along with other EPA and DOE guidance documents, is intended to serve as prospective guidance for evaluating worker health risks for a number of potential applications, including the DOE PEIS. The methodology is useful for both screening-level and more site-specific applications. For example, screening-level analyses might include programmatic assessments based on generic assumptions, remediation planning phase assessments, and planning phase assessments for developing Health and Safety Plans and medical surveillance programs for identifying potential concerns before beginning operations. In these types of screening-level analyses, worker exposure data may be limited or unavailable due to the hypothetical nature or "planning phase" nature of the assessments. This methodology provides guidance on performing an assessment of this type by estimating exposures using EPA default emission rates and various computer models to estimate air concentrations.

For more site-specific analyses, the basic methodology for assessing worker risks is also applicable. However, exposure calculations and modeling can be replaced with actual monitoring data, known emission rates and air concentrations, known exposure durations, and specific, planned worker tasks, when available. 
Two separate documents have been produced (ORNL, 1995a, 1995b) to describe the specific applications of this conceptual methodology for the PEIS; in particular, those documents describe a unit dose approach and a unit risk approach to assessing human health risks. Potential users of theses methodologies include experienced or novice risk assessors who are performing installation-wide worker risk assessments. This methodology does not provide information on policy useful to risk managers or decision-makers.

Risk estimates resulting from the use of this methodology are useful for comparative analyses, but in most cases they should not be construed to represent actual, site-specific worker risks unless known, site-specific data are used. The methodology described here is often based on conservative assumptions and hypothetical scenarios that may not represent actual site-specific conditions. When actual air concentrations and dosimetry data are unavailable, this type of approach is feasible. Moreover, this approach can be useful for providing insight into the relative contribution of certain activities to worker exposures and risks. The use of site-specific parameter values, when such values are available, is preferred and is useful in providing less conservative estimates.

\subsection{Organization}

This document uses general guidelines of a Comprehensive Environmental Response, Compensation, and Liability Act (CERCLA) assessment suggested in the Risk Assessment Guidance for Superfund (RAGS) (EPA 1989a) but does not follow CERCLA guidance in detail. In addition, key principles outlined in other important EPA and DOE guidance documents are addressed. These guidance documents, referenced throughout the methodology should be used in conjunction with this methodology. Major topics are presented in the following order:

Chapter 1. Background. Includes objectives, purpose and background of the worker health risk evaluation.

Chapter 2. Data Collection and Analysis. Describes the process for collecting site or facility characterization data, exposure scenario data, toxicity data, and dose estimation data. 
Chapter 3. Identification of Activities and Workers. Provides a discussion of ER and WM activities, subactivities, and worker types used to assess exposures and risks to workers performing these activities.

Chapter 4. Exposure Estimation. Provides a discussion of the three elements needed to estimate exposure: (1) exposure setting, (2) exposure pathways, and (3) exposure quantification. Chapter 4 also includes a description of the conceptual models used, assumptions about exposure pathways and exposure routes evaluated, exposure scenarios, and receptors, and samples of activities evaluated.

Chapter 5. Estimation of Chemical Intakes. Describes inhalation and ingestion, two of the exposure routes for exposure to chemicals, and justification for omitting other exposure routes. Chapter 5 also includes equations used to estimate exposure via inhalation and ingestion, and describes the process of estimating air concentrations using estimated emission rates.

Chapter 6. Estimation of Radionuclide Intakes and Doses. Describes internal and external radiation exposure routes, including equations used to estimate exposure.

Chapter 7. Estimating Exposure from Nonroutine Events. Describes various nonroutine exposure scenarios and methods to estimate air concentrations and doses from nonroutine conditions.

Chapter 8. Risk Characterization: Exposure-Related Risks. Combines exposure and toxicity information to quantify worker risk; describes presentation of risk estimates in terms of individual and population risk.

Chapter 9. Risk Characterization: Safety-Related Risks. Describes injury and fatality rates for construction and operational hazards and heat stress; provides information on estimating safety-related risks and their combination with health risks. 


\section{DATA COLLECTION AND ANALYSIS}

Data collection and analysis involves gathering and evaluating data relevant to the worker health risk evaluation. Data should be continually updated as significant improvements and new data become available. These data must also adhere to data quality objectives (DQOs), statements that specify the quality of data required to support decisions about ER and WM activities. This chapter describes the data requirements and DQOs for conducting a health risk assessment.

\subsection{Risk Assessment Data}

The categories of data required for performing a worker health risk assessment include the following:

- Site or facility characterization data

- Exposure scenario data

- Toxicity data

- Dose estimation data.

These data categories and their uses are described in the following subsections. As these descriptions indicate, the data requirements for each category may overlap.

\subsubsection{Site Characterization Data}

Site-specific data are always preferable over generic values when doing a risk assessment. In the absence of site-specific data, however, default exposure values (EPA 1988a, 1989b) and modeling parameters can be used. When neither site-specific nor standard values are available, reasonable assumptions about these values can be made based on guidance given by EPA (1988a; 1989b) or professional judgement. 
Before estimating exposures and risks, the site or facility in question must first be identified and described to define the scope of the problem. This initial description comprises site characterization, and it gives the assessor information about contaminants present at the site or facility and the condition of the environmental media or layout of the WM TSD facility. Site or facility characterization data, depending on their quality, may indicate the extent of contamination in the environment and/or the types of contaminants present in a source. As described in EPA (1989a), the extent of contamination is determined by examining concentrations of contaminants that can be attributed to releases from the site or facility. Site or facility characterization data include the following:

- History of the previous uses of the facility or site,

- Dimensions of the site or facility,

- Dimensions of the source within a site (e.g., drums on a palette or an area of contaminated soil),

- Type of contaminants present and the inventory of these contaminants,

- Treatment processes that occur within a waste management facility (e.g., what are activities that occur and how are they accomplished, by contact or remote handling).

Sources of this information include site descriptions and data from preliminary assessments (PA), safety analysis reports (SAR), and remedial investigation (RI) reports. In addition, site characterization data, such as are required for site health and safety plans, may be useful. Criteria for these data may be found in 29CFR1910.120(c).

\subsubsection{Exposure Scenario Data}

Exposure scenarios illustrate the circumstances under which exposure may occur. Exposure, as defined by this methodology and by the Occupational Safety and Health Administration (OSHA), occurs if a hazardous substance is present and potential for release of that substance exists such that the worker may come into contact with it. Exposure scenario data include information about worker locations and behavior patterns as well as certain types of environmental setting information. The types of exposure scenario data needed include the following:

- Source configuration

- Contaminant inventory 
- Contaminant concentrations in environmental or structural media (soil, air, contaminated surfaces)

- Physical and chemical properties of contaminants

- Emission rates of contaminants from contaminated areas during remediation or WM processes

- Source-to-receptor distances

- Source shielding radionuclides

- Technologies

- Characterization of media disturbance (i.e., how much contaminated soil is excavated)

- Atmospheric data and/or facility ventilation rates.

Site reports and documents provide data on contaminant sources. Emission rate data can be derived from engineering studies and EPA technology-specific reports.

\subsubsection{TOXICITY DATA}

Toxicity data are used to estimate the hazard potential of contaminants present at a site. Toxicity data used in the worker risk evaluation process can be obtained from EPA sources such as the Integrated Risk Information System (IRIS), EPA's on-line toxicity value database. IRIS is the preferred source for numerical toxicity values and information. This system provides chemical-specific cancer potency factors, RfDs, reference concentrations (RfCs), supporting discussion, and references. Health Effects Assessment Summary Tables (HEAST) is a tabular presentation of toxicity information and values, which is used as a secondary source to IRIS. Toxicity data include the following:

- Cancer potency factors for carcinogens,

- Reference doses and reference concentrations for noncarcinogens,

- Dose conversion factors for radionuclides,

- Toxicological properties of contaminants,

- Known significant health effects resulting from exposure to a contaminant.

Toxicologists should review the RfD values and modify them when appropriate to account for differences in exposure durations between the worker and the general public, for which RfDs were originally derived. Subchronic RfD values are used for ER worker exposure calculations. 


\subsubsection{DOSE Estmation Data}

Dose estimation data are used to estimate intakes or doses of chemicals and radionuclides. Data used to estimate exposures include values for parameters that quantitatively describe exposure scenarios. These parameters include the following:

- Exposure duration

- Body mass

- Inhalation rates

- Ingestion rates

- Worker type

- Intakes or doses (obtained from computer modeling or dosimetry data)

- Averaging time

- Type and effectiveness of PPE worn during the activity.

Exposure duration is the time period over which an exposure event occurs. The exposure duration will vary depending on the amount of time spent implementing a technology. Body mass is generally assumed to be $70 \mathrm{~kg}(154 \mathrm{lb})$ for an adult worker. Inhalation and ingestion rates are generally EPA default values, but these vary based on the level of activity being performed (i.e., light, moderate, or heavy). The averaging time depends on the type of toxic effect being assessed (e.g., noncarcinogenic or carcinogenic).

Historical occupational exposure data for specific activities are the best data to use if the specific exposure scenarios are known. However, applying historical exposure records to new situations or scenarios can pose problems, such as those listed below:

- The specific contaminants that contributed to the historical dose are not always known.

- Specific activities of workers whose doses were recorded are not always known.

- Future contaminant concentrations and characteristics and exposure scenarios may differ substantially from those for which historical data are available.

- Comparable data for all activities at all facilities and DOE installations are not available.

For ER and WM comparative analyses, comparable exposure data are needed for each relevant DOE installation, each type of facility and worker activity, and for installation- or site-specific contaminant inventories and concentrations. To meet these requirements, dose assessment models can be used to 
estimate worker exposure data of consistent quality that would allow meaningful comparison of WM and ER altematives. These exposure estimates can be based on consistent assumptions about worker activities, worker protection, and exposure scenarios throughout the analysis. Historical exposure data, if available, and regulatory and administrative exposure limits are compared with modeled dose estimates as a means of verification. This methodology uses a reasonably conservative (rather than worst case) approach to estimating doses and exposure.

\subsection{Data Quality Objectives}

DQOs are qualitative and quantitative statements that specify the quality of data required to support decisions about remedial and WM activities. Data of known or acceptable precision, accuracy, completeness, representativeness, and comparability are required for risk assessment. Indeed, the development of DQOs is an important step in assuring quality data for site or facility characterization, fate and transport modeling, and exposure estimation. These objectives are established before data collection during the project scoping and sampling and analysis planning phases.

To define DQOs, the problem to be resolved at the site or facility must be defined. Each site and facility has a unique history; therefore, a unique set of DQOs is developed for each site and facility. DQOs also vary according to the intended uses of the collected data. For instance, data may be collected to support risk assessment decisions. Hence, the DQOs serve as the full set of constraints necessary to specify a level of acceptable uncertainty during risk assessment decisions.

EPA guidance provides a three-stage process for developing DQOs (EPA 1989b). These interactive stages include the following:

(1) Identification of decision types. The first stage of the DQO process defines the types of decisions that will be made by identifying data users, evaluating available data, developing a conceptual model, and specifying objectives for the project. During this stage of DQO development, all available site or facility information is compiled and analyzed to develop a conceptual model that describes suspected sources, contaminant pathways, and potential receptors. This stage defines objectives and identifies data gaps. 
(2) Identification of data uses/needs. This stage stipulates criteria for determining data adequacy. Risk assessments, for example, may use data to evaluate the threat posed by a site or facility to workers. Thus, risk assessment data needs include site- or facility-specific contaminants and exposure data. These data are generated through the sampling and analysis of environmental and biological media, particularly where human exposure is likely. Risk assessment data must represent as closely as possible the conditions at a site or facility, allow accurate estimation of risk, and meet regulatory requirements for risk assessment data.

(3) Design of data collection program. In determining DQOs, the methods by which data of acceptable quality and quantity are obtained to make decisions must be defined. This information is summarized in documents such as work plans or sampling and analysis plans.

The use of DQOs ensures that data collected to conduct a risk assessment are of known and documented quality. For risk assessments conducted on a programmatic basis rather than a site-specific basis, the DQO is to use the best available data rather than sampling data. First, data extracted from Resource Conservation and Recovery Act (RCRA)/CERCLA action-confirmed analytical documents that have met rigorous DQOs should be used when available. In cases where no such data exist, unconfirmed or projected data are used and identified as such in accordance with National Environmental Protection Act (NEPA) implementing regulations. The quality of unconfirmed data will vary between DOE installations depending on the maturity of that installation's ER and WM programs. However, all data used in DOE ER and WM evaluations should be reviewed for concurrence by appropriate staff.

\subsection{Contaminant Identification}

An important element of the worker risk evaluation is identification of contaminants of concern. Identification of contaminants of concern requires a close examination of the contaminant concentrations present at a site or WM facility, the physical and chemical properties of the contaminants, the toxicity of the contaminants, characterization of the waste stream, the quality of environmental sampling and worker monitoring data, and the potential for worker exposure to site-related contaminants.

Site reports and documents should identify contaminants found in environmental media. Such reports also provide information about sampled media, sampling techniques, detection limits, and detected 
concentrations. Before using these environmental data to reach conclusions in the risk assessment, however, the data should be checked for completeness. In addition, sampling and analytical techniques used to obtain the data should be examined for accuracy to ensure data quality.

At most DOE facilities, contaminants include radionuclides, carcinogenic chemicals and noncarcinogenic chemicals. These contaminants fall into groups of contaminants such as inorganic chemicals, volatile organic compounds (VOCs), semi-volatiles, and radionuclides. These types of contaminants react differently in environmental or structural media depending on temperature, climate, soil types, wind speed, and precipitation. Chemicals have different affinities for binding to water or soil, different solubilities, and different diffusivities that determine the general behavior of contaminants in environmental media.

All contaminants detected at a site should be considered to be of potential concern. For certain sites, the list of contaminants may be lengthy. Including a large number of contaminants in a risk assessment may be complex as well as time- and resource-consuming. In such situations, a reduction in the number of contaminants of concern is desirable if possible. The empirical evidence at hazardous waste sites is that relatively few contaminants will drive the overall risk posed by a release site. The ultimate number of contaminants evaluated in a risk assessment depends on the cost and schedule of the evaluation and is determined by the risk manager and the person conducting the assessment. Contaminants can be excluded from the risk assessment based on several criteria explained below.

Contaminants of concern are likely to have been identified during a baseline risk evaluation, before the decision to involve workers in the remediation of a site or waste handling at a TSD facility. If this is the case, the contaminants of concern are already known. If, however, contaminants at a site or facility are unknown and remediation or waste handling is to occur, contaminants can be excluded from the risk evaluation based on the following criteria:

- Historical information. Contaminants that have been reliably associated with site activities based on historical records generally should not be eliminated from the risk assessment, even if the other criteria included in this section suggest that such an elimination is feasible. Historical information from other, similar sites may also be used.

- Concentration and toxicity. Contaminants exceeding maximum reported background concentrations should be included in the risk evaluation as contaminants of potential concern. For remedial alternatives, a significant risk could be posed by non-elevated background contaminant 
concentration levels for certain alternatives or activities (e.g., naturally elevated soil leveis of arsenic for an excavation activity) but not for others (same area with a non-intrusive activity). When evaluating remedial alternatives, therefore, selection of contaminants cannot always be based solely on elevated background levels of contaminants.

Site reports and other documents may contain concentration data that provide a preliminary indication of the contaminants detected at the highest concentrations and the greatest frequencies. Before eliminating potentially carcinogenic contaminants, however, the EPA weight-of-evidence classification (an indication of the quality and quantity of data underlying a chemical's designation as a potential human carcinogen) should be considered along with the contaminant concentrations detected at the site. For example, it may be practical and conservative to retain a chemical that is present in low concentrations if that chemical is a Group A carcinogen (see section 8.2).

- Special exposure routes. Certain exposure routes must be considered carefully. For example, highly volatile contaminants may pose a significant inhalation risk due to the likelihood, under certain conditions, that the chemical would be made available for inhalation, (e.g., vaporization of chemicals into the air through soils). Conversely, contaminants with low vaporization potentials (e.g., metals) that are present in high concentrations could pose a risk due to the volume of contaminant available if a transport mechanism exists, such as mechanical disturbance or leaching into water. Such contaminants should be listed as contaminants of concern.

- Applicable or Relevant and Appropriate Requirements (ARARs). The term ARAR covers two sets of cleanup requirements: (1) applicable requirements (applicable by law) and (2) relevant and appropriate requirements (not legally applicable). ARARs can be chemical-specific, locationspecific, or action-specific. Contaminants with ARARs usually should not be excluded from the risk evaluation. This may, however, depend in part on how the contaminant's concentrations in specific media compare with its ARAR concentrations for those media (EPA 1989a).

Given the contaminant profile, personnel should be monitored for exposure to contaminants with high concentration or toxicity during remediation or waste treatment and handling activities to ensure worker safety. 


\section{IDENTIFICATION OF ACTIVITIES AND WORKERS}

Once the contaminants of concern at a site or facility have been identified and characterized, risk managers can better outline safe worker activity options since waste treatment or remediation technologies and the types of worker protection offered depend on the types of contaminants present. The following sections describe some of the most commonly used remediation technologies, the activities involved in the implementation of these technologies, and the types of workers necessary to perform these activities.

\subsection{ER Technologies}

New site remediation technologies are continually emerging through technology development efforts. Although many technologies are currently available, in general, some of the most commonly used are listed in figure 3.1-1.

Most of these technologies have three stages or phases from the start of the process to its completion. These phases, developed solely for the purpose of grouping activities for this methodology, are mobilization, operation and maintenance (O\&M), and closure/post closure. The mobilization phase consists of site preparation activities such as materials gathering, site scoping, and initial steps of technology implementation. The O\&M phase consists of technology implementation such as feeding materials into incineration systems, use of heavy equipment for excavation, or construction of slurry walls. The closure/post closure phase consists of remediation closure tasks such as decontamination procedures, transportation of equipment offsite, and removal of debris produced during the O\&M phase.

For a specific remediation or waste handling task, types and numbers of workers are identified and risks are estimated. Risk estimates for activities are then added to yield the risk for the total technology. Examples of activities that might comprise these ER technology phases are identified in the following table. The authors recognize that the activities presented in the following table are not comprehensive; detail is dependent on the needs of the user of this methodology. At a programmatic or planning level, these 
activities may suffice for performing a worker risk assessment. For a more detailed job/task analysis, more specific breakdowns of tasks are needed. The activities listed below are only examples of major activities.

\begin{tabular}{|l|}
\hline air stripping \\
backfilling \\
carbon sorption (liquid) \\
chemical treatment (ion exchange, \\
oxidation/reduction \\
constructed barriers (dikes and berms) \\
demolition (of buildings and equipment) \\
dredging \\
drum removal \\
ex-situ soil washing \\
ex-situ biotreatment \\
ex-situ vitrification \\
ex-situ chemical treatment of soil \\
excavation \\
extraction (pumping wells)
\end{tabular}

\begin{tabular}{|l|}
\hline gravity separation \\
in-situ vitrification \\
in-situ solidification/stabilization \\
in-situ bioremediation \\
incineration \\
packaging of solid waste \\
power washing \\
precipitation/filtration \\
slurry wall \\
soil vapor extraction (in-situ air \\
stripping/sparging \\
solvent extraction \\
surface water control \\
torch/mechanical cutting
\end{tabular}

Figure 3.1-1. ER Remediation Technologies.

The technologies and activities in this methodology are general ER technologies and activities. For sitespecific applications, more subactivities can be chosen and developed for evaluation to accurately reflect individual site concerns. For the PEIS, the technologies and activity phases listed differ somewhat from those listed here; however, the application and methodology for using technology and activity information remains the same. 
Table 3.1-1. Activities for Various Technologies

\begin{tabular}{|c|c|c|}
\hline Technology & Phase & Activities \\
\hline \multirow[t]{2}{*}{ Excavation of Contaminated Soil } & Mobilization & - Site preparation \\
\hline & O\&M & $\begin{array}{l}\text { - Excavate contaminated soil } \\
\text { - Monitor and sample during excavation } \\
\text { - Decontamination and Decommissioning (D\&D) } \\
\text { equipment } \\
\text { - Package contaminated material } \\
\text { - Transport contaminated soil }\end{array}$ \\
\hline \multirow[t]{3}{*}{ Extraction Wells } & Mobilization & $\begin{array}{l}\text { - Site preparation } \\
\text { - Install wells } \\
\end{array}$ \\
\hline & O\&M & $\begin{array}{l}\text { - Operate well system } \\
\text { - Maintenance } \\
\end{array}$ \\
\hline & Closure/Post Closure & $\begin{array}{l}\text { - D\&D equipment } \\
\text { - Monitor and sample wells }\end{array}$ \\
\hline \multirow[t]{3}{*}{ Surface Water Control } & Mobilization & $\begin{array}{l}\text { - Site preparation } \\
\text { - Construct System } \\
\end{array}$ \\
\hline & O\&M & $\begin{array}{l}\text { - Excavate and construct control device } \\
\text { - D\&D equipment }\end{array}$ \\
\hline & Closure/Post-Closure & $\begin{array}{l}\text { - D\&D equipment } \\
\text { - Monitor and sample wells }\end{array}$ \\
\hline \multirow[t]{2}{*}{ Capping } & Mobilization & $\begin{array}{l}\text { - Site preparation } \\
\text { - Level/Lay sub-base } \\
\end{array}$ \\
\hline & O\&M & $\begin{array}{l}\text { - Install cap layers } \\
\text { - Monitor } \\
\end{array}$ \\
\hline \multirow[t]{3}{*}{ Drum Removal } & Mobilization & $\begin{array}{l}\text { - Site preparation } \\
\text { - Excavate overburden }\end{array}$ \\
\hline & O\&M & $\begin{array}{l}\text { - Excavate contaminated material } \\
\text { - Remove and inspect drum } \\
\text { - Transport to temporary storage }\end{array}$ \\
\hline & Closure/Post-Closure & - D\&D equipment \\
\hline \multirow[t]{3}{*}{ Package Solid Waste } & Mobilization & - Site preparation \\
\hline & O\&M & $\begin{array}{l}\text { - Overpack } \\
\text { - Transport to temporary storage } \\
\end{array}$ \\
\hline & Closure/Post-Closure & - D\&D equipment \\
\hline
\end{tabular}


Table 3.1-1 Activities for Various Technologies, continued.

\begin{tabular}{|c|c|c|}
\hline Technology & Phase & Activities \\
\hline \multirow[t]{3}{*}{ Slurry Wall } & Mobilization & - Site preparation \\
\hline & O\&M & $\begin{array}{l}\text { - Excavate slurry trench } \\
\text { - Fill trench } \\
\text { - Install monitoring wells }\end{array}$ \\
\hline & Closure/Post-Closure & $\begin{array}{l}\text { - D\&D equipment } \\
\text { - Monitor } \\
\end{array}$ \\
\hline \multirow[t]{3}{*}{ Grout Curtain } & Mobilization & - Site preparation \\
\hline & O\&M & $\begin{array}{l}\text { - Drill inspection holes } \\
\text { - Pump clean grout } \\
\end{array}$ \\
\hline & Closure/Post-Closure & $\begin{array}{l}\text { - D\&D equipment } \\
\text { - Monitor }\end{array}$ \\
\hline \multirow[t]{3}{*}{ Ex Situ Solidification/Stabilization } & Mobilization & $\begin{array}{l}\text { - Site preparation } \\
\text { - Excavate material } \\
\end{array}$ \\
\hline & $\mathbf{O \& M}$ & $\begin{array}{l}\text { - Feed contaminated material into } \\
\text { blending unit }\end{array}$ \\
\hline & Closure/Post-Closure & - D\&D equipment \\
\hline \multirow[t]{3}{*}{ Ex Situ Soil Washing } & Mobilization & $\begin{array}{l}\text { - Site preparation } \\
\text { - Excavate material }\end{array}$ \\
\hline & O\&M & - Soil washing \\
\hline & Closure/Post-Closure & - D\&D equipment \\
\hline \multirow[t]{3}{*}{ In Situ Solidification/Stabilization } & Mobilization & - Site preparation \\
\hline & O\&M & - Stabilize material \\
\hline & Closure/Post-Closure & $\begin{array}{l}\text { - D\&D equipment } \\
\text { - Monitor } \\
\end{array}$ \\
\hline \multirow[t]{3}{*}{ Air Stripping } & Mobilization & $\begin{array}{l}\text { - Site preparation } \\
\text { - Install monitoring wells } \\
\end{array}$ \\
\hline & O\&M & $\begin{array}{l}\text { - Operate air stripper } \\
\text { - Maintain air stripper } \\
\end{array}$ \\
\hline & Closure/Post-Closure & $\begin{array}{l}\text { - D\&D equipment } \\
\text { - Restore site } \\
\text { - Monitor/sample }\end{array}$ \\
\hline
\end{tabular}


Table 3.1-1 Activities for Various Technologies, continued.

\begin{tabular}{|c|c|c|}
\hline Technology & Phase & Activities \\
\hline \multirow[t]{3}{*}{ Ion Exchange } & Mobilization & - Site preparation \\
\hline & O\&M & $\begin{array}{l}\text { - Pretreat waste stream } \\
\text { - Operate ion exchange column } \\
\text { - Treat/dispose of waste } \\
\end{array}$ \\
\hline & Closure/Post-Closure & $\begin{array}{l}\text { - D\&D equipment } \\
\text { - Restore site } \\
\text { - Secondary treatment of waste } \\
\end{array}$ \\
\hline \multirow[t]{3}{*}{ Incineration } & Mobilization & $\begin{array}{l}\text { - Site preparation } \\
\text { - Pretreat contaminated material }\end{array}$ \\
\hline & O\&M & $\begin{array}{l}\text { - Operate incinerator } \\
\text { - Collect residuals } \\
\text { - Monitor, continuous decontamination }\end{array}$ \\
\hline & Closure/Post-Closure & $\begin{array}{l}\text { - D\&D equipment } \\
\text { - Demobilize incinerator } \\
\text { - Restore site } \\
\end{array}$ \\
\hline \multirow[t]{3}{*}{ Soil Vapor Extraction } & Mobilization & $\begin{array}{l}\text { - Site preparation } \\
\text { - Install extraction wells } \\
\text { - Install off-gas collection system } \\
\text { - Install off-gas treatment sysem }\end{array}$ \\
\hline & O\&M & $\begin{array}{l}\text { - Operate vacuum extraction unit } \\
\text { - Operate off-gas treatment system } \\
\text { - Operate monitoring system } \\
\end{array}$ \\
\hline & Closure/Post-Closure & $\begin{array}{l}\text { - D\&D equipment } \\
\text { - Close/remove extraction wells }\end{array}$ \\
\hline \multirow[t]{3}{*}{ Metal Meiting } & Mobilization & - Site preparation \\
\hline & O\&M & $\begin{array}{l}\text { - Excavate material } \\
\text { - Screen material } \\
\text { - Heat contaminated material } \\
\text { - Collect and treat off-gas } \\
\end{array}$ \\
\hline & Closure/Post-Closure & $\begin{array}{l}\text { - D\&D equipment } \\
\text { - Restore site } \\
\end{array}$ \\
\hline
\end{tabular}


Table 3.1-1 Activities for Various Technologies, continued.

\begin{tabular}{|c|c|c|}
\hline Technology & Phase & Activities \\
\hline \multirow[t]{3}{*}{ Molten Solids Processing } & Mobilization & - Site preparation \\
\hline & O\&M & $\begin{array}{l}\text { - Excavate material } \\
\text { - Screen material } \\
\text { - Inject/combine contaminant with molten } \\
\text { salt/glass } \\
\text { - Collect and treat off-gas } \\
\end{array}$ \\
\hline & Closure/Post-Closure & $\begin{array}{l}\text { - D\&D equipment } \\
\text { - Restore site } \\
\end{array}$ \\
\hline \multirow[t]{3}{*}{ Roasting } & Mobilization & $\begin{array}{l}\text { - Site preparation } \\
\text { - Mobilize equipment }\end{array}$ \\
\hline & O\&M & $\begin{array}{l}\text { - Excavate material } \\
\text { - Screen material } \\
\text { - Heat contaminated material } \\
\text { - Collect and treat off-gas } \\
\end{array}$ \\
\hline & Closure/Post-Closure & $\begin{array}{l}\text { - D\&D equipment } \\
\text { - Restore site } \\
\end{array}$ \\
\hline \multirow[t]{3}{*}{ In Situ Biodegradation } & Mobilization & $\begin{array}{l}\text { - Site preparation } \\
\text { - Drill extraction wells } \\
\end{array}$ \\
\hline & O\&M & $\begin{array}{l}\text { - Add water, oxygen, nutrients } \\
\text { - Pump from extraction wells } \\
\text { - Monitor }\end{array}$ \\
\hline & Closure/Post-Closure & $\begin{array}{l}\text { - Fillgrout wells } \\
\text { - Restore site } \\
\text { - Monitor } \\
\end{array}$ \\
\hline \multirow[t]{3}{*}{ Catalytic Destruction } & Mobilization & $\begin{array}{l}\text { - Site Preparation } \\
\text { - Excavate contaminated soil }\end{array}$ \\
\hline & O\&M & $\begin{array}{l}\text { - Screen contaminated soil } \\
\text { - Mix soil with water } \\
\text { - Separate slurry/water } \\
\text { - Treat contaminated water }\end{array}$ \\
\hline & Closure/Post-Closure & - D\&D equipment \\
\hline
\end{tabular}




\subsection{WM Modules}

WM activities are grouped as modules for the PEIS. A module comprises an essentially self-contained waste process. The WM module comprises one main waste handling and/or treatment process such as receiving or vitrification. The module serves conceptually as a "box" within which worker exposures may occur. Modules may be interchangeably arranged to form "treatment trains" containing all the processes required to treat and dispose of a specific type of waste. An example of a treatment train involving incineration of solid waste is presented by WM module (i.e., preparation, treatment, storage, disposal) in figure 3.2-1.

\begin{tabular}{|l|l|l|l|}
\multicolumn{1}{c|}{ Preparation } & \multicolumn{1}{c|}{ Treatment } \\
\hline Receiving \\
Inspection \\
Sorting
\end{tabular}

Figure 3.2-1. Example of a "Treatment Train".

Each of these modules has subactivities associated with it. Construction is a basic activity that is associated with each of the modules, but other O\&M activities are also required. Some of these subactivities are shown in table 3.2-1.

Table 3.2-1. Waste Management Activities and Subactivities

\begin{tabular}{||l|l|}
\hline \multicolumn{1}{|c|}{ Activity } & \multicolumn{1}{c|}{ Subactivity } \\
\hline Receiving/Inspection & $\begin{array}{l}\text { Unload drum, cask, or TRUPACT } \\
\text { from vehicle } \\
\text { Assay/real-time radiography } \\
\text { Temporary storage }\end{array}$ \\
\hline Sorting & Sort solid waste on conveyor \\
\hline
\end{tabular}


Table 3.2-1 WM Activities and Subactivities (continued)

\begin{tabular}{|c|c|}
\hline Activity & Subactivity \\
\hline Size reduction & $\begin{array}{l}\text { Feed waste bin } \\
\text { Shredder operation }\end{array}$ \\
\hline Supercompaction & $\begin{array}{l}\text { Supercompactor operation } \\
\text { Packaging/drum handling }\end{array}$ \\
\hline In-drum compaction & $\begin{array}{l}\text { In-drum compactor operation } \\
\text { Packaging/drum handling }\end{array}$ \\
\hline Shredding/compaction & $\begin{array}{l}\text { Feed waste bin } \\
\text { Prepare waste (shred) } \\
\text { Compaction or supercompaction }\end{array}$ \\
\hline Solidification/Stabilization & $\begin{array}{l}\text { Solidification (cement or polymer) } \\
\text { Packaging/drum handling }\end{array}$ \\
\hline Vitrification & $\begin{array}{l}\text { Vitrification } \\
\text { Packaging/drum handling }\end{array}$ \\
\hline Evaporation & Evaporator operation \\
\hline Incineration & Incinerate \\
\hline Metal Melting & $\begin{array}{l}\text { Feed waste bin } \\
\text { Prepare waste (shred) } \\
\text { Melt metals }\end{array}$ \\
\hline Grouting & Grout and seal drum \\
\hline Aqueous treatment ${ }^{b}$ & $\begin{array}{l}\text { Neutralization } \\
\text { Solid separation (filtration) } \\
\text { Metal removal } \\
\text { Wet oxidation } \\
\text { Evaporation } \\
\text { Condensation } \\
\text { Ion exchange } \\
\end{array}$ \\
\hline Packaging & Place waste in package \\
\hline Decontamination & $\begin{array}{l}\text { Prepare waste (shred) } \\
\text { Decontamination booth (high pressure } \\
\text { spray or blasting) } \\
\text { Compaction } \\
\text { Packaging/drum handling }\end{array}$ \\
\hline Mercury separation & $\begin{array}{l}\text { Feed waste bin } \\
\text { Prepare waste (shred) } \\
\text { Mercury roasting/retort }\end{array}$ \\
\hline Thermal desorption & $\begin{array}{l}\text { Feed waste bin } \\
\text { Thermal desorption }\end{array}$ \\
\hline Wet-air oxidation & Oxidation reactor operation \\
\hline
\end{tabular}


Table 3.2-1 WM Activities and Subactivities (continued)

\begin{tabular}{||l|l|}
\hline \multicolumn{1}{|c|}{ Activity } & \multicolumn{1}{c|}{ Subactivity } \\
\hline Lead recovery & $\begin{array}{l}\text { Metal melting } \\
\text { Packaging/drum handling }\end{array}$ \\
\hline Soil washing & $\begin{array}{l}\text { Scrub } \\
\text { Separate } \\
\text { Soil wash }\end{array}$ \\
\hline Sludge washing & $\begin{array}{l}\text { Extraction } \\
\text { Filtration } \\
\text { Solvent recovery }\end{array}$ \\
\hline Debris washing & Spray, wash, rinse debris \\
\hline Certification/shipping & $\begin{array}{l}\text { Assay/real-time radiography } \\
\text { Load drum, cask, or TRUPACT II on } \\
\text { vehicle }\end{array}$ \\
\hline Drum storage & Place drum(s) in storage \\
\hline Cask storage &
\end{tabular}

TRUPACT II is a transuranic package transporter II.

There may be different combinations of these aqueous treatment systems depending on the nature of the waste being treated.

c Use of either forklift or crane, depending on the nature of waste being handled.

\subsection{Worker Types}

The technologies and modules outlined in sections 3.1 and 3.2 require workers with specific skills to complete the activities. Information such as worker types and the number of hours each worker spends 
performing an activity is site-specific and usually can be obtained by consulting site personnel or engineering groups.

For ER activities, the workers evaluated include only workers in areas where contamination does or could occur. These areas are populated by remedial workers and support personnel such as health and safety personnel and supervisors. Persons not directly involved in the remediation activity are not evaluated as part of the worker risk analysis. The types of workers potentially involved in remediation activities are shown in table 3.3-1, where a number of trades are grouped into occupational categories.

For WM activities, the TSD workers evaluated include only those involved in normal operations, with the exception of those potentially exposed during an accident. These workers are potentially located in uncontrolled areas and controlled areas, such as radiation and contaminated areas. Types of workers potentially involved in waste management activities are shown in table 3.3-2. WM worker types generally include operators, managers, support personnel (e.g., health physicists, health and safety personnel), and maintenance and construction crews. 
Table 3.3-1. Examples of ER Activities and Worker Types

\begin{tabular}{|c|c|}
\hline Technology & Worker Types \\
\hline $\begin{array}{l}\text { Containment } \\
\text { Stabilization: } \\
\text { Partial Excavation } \\
\text { Injection of slurry } \\
\text { Backfill, grade }\end{array}$ & \multirow{2}{*}{$\begin{array}{l}\text { Heavy equipment operators } \\
\text { Laborers } \\
\text { Supervisor } \\
\text { Loaders/drivers } \\
\text { Health physicist (HP)/industrial hygienist (IH) } \\
\text { Safety engineer } \\
\text { Carpenters }\end{array}$} \\
\hline $\begin{array}{l}\text { Solidification: } \\
\text { Partial excavation } \\
\text { Mixing } \\
\text { Replacement } \\
\text { Backfill, grade } \\
\end{array}$ & \\
\hline $\begin{array}{l}\text { Treatment } \\
\text { Soil Excavation: } \\
\text { Excavation of overburden } \\
\text { Excavation of contaminated soil } \\
\text { Soil Dumping } \\
\text { Soil transport }\end{array}$ & $\begin{array}{l}\text { Heavy equipment operator } \\
\text { Laborers } \\
\text { Supervisor, HP, HP technicians } \\
\text { IH, safety engineer } \\
\text { Loaders, drivers } \\
\text { Carpenters }\end{array}$ \\
\hline $\begin{array}{l}\text { Soil Vapor Extraction (SVE): } \\
\text { Well drilling and installation of SVE } \\
\text { Facility operation and construction } \\
\text { Operation and maintenance } \\
\text { Sampling/monitoring }\end{array}$ & $\begin{array}{l}\text { Drilling crew (driller, helper, laborer, IH/HP) } \\
\text { Construction crew } \\
\text { Chemical technician, engineers } \\
\text { Equipment maintenance personnel } \\
\text { Environmental technician }\end{array}$ \\
\hline $\begin{array}{l}\text { Incineration: } \\
\text { Transport of mobile unit incinerator to site } \\
\text { Facility/process construction } \\
\text { Testing } \\
\text { Operation and Maintenance } \\
\text { Sampling/monitoring }\end{array}$ & $\begin{array}{l}\text { Construction crew } \\
\text { Engineers, technicians equipment maintenance } \\
\quad \text { personnel } \\
\text { Environmental technicians }\end{array}$ \\
\hline $\begin{array}{l}\text { D\&D } \\
\text { Equipment Dismantling } \\
\text { Equipment Removal } \\
\text { Equipment Decontamination } \\
\text { Transport/Packaging }\end{array}$ & $\begin{array}{l}\text { D\&D crew (radiation technician, electrician, pipe } \\
\quad \text { fitter, carpenter, welder) } \\
\text { Technicians } \\
\text { Laborers/loaders/haulers } \\
\text { IH/HP } \\
\text { Safety engineer }\end{array}$ \\
\hline
\end{tabular}


Table 3.3-2. Examples of WM Activities and Worker Types

\begin{tabular}{|l|l|}
\hline Module & \multicolumn{1}{|c|}{ Worker Types } \\
\hline Treatment & $\begin{array}{l}\text { Equipment operators (plant operators) } \\
\text { Chemical technologists } \\
\text { Health physicist } \\
\text { Maintenance (facility/equipment) } \\
\text { Construction/carpentry personnel } \\
\text { Manager, supervisor, foreman }\end{array}$ \\
\hline \multirow{5}{*}{ Storage } & Assay technicians \\
& Forklift operators \\
& Crane operators \\
& Maintenance (facility/equipment) \\
& Construction/carpentry personnel \\
& Handler, laborer, helper \\
& Equipment operators \\
& Health physicists \\
& Manager, supervisor, foreman \\
\hline & Assay technicians \\
& Field technicians \\
& Health physicist \\
& Handler, laborer, helper \\
& Crane, forklift operators \\
& Maintenance (facility/equipment) \\
& Monitoring (environmental technician) \\
& Manager, supervisor, foreman \\
\hline
\end{tabular}

Source: EG\&G 1993a.

The activities illustrated in figure 3.3-1 are waste storage and transport, which are WM activities, and radiation sampling/monitoring at a hypothetical remediation site, which is an ER activity. 


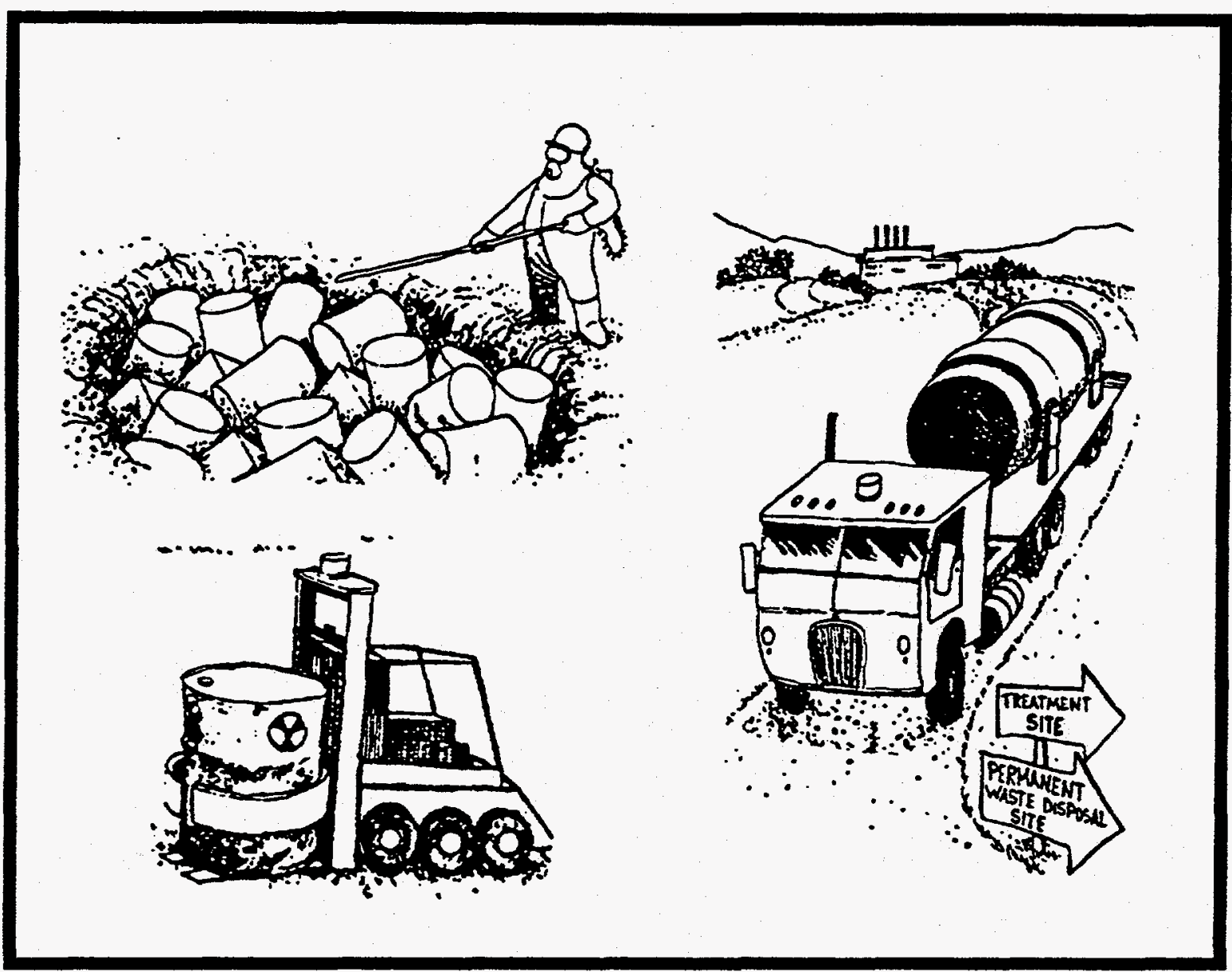

Figure 3.3-1. Example of ER and WM Worker Activities.

\subsection{Worker Exposure Conditions}

Regulatory requirements have been established to limit exposures of workers to radionuclides and hazardous chemicals. These requirements are generally considered to be conservative and to offer safe conditions to workers. Specific requirements for workers involved in hazardous waste operations and emergency response and workers performing activities involving radiation are identified in 29 CFR 1910.120, 29 CFR 1926.65, 10 CFR 835, and DOE Order 5480.11. Guidance documents such as the Occupational Safety and Health Guidance Manual for Hazardous Waste Site Activities, Standard Operating Safety Guides, and Field Standard Operating Procedures (e.g., FSOP No. 6 [EPA 1985a]) provide information oriented toward reducing exposures at hazardous waste sites. Worker exposure to 
radionuclides is regulated by 10 CFR 835 and DOE Order 5480.11. In addition, DOE installations institute their own radioactive waste operations and hazardous waste operations procedures. At DOE facilities, the "as low as reasonably achievable" (ALARA) concept is also employed, which states that exposures to radiological contaminants should be kept as low as reasonably achievable. In the Superfund arena, worker exposures are considered to be "acceptable" when they fall within or below the range of $1 \mathrm{E}$ 4 to $1 \mathrm{E}-6$.

One of the primary assumptions of this methodology is that worker exposures do not routinely exceed occupational exposure limits for remediation and WM workers. This assumption is based on historical occupational exposure data, which show that workers involved in routine operations are generally exposed to levels less than these limits. Radiation exposure limits in the DOE Radiological Control Manual (i.e., $1 \mathrm{rem} / \mathrm{yr}$ ) are assumed to be the upper bounds of worker exposure to radiation; however, exposure limits and criteria specified in 10 CFR 835, DOE Order 5480.11, and 6430.1A are useful reference points. Threshold Limit Values (TLVs) and/or recommended exposure limits (RELs) are assumed to be the upper limit of worker exposure to chemicals. In cases where exposure concentrations cannot be reliably calculated due to a lack of data, these regulatory or recommended or administrative limits can be assumed as a conservative estimate.

\subsubsection{Personal Protective Equipment}

Levels of Protection A, B, C, and D (NIOSH 1985) were developed to provide guidance on worker PPE for workers involved in Superfund cleanups. A list of PPE, shown in table 3.4-1, provides a basis for identifying PPE needs. Each ensemble should be tailored to specific situations to provide the most appropriate level for protection. The National Institute of Occupational Safety and Health (NIOSH) has published assigned protection factors (APFs) for respiratory equipment, and several documents list chemical protective equipment (CPE) permeation rates and indices (NIOSH 1990; DOE 1991a; Keith 1992).

For ER activities, worker risks are calculated for workers wearing PPE, when it is considered to be appropriate. To determine the level of respiratory protection required, the estimated air contaminant concentrations are compared to both the regulatory and administrative (or action) limits. For chemicals, if the estimated air concentration is $>50 \%$ of the TLV, the next level of protection APF is used to reduce the air concentration and to account for the higher level of protection. For radionuclides, if the estimated 
air concentration is $>10 \%$ of the DAC, the next level of protection APF is used to reduce the air concentration and to account for the higher level of protection. In the 10 CFR 835 guidelines, respiratory equipment is typically required if $10 \% \mathrm{DAC}$ is derived. This percentage can be used when site-specific information is not available. Once the air concentrations are less than this administrative limit, risks are then estimated and the level of protection is documented. Although there is always a possibility that the PPE can be ripped or that it is not sealed properly, this methodology assumes that good work practices under normal conditions prevent these occurrences. For site-specific applications it may be considered necessary to account for these events.

For routine WM activities, workers are assumed to not wear any PPE. TSD workers generally are not dressed out during their activities because TSD facilities are designed (e.g., engineering controls) not to exceed regulatory exposure limits. In addition, WM facilities often have areas that are designed for remote handling of waste during treatment or packaging of waste for shipment. Again, for site-specific applications, PPE may be required. If so, exposure assessment should account for PPE as described for ER applications. 
Table 3.4-1. Personal Protective Equipment

\begin{tabular}{|c|c|c|c|c|}
\hline $\begin{array}{l}\text { Level of } \\
\text { Protection }\end{array}$ & Equipment & $\begin{array}{l}\text { Protection } \\
\text { Provided }\end{array}$ & $\begin{array}{l}\text { Should Be } \\
\text { Used When: }\end{array}$ & $\begin{array}{l}\text { Limiting } \\
\text { Criteria }\end{array}$ \\
\hline . & $\begin{array}{l}\text { RECOMMENDED: } \\
\text { - Pressure-demand, full- } \\
\text { face piece SCBA }{ }^{a} \text { or } \\
\text { pressure-demand } \\
\text { supplied air respirator } \\
\text { with escape SCBA. } \\
\text { - Fully encapsulating, } \\
\text { chemical-resistant suit. } \\
\text { - Inner chemical-resistant } \\
\text { gloves. } \\
\text { - Chemical-resistant } \\
\text { safety boots/shoes. } \\
\text { - Two-way radio. } \\
\text { OPTIONAL: } \\
\text { - Cooling unit. } \\
\text { - Coveralls. } \\
\text { - Long cotton underwear. } \\
\text { - Hard hat. } \\
\text { - Disposable gloves and } \\
\text { boot covers. }\end{array}$ & $\begin{array}{l}\text { The highest available level } \\
\text { of respiratory, skin, and eye } \\
\text { protection. }\end{array}$ & $\begin{array}{l}\text { The chemical substance } \\
\text { has been identified and } \\
\text { requires the highest level } \\
\text { of protection for skin, } \\
\text { eyes, and the respiratory } \\
\text { system based on the } \\
\text { following: } \\
\text { Measured (or potential } \\
\text { for) high concentration of } \\
\text { atmospheric vapors, } \\
\text { gases, or particulates, } \\
\text { OR } \\
\text { Site operations and work } \\
\text { functions involving a high } \\
\text { potential for splash, } \\
\text { inmersion, or exposure } \\
\text { to unexpected vapors, } \\
\text { gases, or particulates of } \\
\text { materials that are harmful } \\
\text { to the skin or capable of } \\
\text { being absorbed through } \\
\text { the skin. } \\
\text { Substances with a high } \\
\text { degree of hazard to the } \\
\text { skin are known or } \\
\text { suspected to be present, } \\
\text { and skin contact is } \\
\text { possible. } \\
\text { Operations must be } \\
\text { conducted in confined, } \\
\text { poorly-ventilated areas } \\
\text { until the absence of } \\
\text { conditions requiring } \\
\text { Level A protection are } \\
\text { determined. }\end{array}$ & $\begin{array}{l}\text { Fully } \\
\text { encapsulating } \\
\text { suit material } \\
\text { must be } \\
\text { compatible } \\
\text { with the } \\
\text { substances } \\
\text { involved. }\end{array}$ \\
\hline
\end{tabular}

a self-contained breathing apparatus 
Table 3.4-1. Personal Protective Equipment (continued).

\begin{tabular}{|c|c|c|c|c|}
\hline $\begin{array}{l}\text { Level of } \\
\text { Protection }\end{array}$ & Equipment & $\begin{array}{l}\text { Protection } \\
\text { Provided }\end{array}$ & $\begin{array}{c}\text { Should Be Used } \\
\text { When: }\end{array}$ & $\begin{array}{l}\text { Limiting } \\
\text { Criteria }\end{array}$ \\
\hline$?$ & $\begin{array}{l}\text { RECOMMENDED: } \\
\text { Pressure-demand, } \\
\text { full-face piece SCBA } \\
\text { or pressure-demand } \\
\text { supplied air } \\
\text { respirator with } \\
\text { escape SCBA. } \\
\text { - Chemical-resistant } \\
\text { clothing (overalls and } \\
\text { long-sleeved jacket; } \\
\text { hooded, one- or two- } \\
\text { piece chemical splash } \\
\text { suit; disposable } \\
\text { chemical-resistant } \\
\text { one-piece suit). } \\
\text { Inner and outer } \\
\text { chemical-resistant } \\
\text { gloves. } \\
\text { Chemical-resistant } \\
\text { safety boots/shoes. } \\
\text { - Hard hat. } \\
\text { Two-way radio } \\
\text { communicators. } \\
\text { OPTIONAL: } \\
\text { - Coveralls. } \\
\text { Disposable boot } \\
\text { covers. } \\
\text { Face shield. } \\
\text { Long cotton } \\
\text { underwear. }\end{array}$ & $\begin{array}{l}\text { The same level of } \\
\text { respiratory protection } \\
\text { but less skin } \\
\text { protection than Level } \\
\text { A. It is the minimum } \\
\text { level recommended } \\
\text { for initial site entries } \\
\text { until the hazards have } \\
\text { been further } \\
\text { identified. }\end{array}$ & $\begin{array}{l}\text { The type and } \\
\text { atmospheric } \\
\text { concentration of } \\
\text { substances have been } \\
\text { identified and require a } \\
\text { high level of } \\
\text { respiratory protection } \\
\text { but less skin } \\
\text { protection. This } \\
\text { involves the following } \\
\text { atmospheres: } \\
\text { Atmospheres with } \\
\text { IDLH concentrations } \\
\text { of specific substances } \\
\text { that do not represent a } \\
\text { severe skin hazard; } \\
\text { OR } \\
\text { Atmospheres that do } \\
\text { not meet the criteria } \\
\text { for use of air-purifying } \\
\text { respirators. } \\
\text { Atmospheres that } \\
\text { contain less than } \\
\text { 19.5\% oxygen. } \\
\text { The presence of } \\
\text { incompletely identified } \\
\text { vapors or gases is } \\
\text { indicated by direct } \\
\text { reading of organic } \\
\text { vapor detection } \\
\text { instruments, but vapors } \\
\text { and gases are not } \\
\text { suspected of containing } \\
\text { high levels of } \\
\text { chemicals harmful to } \\
\text { skin or capable of } \\
\text { being absorbed through } \\
\text { the intact skin. } \\
\text { - }\end{array}$ & $\begin{array}{l}\text { Use only when } \\
\text { vapor or gases } \\
\text { present are not } \\
\text { suspected of } \\
\text { containing high } \\
\text { concentrations } \\
\text { of chemicals } \\
\text { that are harmful } \\
\text { to skin or } \\
\text { capable of being } \\
\text { absorbed } \\
\text { through the } \\
\text { intact skin. } \\
\text { Use only when } \\
\text { it is highly } \\
\text { unlikely that the } \\
\text { work being } \\
\text { done will } \\
\text { generate either } \\
\text { high } \\
\text { concentrations } \\
\text { of vapors, } \\
\text { gases, or } \\
\text { particulates or } \\
\text { splashes of } \\
\text { material that } \\
\text { will affect } \\
\text { exposed skin. }\end{array}$ \\
\hline
\end{tabular}

${ }^{b}$ immediately dangerous to life or health. 
Table 3.4-1. Personal Protective Equipment (continued).

\begin{tabular}{|c|c|c|c|c|}
\hline $\begin{array}{l}\text { Level of } \\
\text { Protection }\end{array}$ & Equipment & $\begin{array}{l}\text { Protection } \\
\text { Provided }\end{array}$ & $\begin{array}{c}\text { Should Be Used } \\
\text { When: }\end{array}$ & Limiting Criteria \\
\hline & $\begin{array}{l}\text { RECOMMENDED: } \\
\text { - Full-face piece, air- } \\
\text { purifying, canister- } \\
\text { equipped respirator. } \\
\text { - Chemical-resistant } \\
\text { clothing (overalls and } \\
\text { long-sleeved jacket; } \\
\text { hooded, one- or two- } \\
\text { piece chemical splash } \\
\text { suit; disposable } \\
\text { chemical-resistant one- } \\
\text { piece suit). } \\
\text { - Inner and outer } \\
\text { chemical-resistant } \\
\text { gloves. } \\
\text { - Chemical-resistant } \\
\text { safety boots/shoes. } \\
\text { - Hard hat. } \\
\text { Two-way radio } \\
\text { communicators. } \\
\text { OPTIONAL: } \\
\text { - Coveralls. } \\
\text { Disposable boot } \\
\text { covers. } \\
\text { - Face shield. } \\
\text { Escape mask. } \\
\text { Long cotton } \\
\text { underwear. }\end{array}$ & $\begin{array}{l}\text { The same level of } \\
\text { skin protection as } \\
\text { Level B but a lower } \\
\text { level of respiratory } \\
\text { protection. }\end{array}$ & $\begin{array}{l}\text { The same } \\
\text { atmospheric } \\
\text { contaminants, } \\
\text { liquid splashes, or } \\
\text { other direct } \\
\text { contact will not } \\
\text { adversely affect } \\
\text { any exposed skin. } \\
\text { The types of air } \\
\text { contaminants } \\
\text { have been } \\
\text { identified, } \\
\text { concentrations } \\
\text { have been } \\
\text { measured, and a } \\
\text { canister that can } \\
\text { remove the } \\
\text { contaminant is } \\
\text { available. } \\
\text { All criteria for } \\
\text { the use of air- } \\
\text { purifying } \\
\text { respirators are } \\
\text { met. }\end{array}$ & $\begin{array}{l}\text { - Atmospheric } \\
\text { concentration of } \\
\text { chemicals must not } \\
\text { exceed IDLH } \\
\text { levels. } \\
\text { The atmosphere } \\
\text { must contain at } \\
\text { least } 19.5 \% \\
\text { oxygen. }\end{array}$ \\
\hline & $\begin{array}{l}\text { RECOMMENDED: } \\
\text { Coveralls. } \\
\text { - Safety boots/shoes. } \\
\text { - Safety glasses or } \\
\text { chemical splash } \\
\text { goggles. } \\
\text { - Hard hat. } \\
\text { OPTIONAL: } \\
\text { - Gloves. } \\
\text { - Escape mask. } \\
\text { - Face shield. }\end{array}$ & $\begin{array}{l}\text { No respiratory } \\
\text { protection. Minimal } \\
\text { skin protection. }\end{array}$ & $\begin{array}{l}\text { The atmosphere } \\
\text { contains no } \\
\text { known hazard. } \\
\text { Work functions } \\
\text { preciude splashes, } \\
\text { immersion, or the } \\
\text { potential for } \\
\text { unexpected } \\
\text { inhalation of or } \\
\text { contact with } \\
\text { hazardous levels } \\
\text { of any chemicals. }\end{array}$ & $\begin{array}{l}\text { - This level should } \\
\text { not be worn in the } \\
\text { Exclusion Zone. } \\
\text { - The atmosphere } \\
\text { must contain at } \\
\text { least } 19.5 \% \\
\text { oxygen. }\end{array}$ \\
\hline
\end{tabular}

Source: NIOSH 1985; OSHA 29 CFR 1910.120. 


\section{EXPOSURE ESTIMATION}

Exposure is defined as the contact of an organism with a chemical or physical agent. The magnitude of exposure is determined by measuring or estimating the amount of the agent at an exchange boundary (i.e., the lungs, gut, skin) during a specified time period. Exposure estimation is based on the magnitude, frequency, duration and route of exposure. The objective of exposure estimation is to characterize the type and magnitude of exposures to contaminants of concern, their byproducts (degradation and radionuclide progeny), and products of combustion that are associated with a site or TSD facility. The exposure estimation proceeds through the following steps:

- Characterization of worker populations (potential receptors)

- Identification of exposure pathways

- Quantification of exposure.

This methodology follows the general principles outlined in the EPA Exposure Assessment Methods Handbook (EPA 1989b) and in other EPA guidance (EPA 1989a, 1988a). While the Agency for Toxic Substances and Disease Registry (ATSDR) Public Health Assessment Guidance Manual follows another outline for presentation of health assessments, the format of RAGS was considered to be more advantageous for the programmatic elements of this methodology.

The first step in evaluating exposure is to identify the worker population on or near the work site. The output of this first step is a qualitative evaluation of the worker population with emphasis on those characteristics that influence exposure. All information gathered in this step supports the identification of exposure pathways.

The second step of exposure estimation is the identification of exposure pathways. An exposure pathway describes a unique mechanism by which an individual or population is exposed to contaminants or physical agents at or originating from a site or facility. Each exposure pathway must include a source or release from a source, an exposure point, and an exposure route. If the exposure point differs from the source, the exposure pathway must also include a transport medium (e.g., air) or media (in cases of intermedia transfer). Exposure pathways may be of three types: potential, completed, or eliminated. A potential 
pathway is an exposure pathway that is being considered for analysis. A potential pathway is based on the likelihood of the existence of exposure routes and linkages between environmental media. A complete exposure pathway links the source, location, and type of environmental releases with the population location and activity patterns. A complete exposure pathway consists of the following elements:

- A source with a mechanism for release of contaminants

- A transport medium (environmental medium through which contaminants are transported)

- An exposure route (e.g.,ingestion, inhalation, direct radiation) by which receptors come into contact with contaminants

- An exposure point

- A potential receptor.

An eliminated pathway is an exposure pathway that has undergone preliminary analysis and has been found to be incomplete (i.e., one or more of the elements comprising a complete pathway is absent). For ER workers, the level of PPE used may eliminate some exposure pathways by producing demonstrable protection from exposure. Statistics on PPE failure are not readily available; however, it is unreasonable to assume that PPE failure will always occur. For a site-specific analysis, the user may use specific PPE failure data if available.

The third step of exposure estimation involves quantification of exposure for the individual workers and worker populations and exposure pathways selected for quantitative evaluation. This step is conducted by identifying exposure scenarios and quantifying pathway-specific intakes or doses (EPA 1989a). The following subsections provide a brief discussion of the control and treatment technologies that may affect worker health via certain exposure pathways.

\subsection{Characterization Of Potential Receptors}

Characterization of potential receptors requires data on the number and types of workers involved in a remediation or waste management activity, potential exposure durations and frequencies, distances of receptors from the source, and protective factors. The number and types of workers involved in an activity are site-specific and technology-specific. Estimates of trends or historical data can usually be obtained by contacting site personnel involved with industrial hygiene, personnel monitoring programs, remediation 
management, or waste management facility operation. Exposure durations and frequencies can be obtained from similar sources. In the absence of specific exposure duration information, workers can be generally assumed to have an exposure duration of $8 \mathrm{hr} / \mathrm{d}$ for $5 \mathrm{~d} / \mathrm{wk}$ for $50 \mathrm{wk} / \mathrm{yr}$.

Receptor characterization also involves determination of the appropriate protective measure to be used. As described in chapter 3, different activities for ER workers may require various levels of PPE to limit the doses or intakes of contaminants by workers. In addition, protective measures such as limiting the exposure frequencies are often employed. Exposure frequencies are determined by the type of work that is being performed since work shifts may differ depending on the activities being performed. Documents from OSHA, NIOSH, and DOE are potential sources of such information.

The distance of receptors from the source is also important information when characterizing receptors. If a worker is within the cab of a bulldozer, which provides shielding and which may be located several feet above the source, the worker is less likely to be directly exposed to contaminants on the site surface than a worker standing directly on top of the contaminated site (however, the worker in the bulldozer may be exposed indirectly, by inhaling aerosolized dusts). Receptor distances and locations are part of what is known as the source-receptor configuration. Site personnel supervisors assigned to specific operations should be contacted when possible to obtain information about source-to-receptor distances and receptor locations. If such information is unavailable, professional judgement must be used to determine a reasonable site or facility configuration.

General patterns of potential receptor behavior that affect exposure pathways should be noted. For example, workers at a given site generally do not drink the groundwater from that site. Alternative drinking water sources are assumed to be supplied to them. Unlike potential offsite public receptors, workers are not assumed to ingest contaminated crops that may be grown on the site, nor do they eat meat or dairy products that have been contaminated by irrigation with contaminated water or deposition of contaminants from the atmosphere. Unless workers are directly involved with remediation of groundwater or surface water, workers are not in contact with either of these media, and because of PPE, exposure to groundwater and surface water is often limited. Such behavior patterns and assumptions limit the possible exposure pathways that could be considered for workers. 


\subsection{Identification Of Exposure Pathways}

Exposure pathways involve the transport of gases, liquids, and particulate solids within and across media such as air, water, and soil. The pathway provides a description of the mechanism by which an individual or population is exposed to a contaminant at a site. For example, a surface soil exposure pathway might be represented as follows: source $\rightarrow$ surface soil $\rightarrow$ air - inhalation. In this example, a source such as a spill containing volatile organics can contribute to contamination of the surrounding surface soil. Once in the surface soil, the VOCs are capable of volatilizing to the atmosphere, where they are available for inhalation by a worker on or nearby the contaminated site.

For an exposure pathway to be considered complete, one must be able to trace the transport of contaminants through the environment from the source of contamination to the receptor(s). It is necessary to eliminate incomplete exposure pathways from the evaluation process. A conceptual model (CM) illustrating transport media and exposure route relationships at a site can serve as a tool to determine whether or not exposure pathways are complete.

Other significant "exposures" associated with remedial actions, such as noise, heat stress, and silica, may also be considered as part of a worker risk assessment. This methodology documents methods for estimating hazards from heat stress (chapter 9); however, the other exposures are not considered quantitatively. The authors recognize the potential for additional health effects such as these; however, for screening or installation-wide analyses, these effects will likely be of less concern relative to other safety-related and exposure-related risks. For more site-specific analyses, users of this methodology may wish to consult the literature for methods for evaluating additional exposures.

\subsubsection{IDENTIfication Of Transport Media}

Transport media, or environmental media through which contaminants travel, must be determined in order to identify exposure pathways. The following transport media are considered in estimating health risks: 
- Air

- Surface soil

- Subsurface soil

- Groundwater

- Surface water

- Contaminated biota.

The worker health risk evaluation methodology considers only certain aspects of each of these transport media as they relate to remediation and TSD alternatives. Exposure to groundwater and surface water probably does not contribute significantly to the overall exposure of workers to contaminants (except when groundwater and surface water are being treated) since remédiation workers do not consume this water and they are generally protected from contact with it by wearing PPE.

The surface soil transport medium may transport vapor phase chemicals (via volatilization) or particulate contaminants from surface soil to air where they may be inhaled or ingested. Contaminants in soil can also be inadvertently absorbed through the skin as a result of dermal contact with soil. Subsurface and surface soil are potential transport media for contaminants to reach groundwater and/or surface water; however, these two media are generally not considered in this capacity for the worker risk assessment.

\subsubsection{IDENTIFICATION OF EXPOSURE ROUTES}

Exposure routes are the mechanisms by which receptors come into contact with contaminants. Contaminants can be transported through environmental media to an exposure point of contact, whereby they are taken into organisms, in this case, ER or WM workers. The exposure routes included in the worker health risk evaluation are as follows:

- Inhalation. Chemicals or radionuclides transported via air may be inhaled by receptors. Internal exposure to radionuclides from inhalation or ingestion is considered differently than external exposure to radiation. The daily dose for radionuclides and intake for chemicals is estimated using average inhalation rates for workers at varying levels of activity. An activity level can be considered light, moderate, or heavy, each requiring different inhalation rates. 
- Soil ingestion. Contaminated soil is assumed to be ingested during certain specific worker activities. The ingestion rate is based on an adult ingestion of soil and dust associated with outdoor activities. Indoor activities are assumed to have a lower ingestion rate associated with them.

- External exposure to radiation. Gamma-emitting radionuclides in soil or on/in other contaminated materials (e.g., structures, equipment, waste) are potential sources of external radiation exposure.

Dermal contact with contaminated media may also be considered a potential worker exposure route; however, for routine applications of this methodology, it is assumed that the dermal contact route is not a dominant exposure route due to the use of PPE and safe working practices. Dermal contact might become a more probable exposure route for nonroutine exposures; however, for site-specific analyses, the risk assessor, industrial hygienist, or health physicist should evaluate the pathway and make a site-specific decision. At the programmatic level, the analysis should concentrate on the more major pathways, which produce greater relative risks. At a site-specific level, greater detail could be used, particularly if there is a reasonable possibility that the dermal pathway is of major concern. Information on performing dermal exposure assessments can be found elsewhere (EPA 1989a). In addition, ocular exposure may sometimes be of concern; however, this pathway was omitted from the programmatic analysis.

Exposure routes must be determined on a site-specific and technology-specific basis. Typical remediation technologies and the exposure routes potentially affected by each technology are illustrated in table 4.2-1. For example, remedial activities such as excavation likely involve exposure routes such as inhalation, ingestion, and direct radiation. WM activities and the exposure routes affected by each activity are listed in table 4.2-2. 
Table 4.2-1. Examples of Exposure Routes for Remediation Technologies

\begin{tabular}{|c|c|c|c|}
\hline Technology & Inhalation & Ingestion & $\begin{array}{c}\text { Direct } \\
\text { Radiation }\end{array}$ \\
\hline Capping & $x^{2}$ & $\mathbf{x}$ & $x$ \\
\hline Stabilization & $\pi$ & & $x$ \\
\hline Monitoring & $\mathbf{x}$ & & $x$ \\
\hline Excavation & $\mathbf{x}$ & $x$ & $x$ \\
\hline Solidification & $\mathbf{x}$ & (x) & $\mathbf{x}$ \\
\hline Pump and Treat & $\mathbf{x}$ & & $x$ \\
\hline Soil Vapor Extraction & $x$ & & $(x)$ \\
\hline Chemical Treatment & $x$ & & (x) \\
\hline $\begin{array}{l}\text { Physical Treatment } \\
\text { Evaporation } \\
\text { In situ vitrification } \\
\text { In situ biotreatment }\end{array}$ & $\begin{array}{c}x \\
(x) \\
x\end{array}$ & $(x)$ & $\begin{array}{c}(\mathrm{x}) \\
\mathbf{x} \\
(\mathrm{x}) \\
\end{array}$ \\
\hline
\end{tabular}

" Exposure routes marked with an " $x$ " indicate that route is applicable to the corresponding technology; Direct

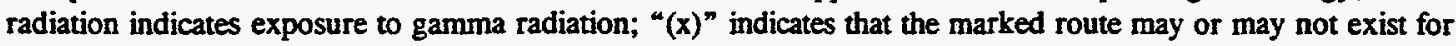
a given technology. 
Table 4.2-2. Examples of Exposure Routes for WM Activities

\begin{tabular}{||c|c|c|c|}
\hline \multicolumn{1}{|c|}{ Activity } & Inhalation & Ingestion & $\begin{array}{c}\text { Direct } \\
\text { Radiation }\end{array}$ \\
\hline $\begin{array}{l}\text { Transport: } \\
\text { Package handling }\end{array}$ & $\mathrm{x}^{\mathrm{a}}$ & $(\mathrm{x})$ & $\mathrm{x}$ \\
$\begin{array}{l}\text { Treatment: } \\
\text { Liquid waste treatment } \\
\text { (ion exchange) }\end{array}$ & $\mathrm{x}$ & $(\mathrm{x})$ & $\mathrm{x}$ \\
$\begin{array}{l}\text { Consolidation } \\
\text { Solid waste treatment } \\
\text { (e.g., solidification, } \\
\text { incineration) }\end{array}$ & $\mathrm{x}$ & $(\mathrm{x})$ & $\mathrm{x}$ \\
Storage: & $\mathrm{x}$ & $(\mathrm{x})$ & $\mathrm{x}$ \\
Assay & & & $\mathrm{x}$ \\
Package handling & & & $\mathrm{x}$ \\
Monitoring & $(\mathrm{x})$ & & $\mathrm{x}$ \\
Disposal: & $(\mathrm{x})$ & & $\mathrm{x}$ \\
Disposal & & & \\
Site maintenance & & & \\
Monitoring & & & \\
\hline
\end{tabular}

${ }^{a}$ Exposure routes marked with an " $x$ " indicate that route is applicable to the corresponding technology; Direct radiation indicates external exposure to gamma radiation; “ $(x)$ " indicates that the marked route may or may not exist for a given technology.

${ }^{b}$ External exposure to radiation depends on the waste type being handled. Hazardous waste, for example, does not present an external exposure hazard, but low-level or transuranic waste does.

\subsubsection{ConCEPTUAL MOdel}

A CM is a schematic that aids the exposure assessment by illustrating transport media and exposure route scenario relationships at a site or facility. A CM is used to develop an understanding of a site or facility's potential risk to human health and the environment. More importantly, a CM serves as a tool to help eliminate incomplete pathways from a risk assessment by qualitatively and conceptually evaluating whether exposure pathways are complete. The $\mathrm{CM}$ identifies which pathways to evaluate and data gaps that must be filled in order to evaluate a potential pathway. Figure 4.2-1 depicts an example conceptual schematic for exposure that may occur during implementation of an ER containment action at a site. 
Identification of transport media and exposure routes is part of the conceptual model development process.

The CM includes the following information:

- Known and suspected sources of contamination. Open barrels or tanks, waste piles, and contaminated surface soil are examples of contamination sources. Sources have generally been determined before the workers become involved in activities at a site or facility. In addition, it has generally been determined which sources are part of the release site. Workers at a site focus on one particular task or activity as specified by site work plans developed before additional workers are called on the scene.

- Types of contaminants and affected media. The contaminants in sources or the environment at a site or treatment facility, contaminant properties, and the media in which contaminants occur must be determined. It is important to identify contaminant types because contaminant groups react differently in the environment (e.g., if VOCs are present, they may volatilize when disturbed by excavation activities or high temperature treatment processes). A medium contaminated from a past release can be the contaminant source for other media; therefore, identifying affected past, present and future media is important.

- Known and potential routes of migration. Environmental media may transport contaminants. Sources of contaminant migration include the atmosphere, surface soil, and groundwater in cases where groundwater is being treated or extracted. After a chemical is released into the environment, it may be transported through the atmosphere, physically transformed (e.g., volatilization or precipitation), chemically transformed, or biologically transformed.

- WM-specific information. WM workers located inside facilities may be exposed to contaminants during TSD activities such as waste handling and treatment processes. Inhalation exposure may occur from contaminated air inside treatment and handling areas of facilities due to fugitive emissions and resuspended surface contamination from waste packages. Potential direct exposure may occur from radioactive waste and from containers of waste from waste handling, treatment operations, and disposal. 


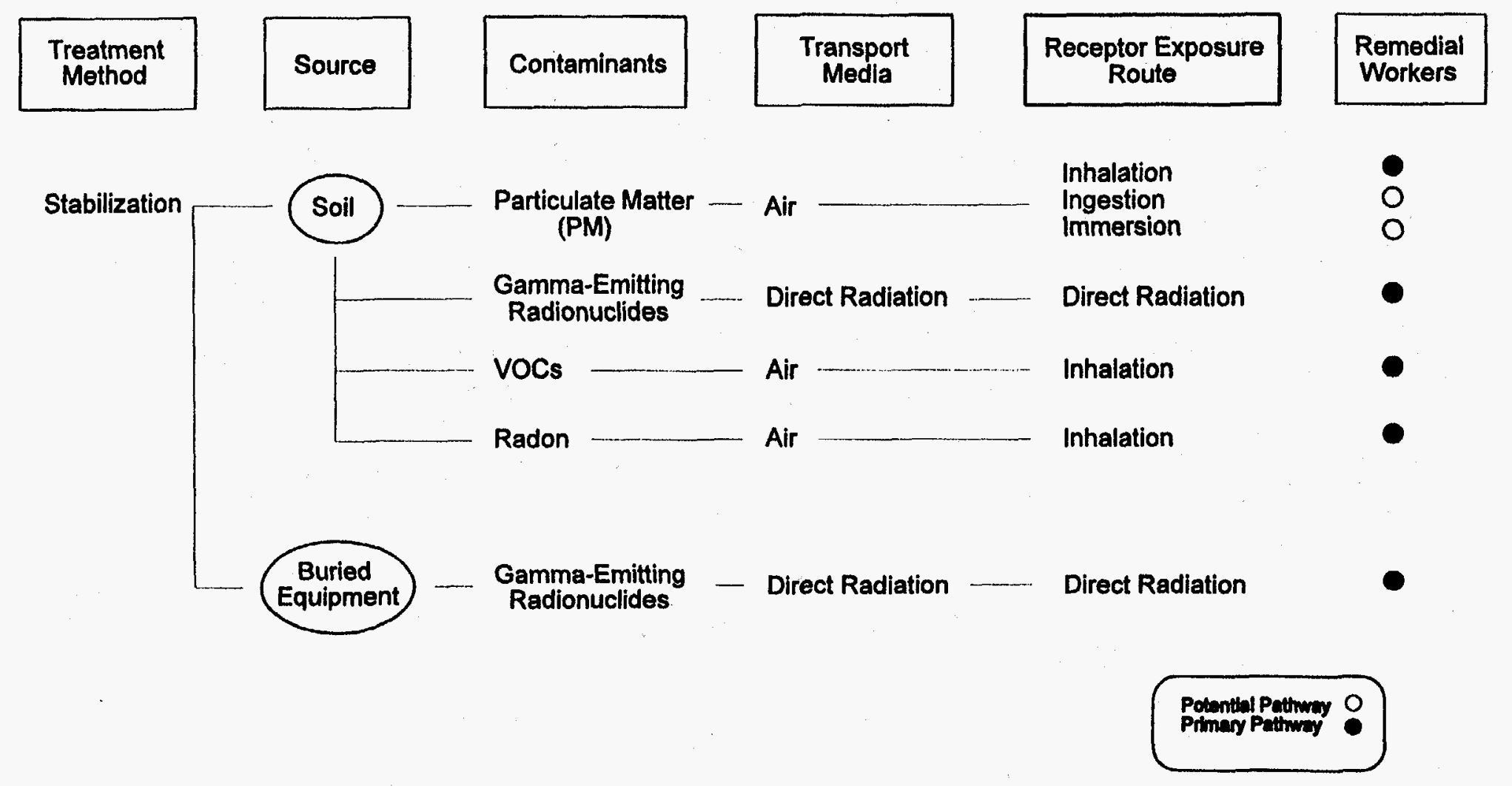

Figure 4.2-1. Example Representation of an ER Conceptual Model. 
- Known or potential receptors. An exposure pathway must have a receptor to be complete. Any point of potential contact with contaminated media is an exposure point. After contaminated or potentially contaminated media have been identified, exposure points should be identified by determining if and where any of the potentially exposed populations can contact these media through an exposure route (such as ingestion, inhalation, or direct radiation).

When complete pathways are determined, those pathways that require further evaluation should be selected. All complete pathways should be selected for further evaluation unless sound justification can be made for their omission. Absence of data or insufficient data are acceptable reasons for eliminating an exposure pathway from the quantitative evaluation; however, the impacts of omitting an exposure pathway from the risk assessment should still be addressed qualitatively. Based on such qualitative information, risk managers can then decide whether further sampling and data are warranted in a subsequent analysis. Accompanying a CM should be text that justifies why a pathway is eliminated, clearly stating the problem and the data needed to resolve it. Such text serves as a record of assumptions for a pathway.

Potential sources of contamination, exposure routes, transport media, and contaminants for both ER and WM activities are summarized in table 4.2-3. This table serves as a "summary conceptual model" for the worker risk evaluation and shows general trends in worker activities. During the risk evaluation, sitespecific and technology-specific conceptual models are developed for each remediation or TSD activity. Since each activity occurs under different circumstances, these individual conceptual models may show parameters different than the general parameters presented in table 4.2-3. 
Table 4.2-3. Summary Conceptual Model for ER and WM Activities

\begin{tabular}{|c|c|c|c|c|c|}
\hline Method & Source & Contaminants & Transport & Exposure Route & $\begin{array}{l}\text { Likelihood of } \\
\text { Completion }\end{array}$ \\
\hline WM Storage & $\begin{array}{l}\text { Resuspended surface } \\
\text { contamination from } \\
\text { waste containers } \\
\text { Waste }\end{array}$ & $\begin{array}{l}\text { VOCs, particulates } \\
\text { gamma-emitting } \\
\text { radionuclides }\end{array}$ & $\begin{array}{l}\text { air } \\
\text { direct radiation }\end{array}$ & $\begin{array}{l}\text { inhalation } \\
\text { dermal absorption } \\
\text { direct radiation }\end{array}$ & 8 \\
\hline WM Disposal & Waste & $\begin{array}{l}\text { gamma-emitting } \\
\text { radionuclides }\end{array}$ & direct radiation & direct radiation & $\bullet$ \\
\hline $\begin{array}{l}\text { ER Control } \\
\text { (Containment) }\end{array}$ & Soil & $\begin{array}{l}\text { particulates, VOCs } \\
\text { gamma-emitting } \\
\text { radionuclides }\end{array}$ & $\begin{array}{l}\text { air } \\
\text { direct contact } \\
\text { direct radiation }\end{array}$ & $\begin{array}{l}\text { inhalation } \\
\text { ingestion } \\
\text { dermal absorption } \\
\text { direct radiation }\end{array}$ & 8 \\
\hline $\begin{array}{l}\text { ER and WM } \\
\text { Treatment }\end{array}$ & $\begin{array}{l}\text { Emissions from } \\
\text { treatment and } \\
\text { fugitive emissions } \\
\text { Treatment byproduct } \\
\begin{array}{l}\text { Contaminated } \\
\text { equipment }\end{array} \\
\end{array}$ & $\begin{array}{l}\text { particulates, VOCs } \\
\text { particulates, VOCs } \\
\text { gamma-emitting } \\
\text { radionuclides } \\
\end{array}$ & $\begin{array}{l}\text { air } \\
\text { direct contact } \\
\text { air } \\
\text { direct radiation }\end{array}$ & $\begin{array}{l}\text { inhalation } \\
\text { ingestion } \\
\text { inhalation } \\
\text { ingestion } \\
\text { dermal absorption } \\
\text { direct radiation }\end{array}$ & $\begin{array}{l}8 \\
0 \\
0 \\
0 \\
0\end{array}$ \\
\hline
\end{tabular}

a symbolizes primary or likely exposure route; $O$ symbolizes potential or less likely exposure route. 


\subsection{Identification Of Exposure Scenarios}

A worker's activities and the frequency and duration of those activities make up the exposure scenario for a given pathway and determine the magnitude of that worker's exposure to contaminants and, consequently, the magnitude of risk. Within the context of the exposure scenario, the following information is integrated:

- The physical characteristics of the waste material or contaminated area of the environment (e.g., atmospheric data including wind speed, stability, temperature, and wind direction; location of contaminants; ventilation rates; and room volume),

- The activity patterns (frequencies and durations of exposure) of the exposed individuals and physical characteristics of operations at the site or facility,

- Chemical-specific information (contaminant concentrations in waste and environmental media, bioconcentration factors and partitioning coefficients that characterize the individual contaminants) (EPA 1989a).

\subsubsection{ER EXPOSURE SCENARIOS (ROUTINE OPERATIONS)}

ER exposure scenarios involve routine implementation of remediation technologies and can involve nonroutine conditions (section 4.3.3). Exposure scenario information is site-specific and technologyspecific. For ER activities, each remedial alternative requires specific activities to remediate the release sites. The ER program consists of both site remedial actions and D\&D activities. These activities are discussed in more detail in the following sections.

\subsubsection{Remedial Actions}

The types of workers and activities potentially involved in remediation activities are identified in chapter 3. For each activity evaluated, consultation with site personnel and/or an engineering team is required to 
determine site-specific information such as the number and location of workers as well as the job duration.

Each activity involves site- and technology-specific types and numbers of remediation workers and different person-hrs required to complete the tasks. For example, the activity of covering a site with rough grade fill may require six workers (four laborers and two heavy equipment operators) working for a duration of $40 \mathrm{hrs}$ to complete the covering. The worker type and exposure duration is important in determining the doses and intakes of the remediation workers during the activities. The crew sizes used to perform a worker risk assessment should be selected on a project- and activity-specific basis depending on many factors, including but not limited to (1) length of construction season, (2) weather conditions, (3) availability of equipment, and (4) materials and labor. For the PEIS application of this methodology, crew sizes used for the worker risk assessments represent only one possible crew size and exposure scenario despite the large number of conditions that exist in reality. This limitation is inherent in performing a programmatic-level risk evaluation.

\subsubsection{Decontamination And Decommissioning (Routine Operations)}

Decommissioning is the removal of a facility from service and the disposal of all hazardous materials (radioactively and nonradioactively contaminated) in excess of levels that would permit release of the building for a selected land use (e.g., unrestricted use, industrial use). D\&D encompasses the caretaking of surplus facilities, their decontamination, and their potential dismantlement and removal (DOE 1991b).

D\&D operations include numerous, site-specific activities such as surveillance and maintenance, assessment and characterization, environmental review, engineering, and closeout. D\&D activities might include entombment of reactors or other contaminated equipment; dismantling equipment and structures; removal of contaminated materials from the site; decontamination of materials involving abrasive blasting, highpressure water blasting, or washing; and routine activities such as excavation if the D\&D structure is underground. Although D\&D activities may address soil and groundwater contamination, most D\&D activities involve facilities such as reactors, hot cells, processing plants, storage tanks, cyclotrons, laboratories, support facilities, and other structures from which there have been no known releases. The extent to which a facility undergoes D\&D depends upon the ultimate goal for the facility's use. Facilities may be decontaminated, renovated, and released for uses other than their original use, decontaminated and used for their original purpose, or decontaminated and destroyed completely. Renovation activities, which 
occur if a building is to be decontaminated and used again, might include removal of a portion of a concrete or wood structure, carpentry, plumbing, or painting.

The debris remaining after the destruction of a building may constitute uncontaminated waste, RCRA waste, radioactive waste, or mixed waste. Disposal and handling of each of the contaminated wastes are regulated by federal and state laws. Activities involving the management of debris from the destruction of a building are considered WM activities.

\subsubsection{WM EXPOSURE SCENARIOS (ROUTINE OPERATIONS)}

WM exposure scenarios involve routine implementation of waste treatment technologies and storage and disposal activities and can also involve nonroutine conditions (section 4.3.3). Exposure scenario information is usually facility- and process-specific. For the PEIS, WM facility exposure scenarios are based on "generic" facility module designs, assuming that a given WM facility type is the same (except for capacity) regardless of location. For WM TSD activities, each TSD option requires specific activities to manage a given waste type. WM activities include waste handling (e.g., drum transportation), and waste treatment (e.g., incineration, solidification, or ion exchange), and waste disposal (e.g., tumulus, shallow land burial, belowground vault). The size of the workforce required to perform specific WM activities is dependent on facility size and waste processing rates. Worker numbers may be estimated based on new facility designs or on historical information.

Identification of the types of workers involved in each activity, the types of hazards to which these workers may be exposed, exposure duration, and distances from harmful substances to the worker (source-toreceptor distances) are required for quantification of exposure (see chapter 3). WM workers perform waste handling and treatment activities throughout the TSD process. For example, the following activities may be required for WM workers handling high-level waste (HLW) at a particular installation where HLW is stored:

- Construction of TSD facilities,

- Surveillance during current storage of HLW,

- Retrieval of HLW from storage,

- Treatment of HLW,

- Placement of treated HLW in canisters, 
- Storage of treated HLW until disposal.

Each of these primary activities can then be broken down into subactivities. For example, retrieval of HLW from storage after treatment might entail receipt of the transport casks, loading the cask with HLW, placement of the cask lid, decontamination and surveillance of the cask, and transfer of the cask to the transport vehicle. Each of these subactivities involves different types and numbers of WM workers and varying amounts of time required to complete the tasks. The exposure duration is important in determining the dose and the exposures of the WM workers during the activities.

\subsubsection{NONROUTINE SCENARIOS}

In addition to routine exposures and hazards faced by remediation and TSD workers during site remediation and TSD activities, workers may also be exposed to contaminants and safety-related hazards during nonroutine conditions. Nonroutine events are usually of short duration and may include such incidences as fires, equipment failure, and structural collapses.

The primary types of nonroutine events that are evaluated for WM workers are operational and severe external events. Operational events are those that result from processes and activities involved in operating the facility and may include a wide range of nonroutine events with potentially adverse consequences to the workers. In the PEIS, these events include fires propagating to the filtration systems of treatment facilities, explosions in treatment facilities, and handling events. Handling events occur when moving containers to and from storage facilities. External events include earthquakes leading to fires and explosions in treatment and storage facilities and aircraft crashes at treatment and storage facilities.

The critical parameters for assessing exposure and risks attributed to nonroutine events are conditionspecific exposure durations, amount of contaminant released during the event (e.g., amount estimated to volatilize during a fire or explosion), dimensions of the area in which the event occurs, worker configurations relative to the release, shielding information, equipment (e.g., filters) failure data, and distances of workers from the event scene.

The workers evaluated are those that are immediately involved in the event, such as a forklift operator or waste handler who dropped the waste container, and those workers who are in the vicinity of the event when it occurs. One shift of workers may be assumed to be in the facility when the event occurs. 


\subsection{Quantification Of Exposure}

Exposure analysis provides estimates of the individual dose and/or intake for each contaminant. Two types of doses are calculated. For chemical contaminants, the intake is expressed as the concentration of contaminant ( $\mathrm{mg} / \mathrm{kg} / \mathrm{d}$ ) that is inhaled, absorbed, or ingested daily by a member of the worker population. For radioactive contaminants, the dose is expressed as the effective dose equivalent (EDE). EDEs are used to normalize radiation doses and effects on a whole body basis, rather than on an individually affected organ or tissue basis. The EDE is the sum of the product of a selected target organ dose equivalent (DE) and its appropriate weighting factor. Chapters 5 and 6 present a discussion of exposure routes and calculation of intakes and doses from chemicals and radionuclides. 


\section{ESTIMATION OF CHEMICAL INTAKES}

Chemicals exist in waste material and environmental media as gases, liquids, and solids. Chemicals produce a variety of different health effects in exposed organisms, and exposure to a mixture of chemicals can produce health effects that differ from those caused by individual chemicals in the mixture. ATSDR produces toxicological profiles for chemicals commonly found at hazardous waste sites and throughout the environment as a result of waste-related activities. NIOSH is also an excellent source of occupationalrelated data. These toxicological profiles, along with toxicologists, are good resources to determine potential health effects that may result from exposure to chemicals.

For the worker risk evaluation, exposure to chemicals potentially can occur through two primary exposure routes, inhalation and ingestion. Although workers may be exposed to chemicals via dermal contact, this exposure route is not considered in the worker risk evaluation methodology, but see section 4.2.2 for more information on this exposure route. Actual exposure data are always more accurate and should be used whenever available, especially for site-specific assessments. However, when conducting assessments such as screening or installation-wide analyses, actual exposure data often are unavailable, and alternate methods of estimating intakes and/or doses must be used. In the absence of actual exposure monitoring data or known air concentration data, estimation of chemical intakes via the inhalation exposure route may require the use of point or area source models for outdoor releases or a room model for indoor releases of chemicals.

Air concentration estimation methods and methods to estimate ingestion and inhalation intake of particulates, volatiles, and gases are presented in the following subsections for assessments that must use best available data rather than actual monitoring data, industrial hygiene surveys, or known air concentrations. 


\subsection{Inhalation Route}

For ER activities, the inhalation route involves the transport of contaminants from the soil to air, water to air, or subsurface soil to air. For WM activities, the inhalation route involves transport of contaminants to the work space air through fugitive emissions during waste treatment processes and through resuspension of surface contamination during handling activities. In the quantification of worker exposure to contaminants via inhalation, contaminant air concentrations and exposure information such as exposure duration, exposure frequency, inhalation rates, body mass, and averaging time are used to estimate intake values. Activities that may require investigation of the inhalation route are shown in tables 4.3-1 and 4.3-2. Many ER and WM activities may involve inhalation as an exposure route.

Two forms of chemicals that may be inhaled are particulates and volatile chemicals. Volatilization of contaminants can occur from covered landfills (with and without internal gas generation), spills, leaks onto soil or sludge media, and releases from ER and WM treatment methods. Examples of the types of volatile releases associated with some relevant technologies are shown in table 5.1-1. Fugitive releases of volatile chemicals and particulates can also occur due to process emissions from stacks and vents, equipment openings, and equipment leakage.

The air concentration estimation methods described in this chapter should be performed for each contaminant present at a site or facility. In assessments where modeling is used, a large number of contaminants can often be evaluated at one time. Treatment of multiple contaminants when estimating risks is described in more detail in chapter 8.

Industrial hygiene personnel should be consulted to obtain historical exposure data for workers in TSD facilities when such information is available. At many sites and facilities, measured contaminant air concentrations may not be available and concentrations will need to be estimated using best available data or generic default values such as estimated emission rates generated by the EPA. Many methods exist for estimating air concentrations when actual, known measurements are not available. Such methods include mass balance, engineering calculations, and emission factors and rates. Mass balance provides a means of accounting for all the inputs and outputs of a chemical in a process. A mass balance is useful for estimating releases when other inlet and output streams are quantified (IT 1991). Engineering calculations are generally used to "fill in" information needed for other emission estimation methods. Engineering 
calculations estimate or infer emissions by measurement of secondary parameters such as design information on the unit operation or emission information from similar processes (IT 1991).

Table 5.1-1. Volatile Releases and Associated Technologies

\begin{tabular}{|c|c|}
\hline $\begin{array}{c}\text { Type of Volatilization } \\
\text { Release Model }\end{array}$ & Relerant Technologies \\
\hline $\begin{array}{l}\text { Volatile release from pure phase } \\
\text { organic/volatile material }\end{array}$ & $\begin{array}{l}\text { Excavation } \\
\text { Drum removal } \\
\text { Incineration } \\
\text { Over packing } \\
\text { Encapsulation }\end{array}$ \\
\hline Volatile releases from soil/sludge & $\begin{array}{l}\text { Excavation } \\
\text { Physical separation/sorting } \\
\text { Incineration } \\
\text { In situ bioremediation } \\
\text { Ex situ soil washing } \\
\text { Ex situ bioremediation }\end{array}$ \\
\hline $\begin{array}{l}\text { Volatile release from } \\
\text { contaminated water }\end{array}$ & $\begin{array}{l}\text { Soil flushing } \\
\text { Soil washing } \\
\text { Solvent extraction } \\
\text { Ion exchange } \\
\text { Liquid phase separation } \\
\text { Liquid-liquid extraction } \\
\text { Surface washing } \\
\text { Air stripping } \\
\text { Coagulation/flocculation }\end{array}$ \\
\hline
\end{tabular}

Source: Hardy 1993

For the PEIS, emission rates and applicable models were used to estimate air concentrations. If measured air concentrations are unavailable but the waste inventory or the concentration of contaminant in the parent media (e.g., soil or water) or process feed rates are available, emission rates can be used in conjunction with applicable models to estimate contaminant concentrations in air at the receptor location. Discussed below are various approaches for estimating emission rates. 


\subsubsection{EMISSION RATES FOR ROUTINE OPERATIONS}

An emission rate is the amount of contaminant that becomes airborne per unit time, and it is technologyor process-specific. The amount of contaminant disturbed during excavation of contaminated soil differs from the amount made airborne during air stripping or incineration. During technology implementation, contaminants can be emitted as volatile chemicals or particulates. Technology selection is based, in part, on the contaminants present at a remediation site or WM facility. Certain technologies are designed to remediate or treat volatiles, while others are more effective at remediation or treatment of metals.

For ER, emission rates are used to calculate source strengths (contaminant flux or fluence rates), which are used by models to determine contaminant air concentrations. For VOCs, emission rates are based on contaminated media concentrations and can be either measured or estimated. Particulate emission rates for area sources are related to the amount of soil disturbed by the equipment used. The following sections briefly summarize how emission rates may be generated for both particulates and VOCs. Depending on site-specific concerns, other types of vapor phase chemicals may need to be evaluated.

EPA default emission rates may be used if actual site- or technology-specific emission rates are unknown. Examples of some of these default values are given in subsequent sections; however, the emission rates shown are by no means comprehensive. Default emission rates for technologies not listed here are available in EPA documents. EPA documents contain emission rates for incineration (gases, acid gases, metals, particulate matter), air stripping, stabilization and solidification technologies, organics extraction systems, ultrox international radiation/oxidation technologies, biotreatment and land treatment (EPA 1991a), soil washing (EPA 1991b), gaseous emissions from subsurface soils, nonaerated surface impoundments, volatile nonmethane organic compound emissions from codisposal landfills, free-phase VOC direct emissions to the atmosphere, solids and semivolatile particulate emissions (EPA 1992a), and many others. These emission rates need to be used with caution. These generic emission rates are developed for selected chemicals and particulates.

If measured site- and technology-specific emission rates are available, they are preferable to generic emission rates. Use of generic or default emission rates always produces more uncertainty in final risk results than the use of site- and technology-specific values. When emission rates are unavailable, emission factors or mass loading factors may be used to estimate air concentrations. Particulate emission factors (PEF) (EPA 1991c) relate contaminant concentration in soil to the concentration of respirable particles $\left(\mathrm{PM}_{10}\right)$ in the air due to fugitive dust emissions from surface contamination. Volatilization factors (VFs) 
(EPA 1991c) can be used to define the relationship between the concentration of contaminants in soil and volatilized contaminants in air. Derivation of emission factors and VFs associated with soil handling and Superfund technologies is described elsewhere (EPA 1991a,c; 1989b).

EPA default emission rates are based upon specific VOC contaminant concentrations (ppm). The emission rates should be adjusted to account for the difference between the default concentration and the site-specific contaminant concentration. These conversions or adjustments should be made before estimating the sitespecific source strength. Equations useful for calculating VOC emission rates for water and soils under various site conditions (e.g., steady-state, landfills without internal gas generation) can be found in EPA documents (EPA 1988a).

\subsubsection{ER Mobilization Phase Activities}

Activities in the mobilization phase are usually site preparation activities such as clearing vegetation, grading, or excavating the site. Both VOCs and particulates may be emitted as a result of disturbing contaminated soil with equipment during implementation of these activities. EPA default VOC and particulate emission rates from soil handling activities are shown in table 5.1-2. Controlled emissions are emissions that occur despite pollution control devices, whereas uncontrolled emissions exist when control devices are not implemented. 
Table 5.1-2. Particulate (15 $\mu \mathrm{m})$ and VOC Emission Rates from Soils Handling

\begin{tabular}{|l|c|c|c|}
\hline \multirow{2}{*}{ Technology } & Particulate Emission & \multicolumn{2}{c|}{ Voc Emission Rate (kg/hr) } \\
\cline { 3 - 4 } & Rate (kg/hr) & Controlled & Uncontrolled \\
\hline Excavation & 2 & 0.015 & 0.07 \\
\hline Soil Transport & 15 & 0 & 0.63 \\
\hline Dumping & 0.16 & 0.152 & 5.1 \\
\hline Grading & 4.1 & 0.152 & 5.1 \\
\hline
\end{tabular}

Source: EPA 1989b.

${ }^{a}$ Grading is not expected to increase VOC emissions if performed soon after dumping, so grading ER = dumping ER.

\subsubsection{ER Operation And Maintenance Phase Activities}

Activities in the O\&M phase consist of various waste treatment technologies from installation of cap layers to pumping contaminants from groundwater. Contaminants in environmental media (soil, groundwater, and surface water) that are disturbed by equipment or the implementation of technologies can produce VOC and particulate emissions. In addition, waste treatment units themselves (e.g., incinerators, air strippers, soil vapor extraction units) can emit VOCs and particulates by fugitive emissions or direct off-gassing. Contaminant emissions from disturbing environmental media or from operation of treatment technologies are released into the air where they become available for inhalation or ingestion.

Many methods may be used to derive both fugitive and stack emission rates (EPA 1985b,c,d; EPA 1988a,b; EPA 1989c,d; EPA 1991a,b,d; EPA 1992a) from various ER waste treatment technologies. EPA default VOC emission rates from various technologies are listed in table 5.1-3.

Particulate emissions are dependent on waste and fuel compositions, incinerator type and operation, and the effectiveness of any pollution control devices. EPA default particulate emission rates from two common types of incinerators are listed in table 5.1-4. Uncontrolled particulate emissions can be estimated by procedures outlined in the literature (EPA 1992a). 
Table 5.1-3. VOC Emission Rates for Various Treatment Technologies

\begin{tabular}{|c|c|c|c|}
\hline \multirow[t]{2}{*}{ Technology } & \multirow[t]{2}{*}{ Pollutant } & \multicolumn{2}{|c|}{ Estimated Emission Rates (g/hr) } \\
\hline & & Controlled & Uncontrolled \\
\hline \multicolumn{4}{|l|}{ THERMAL TREATMENTS: } \\
\hline \multirow[t]{7}{*}{ Rotary kiln incineration" } & Voc & 340 & 340 \\
\hline & Metals & 170 & 170 \\
\hline & $\mathrm{HCI}$ & 1.4 & 140 \\
\hline & HF & 0.4 & 40 \\
\hline & $\mathrm{SO}_{2}$ & 17 & 340 \\
\hline & $\mathrm{CO}$ & 3,510 & 3510 \\
\hline & No, & 11,530 & 11,530 \\
\hline \multirow[t]{7}{*}{ Infrared Incineration } & VOC & 10 & 10 \\
\hline & Metals & 5 & 5 \\
\hline & $\mathrm{HCI}$ & 0.041 & 4.1 \\
\hline & HF & 0.011 & 1.1 \\
\hline & $\mathrm{SO}_{2}$ & 0.5 & 10 \\
\hline & $\mathrm{CO}$ & 2.7 & 2.7 \\
\hline & NO, & 16 & 16 \\
\hline Air stripping & voc & 342 & 3420 \\
\hline Soil vapor extraction & VOC & 1250 & 25,000 \\
\hline $\begin{array}{l}\text { Solidification and } \\
\text { stabilization }\end{array}$ & VOC & N/A & 5460 \\
\hline \multicolumn{4}{|l|}{$\begin{array}{l}\text { Physical and Chemircal } \\
\text { Treatament Methods: }\end{array}$} \\
\hline Uitrox oxidation & VOC & N/A & 4.5 \\
\hline \multicolumn{4}{|l|}{$\begin{array}{l}\text { BIOTREATMENT AND LAND } \\
\text { TREATMEENT: }\end{array}$} \\
\hline $\begin{array}{l}\text { Flow-through treatment } \\
\text { with mechanical aeration }\end{array}$ & voc & N/A & 4800 \\
\hline $\begin{array}{l}\text { Quiescent flow-through } \\
\text { treament }\end{array}$ & voc & N/A & 720 \\
\hline Disposal impoundments & voc & N/A & 48.6 \\
\hline
\end{tabular}

Source: EPA 1991a.

Based on a typical incinerator with heat load of $63 \mathrm{MM}$ kilojoules $/ \mathrm{hr}$, waste feed of $3400 \mathrm{~g} / \mathrm{hr}$, and stack gas flow of 986 $\mathrm{m}^{3} / \mathrm{min}$.

${ }^{b}$ Air stripping values are for a small-size unit; for medium and large units, the values increase by a factor of 10 for each size increase. 
Table 5.1-4. Particulate Emission Rates for Incineration

\begin{tabular}{|l|c|c|}
\hline \multirow{2}{*}{ Technology } & \multicolumn{2}{|c|}{ Estimated Emission Rates (g/hr) } \\
\cline { 2 - 3 } & Controlled & Uncontrolled \\
\hline Rotary kiln incineration & 4,260 & 695,000 \\
\hline Infrared incineration & 16.2 & $0.6-2.9$ \\
\hline
\end{tabular}

Source: EPA 1991a.

\subsubsection{ER Closure Phase Activities}

For this methodology, it is assumed that closure and post-closure activities generally consist of final D\&D of equipment and materials used in the implementation of a treatment technology: D\&D activities include surface removal of contamination, abrasive blasting, and high-pressure power washing. Both VOC and particulate contaminant emissions may be produced as a result of these activities. EPA default emission rates for similar technologies may be modified to reflect emission rates of contaminants during D\&D activities.

\subsubsection{WM Activities}

Contaminant emissions from WM treatment, storage, and disposal activities may be vapor phase chemicals or particulates. Waste treatment activities typically occur indoors, while handling may occur either indoors or outdoors. Fugitive emissions, those emissions that occur due to equipment leakages, may affect workers since contaminants emitted from indoor fugitive emissions may be available for inhalation.

Protocols for generating unit-specific emission estimates for equipment leaks are shown in table 5.1-5 (EPA 1988c). Fugitive emissions may have to be estimated by using emission factors or engineering analysis since they are often too diffuse or dilute to be measured directly (IT 1991). The generally accepted method of estimating releases from leaks in vessels, pipes, and valves is to use emission factors. For the PEIS, it is assumed that $5-10 \%$ of these emissions are due to equipment leakage and these values are used as emission rates to calculate indoor (and outdoor ground-level releases) air concentrations that may affect workers. 
Contaminants may also become airborne through resuspension of particulate surface contamination during handling of waste containers. Depending on the type of waste and the type of WM facility, airlocks and remote operations may be used to prevent inhalation of contaminants.

Table 5.1-5. Average Fugitive Emission Factors ${ }^{\text {,b }}$

\begin{tabular}{|l|c|}
\hline \multicolumn{1}{|c|}{ Fugitive Emission Source } & Emission Factor $(\mathrm{g} / \mathrm{s})$ \\
\hline $\begin{array}{l}\text { Pump seals } \\
\text { light liquids } \\
\text { heavy liquids }\end{array}$ & $\begin{array}{c}0.014 \\
0.0059\end{array}$ \\
\hline Valves (in-line) & \\
gas & 0.0015 \\
light liquid & 0.002 \\
heavy liquid & 0.000064 \\
\hline Gas safety-relief valves & 0.029 \\
\hline Open-ended lines & 0.00047 \\
\hline Flanges & 0.00023 \\
\hline Sampling connections & 0.0028 \\
\hline Compressor seals & 0.063 \\
\hline
\end{tabular}

Source: EPA 1988c.

These factors take into account a leak frequency determined from field studies in the synthetic organic chemicals manufacturing industry. Light liquids have a vapor pressure greater than $0.1 \mathrm{psia}$ at $100^{\circ} \mathrm{F}$.

${ }^{b}$ Factors have been converted from $\mathrm{lb} / \mathrm{hr}$ in the original source.

\subsubsection{Estimation Of Source Strengths}

Once emission rates for an activity or technology are known, a source strength (flux or fluence rate) is estimated and air concentrations are then estimated based on source-receptor configurations. The source strength is the mass of contaminant emitted from the source per unit area per unit time, and it is used as input into area source models to estimate contaminant air concentrations. For VOCs, the source strength can be estimated from the emission rate as follows: 


$$
S S=\frac{C * E R}{C_{E R} * A}
$$

$$
\begin{aligned}
& \text { where SS = source strength }\left(\mathrm{g} / \mathrm{m}^{2}-\mathrm{s}\right) \text {, } \\
& \text { C = concentration of contaminant }(\mathrm{mg} / \mathrm{kg}) \text {, } \\
& \mathrm{C}_{\mathrm{ER}}=\text { concentration of contaminant upon which ER is based }(\mathrm{mg} / \mathrm{kg}) \text {, } \\
& \text { ER = emission rate }(\mathrm{g} / \mathrm{s}) \text {, } \\
& \text { A = source area that emission rate is based on }\left(\mathrm{m}^{2}\right) \text {. }
\end{aligned}
$$

Emission rates for particulates during remediation of area sources are not based on contaminant concentration or area size directly, but rather on the amount of agitation of soil produced by the use of remedial equipment (e.g., bulldozers). The emission rates for particulates are given in units of grams of inhalable particles per second. These emission rates must be multiplied by the contaminant concentration in the soil to produce emission rates in units of inhalable contaminant particles emitted per second. For particulates, the source strength can be estimated as follows:

$$
S S=\frac{C * E R}{A * 10^{6}}
$$

where SS = source strength $\left(\mathrm{g} / \mathrm{m}^{2}-\mathrm{s}\right.$ or $\left.\mathrm{pCi} / \mathrm{m}^{2}-\mathrm{s}\right)$,

$\mathrm{C}=$ concentration of contaminant $(\mathrm{mg} / \mathrm{kg}$ or $\mathrm{pCi} / \mathrm{g})$,

$\mathrm{ER}=$ emission rate $(\mathrm{g} / \mathrm{s})$,

A = source area $\left(\mathrm{m}^{2}\right)$,

$10^{6}=$ unit conversion $(\mathrm{mg} / \mathrm{kg})$.

\subsubsection{AIr Concentration Estimation Methods}

Estimation of ER technology-specific air concentrations at worker locations requires data such as source type, contaminant concentrations, source strength, ER processes, emission sources (e.g., stack, fugitive dust, leakage), and worker activities. 
The source type greatly affects how air concentrations are estimated. Two types of sources are generally considered, point and area sources. A point source is a source of contamination that can be pinpointed to one specific localized source, such as the stack of an incinerator. An area source is a source of contamination that is broad and widespread, such as a plot of contaminated soil. Landfills and surface impoundments are considered area sources, whereas incinerators and in situ soil vapor extraction units are considered point sources. In many cases, technologies could be considered both area and point sources. For example, a liquid waste treatment may include an aeration pond (area source) downstream from an ion exchange column system (point source). To further complicate the issue, processes may be indoor, outdoor or a combination of both. For this reason, process system (and process unit) information and worker patterns and configurations are required to estimate contaminant air concentrations.

A number of EPA documents provide information relevant to ER technology processes and methods for estimating process emission rates and air concentrations. However, the bulk of this work is for the estimation of offsite air impacts. For estimation of onsite remedial and TSD worker exposures, emission rate data may still be relevant, but the models used to estimate air concentrations are different. For workers involved in outdoor activities, area source models such as the PAL model (EPA 1987a) are used for workers located on or near the source. For point sources, the TSCREEN model (EPA 1990) is used to estimate near field air concentrations. Area and point sources can be further divided into continuous and instantaneous releases (EPA 1988d). The source and release types are summarized in table 5.1-6. For workers involved in indoor activities, such as WM and D\&D workers, fugitive emission rates attributed to equipment leakage and indoor room models are useful for estimating air concentrations. 
Table 5.1-6. Release Types and Associated Model Categories

\begin{tabular}{|c|c|c|}
\hline $\begin{array}{l}\text { Initial Form } \\
\text { of Release }\end{array}$ & Release Type & $\begin{array}{l}\text { Modeling } \\
\text { Category" }\end{array}$ \\
\hline \multirow[t]{3}{*}{ Particulate Matter } & \multirow{3}{*}{$\begin{array}{l}\text { Stack } \\
\text { Fugitive Dust } \\
\text { Duct Failure }\end{array}$} & CP \\
\hline & & $\mathrm{CA}$ \\
\hline & & IV \\
\hline \multirow[t]{7}{*}{ Gases } & Flares & $\mathrm{CP}$ \\
\hline & Stacks, relief valves, vents & $\mathbf{C P}$ \\
\hline & Gas leaks: tanks, pipes, pumps, compressors & CP \\
\hline & Multiple fugitive emissions & $\mathrm{CA}$ \\
\hline & Land treatment emissions & $\mathrm{CA}$ \\
\hline & Landfill emissions & CA \\
\hline & Equipment openings & IV \\
\hline \multirow[t]{8}{*}{ Liquids } & Surface impoundments (quiescent) & CA \\
\hline & Surface impoundments (aerated) & $\mathrm{CA}$ \\
\hline & Continuous relief valve discharge & $\mathbf{C P}$ \\
\hline & Instantaneous relief valve discharge & IP \\
\hline & Liquid leaks: pipes & $\mathrm{CA}$ \\
\hline & Liquid leaks: tanks & $\mathrm{CA}$ \\
\hline & Liquid leaks: pipes (high volatility) & $\mathrm{CP}$ \\
\hline & Liquid leaks: tanks (high volatility) & $\mathrm{CP}$ \\
\hline
\end{tabular}

Source: EPA 1988d.

${ }^{2}$ C-continuous, P-point, A-area, I-instantaneous, V-volume.

\subsubsection{Area Source Models}

For estimating air concentrations from outdoor area sources, the model used in this methodology is the PAL model (EPA 1987a), although a box model (Hanna et al. 1982) can be used as a less complex alternative. The PAL model estimates short-term dispersion using Gaussian plume steady-state and flat 
terrain assumptions. The PAL code can be used for estimating concentrations of nonreactive pollutants at 99 receptors for an averaging time of 1 to $24 \mathrm{hrs}$ (EPA 1987a).

The PAL model divides an area source into a number of finite line sources that are perpendicular to the wind direction. An integration is performed, using the concentration contributions from the line sources, that generates an estimate of the contaminant air concentration produced by the area source. Receptors may be located at any position relative to the pollution source. Remedial workers are often located near the area source and many times they are "on source" receptors. The PAL model allows the user to place a receptor at these near-field positions. The model also has the capability to estimate the contaminant air concentration produced by the contaminated area at any receptor point. Data required for the PAL model consist of the following:

- Coordinates of the receptor $(\mathrm{km})$,

- Height of the receptor above ground level (m),

- Source strength $\left(\mathrm{g} / \mathrm{s}-\mathrm{m}^{2}\right)$,

- Source height (m),

- East coordinate of south-west corner $(\mathrm{km})$,

- North coordinate of south-west corner $(\mathrm{km})$,

- Meteorological data such as wind speed and direction, stability class, mixing height, ambient air temperature, and diurnal variation (representative of the source-receptor locality).

The PAL algorithms have been evaluated for the use of area sources at Superfund sites (EPA 1989b). Tests of mathematical and physical principles indicated that the PAL model is physically reasonable for all tests: stability comparisons, center versus edge, subdivisions, source orientation, and source height (EPA 1989b). PAL model predictions are sensitive to source height.

As an alternative to the PAL model, the box model can be used to assess area sources. Use of the box model assumes that a contaminant is uniformly mixed within a given layer or volume. A steady wind is assumed to sweep through that layer or volume. The receptor is assumed to be located somewhere within the volume. The box model is used to calculate an average air concentration for the entire volume. 


\subsubsection{Point Source Models}

For estimating air concentrations from point sources, the models used in this methodology are the TSCREEN model for outdoor sources and a room model for indoor sources. These models are described in the following subsections.

\subsection{Outdoor Activities}

The point source model used in this methodology is TSCREEN (EPA 1990). TSCREEN is used to estimate air concentrations from point sources associated with outdoor activities. TSCREEN is an umbrella model with three different models imbedded in it: SCREEN, RVD (Relief Valve Discharge), and Puff. The RVD model is a screening technique applicable to denser-than-air gaseous releases. The Puff model can be used for short-duration events that can be simulated as instantaneous passively dispersing puffs, such as duct failure scenarios. For continuous point sources, such as would be expected during ER activities, the SCREEN model portion is primarily used. SCREEN can perform single source, short-term estimations of maximum ground-level concentrations. It incorporates the effect of building downwash in maximum concentrations in the cavity recirculation zone for near wake and wake regions. SCREEN can estimate air concentrations from gaseous, liquid, or particulate matter releases from stacks, vents, and fugitive or windblown dust emissions. The types of data needed to estimate air concentrations using SCREEN include the following:

- Emission rate $(\mathrm{g} / \mathrm{s})$,

- Stack height (m),

- Stack inside diameter (m),

- Stack gas exit velocity $(\mathrm{m} / \mathrm{s})$,

- Stack gas temperature (K),

- Ambient temperature (K),

- Receptor height above ground (m),

- Urban/rural setting,

- Meteorology (stability classes and wind speeds),

- Source-to-receptor distances. 
SCREEN is limited in that it is a screening level model and its input does not allow wind rose data. Although TSCREEN can be used as an area source model using a virtual point source procedure, PAL is a more accepted model for estimating concentrations associated with area sources.

\subsection{Indoor Activities}

For indoor activities, air concentrations from point sources can be estimated using room models (NCRP 1989; Jayjock 1988). In this methodology, the method used to estimate indoor contaminant air concentrations from sources located within a room is a general ventilation room model (Jayjock 1988). This model does not account for the deposition of particulates onto structural or equipment surfaces. Instead, particulates are assumed to be totally available for ingestion and inhalation. This assumption results in a more conservative risk estimate. The following equation can be used to estimate contaminant air concentrations (Jayjock 1988):

$$
A C=\left(\frac{E R}{Q^{\prime}}\right)+\left[A C_{0}-\left(\frac{E R}{Q^{\prime}}\right)\right] * e^{\frac{-Q^{\prime} t}{V}}
$$

where $A C=$ air concentration $\left(\mathrm{g} / \mathrm{m}^{3}\right.$ or $\left.\mathrm{pCi} / \mathrm{m}^{3}\right)$,

$\mathrm{ER}=$ emission rate, $(\mathrm{g} / \mathrm{s}$ or $\mathrm{pCi} / \mathrm{s})$,

$\mathrm{AC}_{0}=$ air concentration at time $\mathrm{t}=0\left(\mathrm{~g} / \mathrm{m}^{3}\right.$ or $\left.\mathrm{pCi} / \mathrm{m}^{3}\right)$,

$Q^{\prime} \quad=$ effective volumetric ventilation rate in and out of room $\left(\mathrm{m}^{3} / \mathrm{s}\right) ; \mathrm{Q}^{*} \mathrm{p}$,

$\mathrm{V}=$ room volume $\left(\mathrm{m}^{3}\right)$,

$\mathrm{Q}=$ volumetric ventilation rate in and out of room $\left(\mathrm{m}^{3} / \mathrm{s}\right)$,

t $=$ time (s),

$\mathrm{p} \quad=$ mixing factor (unitless).

At steady-state equilibrium (i.e., large values for $t$ ), the air concentration equation simplifies to the following:

$$
A C=\frac{E R}{Q^{\prime}},
$$


where

$$
\begin{aligned}
& \mathrm{AC}=\text { air concentration }\left(\mathrm{g} / \mathrm{m}^{3} \text { or } \mathrm{pCi} / \mathrm{m}^{3}\right) \\
& \mathrm{ER}=\text { emission rate }(\mathrm{g} / \mathrm{s} \text { or } \mathrm{pCi} / \mathrm{s}) \\
& \mathrm{Q}^{\prime} \quad=\text { volumetric ventilation rate }\left(\mathrm{m}^{3} / \mathrm{s}\right)
\end{aligned}
$$

More complicated types of models are available as well as more simplistic equations. The type of method used depends on site-specific needs.

\subsubsection{Exposure Criteria}

Estimated air concentrations should be compared to occupational exposure criteria, such as TLVs for chemicals and derived air concentrations (DACs) for radionuclides to evaluate worker exposure conditions. If TLVs do not exist for a specific contaminant, RELs or Permissible Exposure Limits (PELs) are used. Estimated air concentration of a chemical may also be compared to $10 \%$ of the "immediately dangerous to life and health" (IDLH) concentration, which is considered to be the boundary between reversible and negligible health effects. This methodology assumes the use of good work practices under normal conditions. Many ER-related activities and possibly some WM maintenance operations may require the use of PPE. In these cases, the estimated air concentrations are reduced by the use of a NIOSH APF, which is associated with certain types of respiratory protection equipment. The levels of protection and the corresponding APFs used in this analysis are listed in table 5.1-7. These APFs were selected for the PEIS analysis. For site-specific assessments, APFs are chosen that are associated with actual respirator configurations (NIOSH 1990). When comparing contaminants to the APF, the following equation can be used to estimate the air concentration that is within exposure limits:

$$
C_{\text {adj }}=\frac{C_{o}}{A P F},
$$

$$
\text { where } \quad \begin{aligned}
& C_{2 d j}=\text { adjusted air concentration }\left(\mathrm{g} / \mathrm{m}^{3}\right), \\
& C_{0}=\text { original air concentration }\left(\mathrm{g} / \mathrm{m}^{3}\right), \\
& \text { APF }=\text { air protection factor. }
\end{aligned}
$$


Table 5.1-7. Assigned Protection Factors

\begin{tabular}{|c|c|c|}
\hline Level of Protection & Respiratory Equipment & Assigned Protection Factor \\
\hline A & $\begin{array}{l}\text { SCBA }^{\mathrm{a}} \text { : pressure demand, full- } \\
\text { face; pressure demand with } \\
\text { escape }\end{array}$ & 10,000 \\
\hline B & $\begin{array}{l}\text { SCBA: pressure demand, full- } \\
\text { face } \\
\text { Supplied air: pressure demand } \\
\text { with escape SCBA }\end{array}$ & 1,000 \\
\hline C & $\begin{array}{l}\text { Full face piece air purifying } \\
\text { canister, equipped respirator } \\
\text { (particulate or VOC) }\end{array}$ & 50 \\
\hline $\mathrm{D}$ & No respiratory protection & 1 \\
\hline
\end{tabular}

Source: NIOSH 1990.

${ }^{a}$ Self Contained Breathing Apparatus

\subsubsection{INHALATION INTAKE VALUES}

Air concentrations (either known or estimated) can be used to estimate intake. Intake values are used in the risk characterization stage of the risk evaluation to determine noncarcinogenic hazards and cancer incidence. Intake of chemically contaminated air via inhalation is calculated as follows:

$$
I=\frac{I_{h} R * C_{Q} * E D * E T * E F}{B W * A T}
$$

where $I$ = Contaminant-specific average individual intake from breathing contaminated air (mg/kg-d),

$\mathrm{I}_{\mathrm{h}} \mathrm{R}=$ Inhalation rate for individuals $\left(\mathrm{m}^{3} / \mathrm{hr}\right)$,

$\mathrm{C}_{\mathrm{a}}=$ Contaminant-specific air concentration $\left(\mathrm{mg} / \mathrm{m}^{3}\right)$,

ED = Exposure duration (yr),

ET = Exposure time $(\mathrm{hr} / \mathrm{d})$,

$\mathrm{EF} \quad=$ Exposure frequency $(\mathrm{d} / \mathrm{yr})$, 


$$
\begin{aligned}
& \mathrm{BW}=\text { Body mass }(\mathrm{kg}), \\
& \mathrm{AT}=\text { Averaging time (noncarcinogens } \mathrm{AT}=\mathrm{ED} \text {; carcinogens } \mathrm{AT}=25,550 \mathrm{~d} \text { ). }
\end{aligned}
$$

Exposure durations may vary among types of workers. For remedial workers, exposure durations are usually subchronic (between 2 wks to $7 \mathrm{yrs}$ ), depending on the type of technology being used and the extent of contamination. For WM workers, exposure duration may result in chronic exposures since TSD workers may maintain the same job type for $>7$ yrs. Adverse health effects can also occur due to acute exposures, which may occur during nonroutine events. In the case of nonroutine events, the exposure duration used to estimate risks is usually very short, and the toxicity values used should reflect acute rather than subchronic exposure durations.

Exposure monitoring and other exposure assessment data should be used to determine the exposure duration whenever possible. Use of actual data will allow the risk assessment to proceed based on task exposure and full shift exposure and will improve the accuracy of the exposure estimates. In the absence of actual data, the average time required to complete a task should be used, which often must be derived from personnel who typically plan operations (e.g., engineers, supervisors, etc.). Use of estimated or average exposure durations will necessarily increase the uncertainty of the exposure estimates and subsequent risk; however, on a programmatic or installation-wide level, often these types of data are all that are available for use. Moreover, the uncertainty will be reflected across all the estimates and the use of the risk results for relative risk comparisons should not be adversely affected.

For ER workers, hours spent performing remedial activities can be estimated in the absence of known sitespecific data. The exposure duration can be equated with the duration of the activity, which is derived by applying duration factors to the volume of material to be remediated. These duration factors are processdependent and are calculated based on the average duration of a given remedial activity. For example, a backhoe has a certain capacity and requires a given amount of time to excavate soil, maneuver, and deposit the soil elsewhere. This capacity is called the cycling time, and it is the basis for the derivation of duration factors. Process-specific duration factors can be obtained from equipment manufacturers, remediation engineers and from EPA guidance documents.

For WM workers, hours spent operating TSD facilities may be estimated using full-time equivalent workers, or FTEs, and assuming they are working for approximately $2000 \mathrm{hrs} / \mathrm{yr}$. This estimate should be modified by assuming a percentage of availability of the TSD facility, decreasing the number of hours 
worked by approximately 30\% (ORNL 1995a). Specific methods used for estimating exposure durations for WM workers for programmatic analyses are presented in greater detail elsewhere (ORNL 1995a).

The inhalation rate for workers varies based on the type of activity in which they are involved. For light activity, the breathing rate for an adult male is $0.8 \mathrm{~m}^{3} / \mathrm{hr}$; for moderate activity the breathing rate is 2.5 $\mathrm{m}^{3} / \mathrm{hr}$; for strenuous activity the breathing rate is $4.8 \mathrm{~m}^{3} / \mathrm{hr}$ (EPA 1989c). Heavy equipment operators are usually categorized as having a light breathing rate, while manual laborers are assumed to have a moderate breathing rate. Strenuous activities that require the highest breathing rate are assumed to be rare. Physiological monitoring records and professional judgement are used to determine the breathing rate for an activity.

\subsection{Ingestion Route}

Ingestion is a potential exposure route of concern for remediation workers during such soil handling activities as excavation, burial, stabilization, and solidification of waste. It could also become a factor when decommissioning and decontamination activities take place. Tables 4.2-1 and 4.2-2 provide summaries of the activities that involve the ingestion route. Ingestion of particulates occurs when workers are exposed to contaminants by suspension of dust from mechanical agitation, wind-generated dust, or by ingesting soil that is on their skin. It is assumed that WM workers are typically protected from ingestion of particulates by engineering controls and safe working practices.

EPA estimates the ingestion rate of particulates for adults working outdoors to be $480 \mathrm{mg} / \mathrm{d}$ (EPA 1989c). Other sources recommend using $50 \mathrm{mg} / \mathrm{d}$ as the "typical" value for adult ingestion of soil (EPA 1991c). For activities that involve a significant amount of mechanical activity (e.g., excavation, capping, burial activities), an ingestion rate of $480 \mathrm{mg} / \mathrm{d}$ is used. This ingestion rate is based on a soil ingestion rate for an individual performing yardwork, which is analogous to someone engaged in construction or landscaping. Daily intake of chemicals via soil ingestion can be estimated by the following equation.

$$
\text { Intake }=\frac{\left(I R_{g} * C * F I * E F * E D * E T\right)}{(B W * A T)}
$$


where $C=$ concentration of the chemical in soil $(\mathrm{mg} / \mathrm{g})$,

$\mathrm{IR}_{\mathrm{g}}=$ ingestion rate ( $\mathrm{g}$ of soil/ $\mathrm{hr}$ ),

$\mathrm{EF} \quad=$ exposure frequency (days/yr),

FI = fraction ingested,

ED = exposure duration (yrs),

ET = exposure time (hrs/day),

$\mathrm{BW}=$ body mass $(\mathrm{kg})$,

$\mathrm{AT}=$ averaging time (d, noncarcinogens $\mathrm{AT}=\mathrm{ED}$; carcinogens $\mathrm{AT}=25,550 \mathrm{~d}$ ).

For workers wearing PPE, intake via the ingestion route is reduced. It is assumed for the PEIS that for PPE levels $A$ and $B$, no ingestion occurs. For level $C$, the air concentration inside the respirator is calculated as follows:

$$
C_{M}=C_{0} * R F * P E
$$

$$
\text { where } \begin{aligned}
& \mathrm{C}_{\mathrm{o}}=\text { initial ambient air concentration }\left(\mathrm{g} / \mathrm{m}^{3}\right), \\
& \mathrm{RF}=\text { respirable fraction of ambient aerosol, } \\
& \mathrm{PE}=\text { penetration efficiency for respirator, } \\
& \mathrm{C}_{\mathrm{M}}=\text { inside mask air concentration }\left(\mathrm{g} / \mathrm{m}^{3}\right)
\end{aligned}
$$

For the PEIS, it is assumed that $5 \%$ of the ambient aerosol is respirable and the penetration efficiency is $45 \%$. For level D, no respirators are assumed; therefore, there is no adjustment of the ambient air concentration. The ingestion exposure route can also include the skin $\rightarrow$ ingestion exposure route. It is difficult to quantify the percentage of contaminant in soil that would be ingested via this route. It is assumed for the PEIS that proper decontamination procedures are used at ER sites, rendering this route negligible.

\subsection{Example ER Exposure Quantification: Chemical}

An example calculation for estimating intakes during hypothetical site remediation activities for a site contaminated with a carcinogenic chemical is shown below. The calculated intakes are from inhalation and 
ingestion exposure routes. The site being remediated is modeled as a cube, with a side length of $10 \mathrm{~m}$ (11 yd). The soil is contaminated with $500 \mathrm{mg} / \mathrm{kg}$ of benzene, a carcinogenic VOC. The remediation technology selected is excavation of the contaminated area. This activity can be further divided into the following subactivities: excavation of uncontaminated soil, excavation of contaminated soil (overburden), backfill and compaction, and packaging of soil. The intakes attributed to each of these activities are evaluated for three worker types: two laborers, one heavy equipment operator, and one supervisor. The number of person-hours spent performing these activities and the exposure routes evaluated for each are shown in table 5.3-1 and are for example purposes only.

Table 5.3-1. Person-hours and Exposure Routes for Excavation

\begin{tabular}{|c|c|c|c|c|c|c|c|c|}
\hline \multirow[t]{2}{*}{ Subactivity } & \multicolumn{3}{|c|}{ Number of person-hours } & \multirow{2}{*}{$\begin{array}{c}\text { Exposure } \\
\text { Route } \\
\text { Evaluated }\end{array}$} & \multicolumn{3}{|c|}{ Inhalation Rate $\left(\mathrm{m}^{3} / \mathrm{hr}\right)$} & \multirow{2}{*}{$\begin{array}{c}\text { VOC } \\
\text { Emission } \\
\text { Rate } \\
(\mathrm{g} / \mathrm{s}) \\
\end{array}$} \\
\hline & $\mathbf{L A B}^{\mathbf{a}}$ & $\mathbf{H E O}^{\mathbf{b}}$ & SUP & & $\mathbf{L A B}^{\mathbf{a}}$ & $\mathbf{H E O}^{\mathbf{b}}$ & SUPC & \\
\hline $\begin{array}{l}\text { Excavation of } \\
\text { overburden }\end{array}$ & 17 & 8.5 & 8.5 & $\begin{array}{c}\text { inhalation } \\
\text { and } \\
\text { ingestion }\end{array}$ & 2.5 & 0.8 & 0.8 & $4.2 \mathrm{E}-3$ \\
\hline $\begin{array}{l}\text { Excavation of } \\
\text { contaminated soil }\end{array}$ & 21.5 & 10.8 & 10.8 & $\begin{array}{c}\text { inhalation } \\
\text { and } \\
\text { ingestion }\end{array}$ & 2.5 & 0.8 & 0.8 & $4.2 \mathrm{E}-3$ \\
\hline $\begin{array}{l}\text { Backfill and } \\
\text { compaction }\end{array}$ & 15.5 & 7.8 & 7.8 & $\begin{array}{c}\text { inhalation } \\
\text { and } \\
\text { ingestion }\end{array}$ & 2.5 & 0.8 & 0.8 & $4.2 \mathrm{E}-3$ \\
\hline $\begin{array}{l}\text { Packaging of } \\
\text { contaminated soil }\end{array}$ & 10 & 5 & 5 & $\begin{array}{c}\text { inhalation } \\
\text { and } \\
\text { ingestion }\end{array}$ & 2.5 & 0.8 & 0.8 & $3.5 \mathrm{E}-2$ \\
\hline
\end{tabular}

${ }^{2} \mathrm{LAB}=$ laborer

${ }^{b} \mathrm{HEO}=$ heavy equipment operator

${ }^{\mathrm{C}}$ SUP $=$ supervisor

Inhalation exposure is calculated by first estimating the source strength. The source strength can be estimated using equation 5.8. The emission rates presented in table 5.3-1 are modified from the generic emission rates presented earlier to reflect site-specific conditions. The emission rates in this example are based on a contaminant concentration of $100 \mathrm{mg} / \mathrm{kg}$ and an area of $10 \mathrm{~m}$ (11 yd) by $10 \mathrm{~m}$ 
(11 yd). For the excavation of overburden and backfill and compaction activities, the soil contaminant concentration was reduced by a factor of 10,000 . This is an engineering judgement based on the fact that these activities involve the disturbance of primarily "clean" soil. The source strength is calculated to be $2.1 \mathrm{E}-8 \mathrm{~g} / \mathrm{m}^{2}-\mathrm{s}$ for these two activities. For the excavation of contaminated soil activity, the source strength is calculated to be $2.1 \mathrm{E}-4 \mathrm{~g} / \mathrm{m}^{2}-\mathrm{s}$. The packaging of contaminated soil activity has a source strength of $1.8 \mathrm{E}-3 \mathrm{~g} / \mathrm{m}^{2}-\mathrm{s}$. Using the parameters defined in table 5.3-2, the air concentration of benzene is calculated by the PAL model. For the example it was assumed that the worker was standing at one corner of the contaminated area with the wind blowing from the opposing corner down the diagonal. The configuration represents a maximally exposed worker scenario and is known as the “diagonal" configuration.

The air concentrations of benzene calculated by the PAL model are $1.95 \mathrm{E}-8 \mathrm{~g} / \mathrm{m}^{3}$ for excavation of overburden, $1.95 \mathrm{E}-4 \mathrm{~g} / \mathrm{m}^{3}$ for excavation of contaminated soil, $1.95 \mathrm{E}-8 \mathrm{~g} / \mathrm{m}^{3}$ for backfill and compaction, and $1.64 \mathrm{E}-3 \mathrm{~g} / \mathrm{m}^{3}$ for packaging of contaminated soil. The TLV for benzene is $3.0 \mathrm{E}-4 \mathrm{~g} / \mathrm{m}^{3}$. The predicted air concentrations for benzene fall below the TLV for all technologies except packaging of contaminated soil. Level D PPE is therefore sufficient during all technologies except packaging of contaminated soil, which will require level C PPE. Therefore, the contaminant air concentration for soil packaging is divided by an APF of 50 to become $3.28 \mathrm{E}-5 \mathrm{~g} / \mathrm{m}^{3}$. 
Table 5.3-2. PAL Parameters Used in Example Calculation

\begin{tabular}{|c|c|c|}
\hline \multicolumn{2}{|c|}{ PAL Parameter } & Value \\
\hline \multirow{3}{*}{$\begin{array}{l}\text { Source } \\
\text { Strength }\end{array}$} & $\begin{array}{l}\text { Excavation of overburden/ } \\
\text { backfill and compaction }\end{array}$ & $2.1 \mathrm{E}-8 \mathrm{~g} / \mathrm{m}^{2}-\mathrm{s}$ \\
\hline & $\begin{array}{l}\text { Excavation of contaminated } \\
\text { soil }\end{array}$ & $2.1 \mathrm{E}-4 \mathrm{~g} / \mathrm{m}^{2}-\mathrm{s}$ \\
\hline & $\begin{array}{l}\text { Packaging of contaminated } \\
\text { soil }\end{array}$ & $1.8 \mathrm{E}-3 \mathrm{~g} / \mathrm{m}^{2}-\mathrm{s}$ \\
\hline \multicolumn{2}{|c|}{ Dimensions of area source } & $10 \mathrm{~m}$ by $10 \mathrm{~m}$ \\
\hline \multicolumn{2}{|c|}{ Source height } & $0 \mathrm{~m}$ \\
\hline \multicolumn{2}{|c|}{ Wind increase with height } & none \\
\hline \multicolumn{2}{|c|}{ Urban/rural dispersion coefficients } & rural \\
\hline \multicolumn{2}{|c|}{ Gravitational settling } & none \\
\hline \multicolumn{2}{|c|}{ Receptor configuration } & diagonal \\
\hline \multicolumn{2}{|c|}{ Wind direction } & $315^{\circ}$ \\
\hline \multicolumn{2}{|c|}{ Wind speed } & $2 \mathrm{~m} / \mathrm{s}$ \\
\hline \multicolumn{2}{|c|}{ Stability class } & 2 \\
\hline \multicolumn{2}{|c|}{ Mixing height } & $100 \mathrm{~m}$ \\
\hline \multicolumn{2}{|c|}{ Receptor height } & $1.5 \mathrm{~m}$ \\
\hline \multicolumn{2}{|c|}{ Hourly variation in emissions } & none \\
\hline
\end{tabular}

The intake of benzene via inhalation can be calculated by substituting the air concentrations into equation 5.17. This calculation should be performed for each worker type for each activity to account for the different inhalation rates. Workers are assumed to have a body mass of $70 \mathrm{~kg}(154 \mathrm{lb})$. Intake via ingestion can be calculated by using equation 5.18, using an ingestion rate of $0.06 \mathrm{~g} / \mathrm{hr}$ and a fraction ingested of 0.4. The intake of benzene via inhalation and ingestion are shown in table 5.3-3. 
Table 5.3-3. Benzene Intake via Inhalation and Ingestion

\begin{tabular}{||c|c|c|c|c|c|c|}
\hline \multirow{2}{*}{ Subactivity } & \multicolumn{3}{|c|}{ Inhalation (mg/kg-d) } & \multicolumn{3}{c|}{ Ingestion (mg/kg-d) } \\
\cline { 2 - 7 } & LAB $^{\mathrm{a}}$ & HEO $^{\mathrm{b}}$ & SUP $^{\mathrm{c}}$ & LAB $^{\mathrm{a}}$ & HEO $^{\mathrm{b}}$ & SUP $^{\mathrm{y}}$ \\
\hline $\begin{array}{l}\text { Excavation of } \\
\text { overburden }\end{array}$ & $6.5 \mathrm{E}-10$ & $1.0 \mathrm{E}-10$ & $1.0 \mathrm{E}-10$ & $1.6 \mathrm{E}-11$ & $8.0 \mathrm{E}-12$ & $8.0 \mathrm{E}-12$ \\
\hline $\begin{array}{l}\text { Excavation of } \\
\text { contaminated soil }\end{array}$ & $8.2 \mathrm{E}-6$ & $1.3 \mathrm{E}-6$ & $1.3 \mathrm{E}-6$ & $2.0 \mathrm{E}-7$ & $1.0 \mathrm{E}-7$ & $1.0 \mathrm{E}-7$ \\
\hline $\begin{array}{l}\text { Backfill and } \\
\text { compaction }\end{array}$ & $5.9 \mathrm{E}-10$ & $9.5 \mathrm{E}-11$ & $9.5 \mathrm{E}-11$ & $1.5 \mathrm{E}-11$ & $7.3 \mathrm{E}-12$ & $7.3 \mathrm{E}-12$ \\
\hline $\begin{array}{c}\text { Package contaminated } \\
\text { soil }\end{array}$ & $6.4 \mathrm{E}-7$ & $1.0 \mathrm{E}-7$ & $1.0 \mathrm{E}-7$ & $9.4 \mathrm{E}-10$ & $4.7 \mathrm{E}-10$ & $4.7 \mathrm{E}-10$ \\
\hline \hline
\end{tabular}

\footnotetext{
${ }^{\mathrm{a}} \mathrm{LAB}=$ laborer

${ }^{b} \mathrm{HEO}=$ heavy equipment operator

${ }^{c}$ SUP $=$ supervisor
} 


\section{ESTIMATION OF RADIONUCLIDE INTAKES AND DOSES}

Radioactive atoms undergo spontaneous nuclear transformations and release excess energy in the form of ionizing radiation. Such transformations are referred to as radioactive decay. As a result of the radioactive decay process, one element is transformed into another element. A radioactive species of a particular element is referred to as a radionuclide or radioisotope. Radiation is capable of transferring sufficient energy to atoms to remove electrons from the atom, a process called ionization. This ionization or energy transfer can be harmful to living tissues. The type of ionizing radiation emitted by a particular radionuclide depends on the nature of the nuclear transformation and may include emissions of alpha particles, electrons (beta particles), and neutrons. Each of these transformations may be accompanied by emissions of photons (gamma radiations or $\mathrm{x}$-rays). The radiations differ in their physical characteristics and in abilities to harm biological tissue (EPA 1989a), as described below:

- Alpha Particles have a mass of 4 and charge of 2, tending to ionize atoms quickly. Alpha particles will usually not penetrate an ordinary sheet of paper or the outer layer of skin. Alpha particles are a significant hazard only when emitted by radionuclides within the body, where their energy is absorbed by a small volume of tissue.

- Beta Particles are high-speed electrons emitted over a continuous energy spectrum. These particles are smaller than alpha particles and transfer their energy to tissue at a lower rate. Unshielded beta sources are potentially harmful if the radiation has enough energy and is within a few centimeters of exposed skin surfaces. Beta sources shielded with certain metallic materials may produce low energy $\mathrm{x}$-rays, which may contribute to external radiation exposure. Beta particles deposit much less energy than alpha particles to small volumes of tissue and inflict less internal damage per unit of energy.

- Gamma Radiations are photons emitted from the nucleus of a radioactive atom. X-rays, identical in form to gamma rays, are photons emitted from electron transitions. Both are forms of electromagnetic radiation, and both have a high penetration ability and are of most concern as external radiation hazards. 
- Neutronsare emitted during nuclear fission reactions, along with fission fragments and beta and gamma radiation. For radionuclides likely to be encountered at DOE or Superfund sites, the rate of spontaneous fission is minute and no significant neutron radiation is expected.

Quantities of radionuclides are expressed in terms of activity. The conventional unit of activity is the Curie (Ci), which is the quantity of a given radionuclide in which, on average, $3.7 \times 10^{10}$ atoms undergo spontaneous transformation each second. Environmental concentrations of radionuclides are often expressed in picoCuries (pCi). One $\mathrm{pCi}$ is equal to $10^{-12} \mathrm{Ci}$.

Ionizing radiation can cause adverse effects on tissues only when the energy released during radioactive decay is absorbed in tissue. The absorbed dose (D) is the mean energy imparted by ionizing radiation to a unit mass of tissue. The conventional unit of absorbed dose is the rad. At low levels of exposure, absorbed dose is not sufficient to relate the amount of energy absorbed to the biological effect (e.g., cancer induction). For the same absorbed dose delivered at the same rate, some types of radiation may produce more pronounced biological effects than others. Because absorbed dose is not sufficient to relate the relative effectiveness of radiation to biological effects, the concept of the dose equivalent $(\mathrm{H})$ was developed. The $\mathrm{H}$ is defined as the absorbed dose modified by a quality factor that represents the biological effects of the particular radiations emitted by a radionuclide. The $\mathrm{H}$ was developed to normalize the unequal biological effects produced from equal absorbed doses of different types of radiation. The conventional unit of the DE is the rem. The DE is defined as follows:

$$
H=D * Q
$$

where $\mathrm{H}=$ dose equivalent (rem),

$\mathrm{D}=$ absorbed dose (rad),

$\mathrm{Q}=$ quality factor (unitless).

Quality factors assigned by ICRP (1987) include values of $Q=20$ for alpha particles, $Q=10$ for neutrons and protons, and $Q=1$ for beta particles, positrons, $\mathrm{x}$-rays, and gamma rays. The $Q$ values for neutrons vary with energy. For example, $Q=3$ for $\mathrm{E}<10 \mathrm{keV}$, and $Q=10$ for $\mathrm{E}>10 \mathrm{keV}$. Other values of $Q$ are also appropriate if the energies are known more exactly. A $Q$ value of 20 means that if an equal amount of energy is absorbed, an alpha particle will inflict approximately 20 times more damage to biological tissue than a beta particle or gamma ray. While rad and rem are conventional units, the SI 
(international system) units of activity, absorbed dose, and DE are the Becquerel (Bq), Gray (Gy), and the Sievert (Sv), respectively. The relationship of these units is shown below:

$$
\begin{aligned}
& 1 \mathrm{~Bq}=2.7 \times 10^{-11} \mathrm{Ci} \\
& 1 \mathrm{Ci}=3.7 \times 10^{10} \mathrm{~Bq} \\
& 1 \mathrm{~Gy}=1 \text { joule } / \mathrm{kg}=100 \mathrm{rad} \\
& 1 \mathrm{rad}=0.01 \mathrm{~Gy}=0.01 \text { joule } / \mathrm{kg} \\
& 1 \mathrm{~Sv}=100 \mathrm{rem}
\end{aligned}
$$

When subjected to equal doses of radiation, organs and tissues have different cancer induction rates. To normalize radiation doses and effects on a whole body basis, the EDE is used. The EDE is defined as the weighted sum of the dose equivalents to different organs or tissues. Weighting factors are the ratios of risk for a given tissue to total risk for all tissues when the body is irradiated uniformly. Weighting factors for different organs or tissues used in defining EDE (ICRP 1977) follow:

$\begin{array}{lc}\text { Gonads } & 0.25 \\ \text { Breast } & 0.15 \\ \text { Red marrow } & 0.12 \\ \text { Lungs } & 0.12 \\ \text { Thyroid } & 0.03 \\ \text { Bone surfaces } & 0.03 \\ \text { Remainder } & 0.3\end{array}$

The weighting factor for gonads represents stochastic risk of hereditary effects, but all other weighting factors represent stochastic risk of fatal cancers. The EDE can be defined as:

$$
E D E=\sum_{T=1}^{n} W_{T} * H_{T},
$$


where $\mathrm{EDE}=$ effective dose equivalent (rem),

$W_{T}$ = weighting factor for organ or tissue $T$,

$\mathrm{H}_{\mathrm{T}} \cdot=$ dose equivalent to organ or tissue $\mathrm{T}(\mathrm{rem})$,

$\mathrm{n} \quad=$ total number of organs or tissues.

EDEs due to inhalation and ingestion may be determined from radionuclide concentrations in environmental media by multiplying the radionuclide concentration by the duration of exposure, intake per unit time, and the dose conversion factor (DCF), which represents the dose equivalent per unit intake. Internal DCFs are available from Federal Guidance Report No. 11 (EPA 1988e). These DCFs give the 50-yr committed dose from an acute intake (section 6.1).

Although ICRP 60 (1990) is a more recent revision of the ICRP guidance, ICRP 26 tissue weighting factors and risk values are still widely in use. Since DOE has not adopted ICRP 60 weighting factors, this methodology uses ICRP 26 tissue weighting factors in conjunction with ICRP 60 risk factors. The combination of these two ICRP methods has also been used in the Idaho National Engineering Laboratory's Spent Fuel Environmental Impact Statement (INEL 1994).

Radionuclide releases to the environment may occur by particulate suspension due to wind erosion, mechanical activities, process emissions, volatilization, or direct radiation. The primary modes of exposure for ER workers are inhalation, ingestion of contaminated soil, and direct radiation. Radionuclide releases in a WM facility may occur from surface contamination on waste containers, leaks in the piping, ventilation, or filtering systems, and direct irradiation from waste processing. The primary modes of exposure for WM workers are inhalation and direct radiation.

\subsection{Internal Exposure}

Internal exposure refers to the irradiation of human tissues by radiation emitted from radionuclides that are ingested or inhaled. All types of radiation may contribute to internal exposure. For internal exposure, intakes of radionuclides commit the individual to receiving doses over future times, even with no further intakes. The source of radiation is eventually removed from the body by biological elimination or radioactive decay. Internal doses to tissues are usually reported in terms of 50-yr committed DEs, the total 
$\mathrm{DE}$ (received by the tissue) over the 50 -yr period following the intake of a radionuclide. Internal doses are calculated here as $\mathbf{5 0}$-yr committed effective dose equivalents (CEDE).

Internal radiation is considered for individuals exposed to radionuclides that are systemically incorporated into the body by ingestion or inhalation. The radiation dose is determined from the quantity of radionuclide ingested or inhaled, depending on which exposure route is being evaluated.

\subsubsection{INHALATION OF RADIONUCLIDES}

The following forms of radionuclides may be inhaled:

- Particulate radionuclides,

- Vapor phase radionuclides (e.g., tritium), and

- Gas phase radionuclides (e.g., radon).

As described in chapter 5, measured air contaminant concentrations due to remedial and TSD activities are not available at some sites. Air concentrations are calculated based on whether the source is located indoors or outdoors and whether it is an area or point source.

\subsubsection{Air Concentration Estimation Methods}

EPA default emission rates adjusted for specific activities estimated, emission rates or generic emission rates (listed in chapter 5) can be used to estimate the amount of radionuclide material airborne per given time. Once emission rates are established, the radionuclide air concentrations at worker locations are calculated using the models described in section 5.1.2.

\subsection{Particulate Radionuclides}

Particulate radionuclides can become suspended due to wind erosion, soil handling activities, and process emissions. The estimation method for particulate air concentration of chemicals is also applicable to 
estimation of particulate air concentration of radionuclides since it is the amount of soil that becomes airborne per time. When measured, site-specific and technology-specific emission rates are unavailable, generic emission rates can be used to calculate radionuclide particulate concentrations in air.

Mass loading factors and resuspension factors are alternative methods of estimating air concentrations. Resuspension factors are ratios of the contaminant concentration in air to the contaminant concentration on a surface. The mass loading concept attempts to circumvent the details of soil characteristics and the resuspension process and to relate the measured soil concentration of the contaminant to the mass of soil particulates in the air (Hanson 1980). Two parameters, the dust loading in the atmosphere and the contaminant concentration in soil, are needed to provide estimates by this method as described elsewhere (Hanson 1980).

\subsection{Vapor And Gas Phase Radionuclides}

Tritium $\left({ }^{3} \mathrm{H}\right)$ and radon $\left({ }^{20} \mathrm{Rn}\right.$ and $\left.{ }^{20} \mathrm{Rn}\right)$ are handled differently in risk assessments than most other radionuclides, which are generally treated as particulates (NRC 1977). Tritiated water and its vapor can be ingested, inhaled, or dermally absorbed. Tritiated water can be released from open bodies of water or contaminated soil. Retention of tritium is dependent on its chemical form when it enters the body. In this methodology, evaporation rates applicable to water vapor can be used to estimate tritiated water vapor air concentrations. For example, evaporation of water from a circular pool can be calculated as follows:

$$
E=\frac{\left(20.73 * A^{0.9} * P_{s} * U^{0.8}\right)}{T^{1.47}}
$$

where $E=$ evaporation rate of water $(\mathrm{g} / \mathrm{s})$,
$A=$ surface area of pool $\left(\mathrm{m}^{3}\right)$,
$\mathrm{P}_{\mathrm{s}}=$ equilibrium vapor pressure of water at ambient temperature,
$\mathrm{U}=$ windspeed $(\mathrm{m} / \mathrm{s})$,
$\mathrm{T}=$ absolute temperature (K). 
This equation assumes that water and air are at the same temperature, ignoring the evaporative cooling that tends to reduce the vapor pressure and evaporation rate (EPA 1993). To calculate the emission rate of tritium, the evaporation rate is multiplied by the specific activity of tritium in water as follows:

$$
R=E * a,
$$

where $\mathbf{R}=$ emission rate of tritium $(\mathrm{pCi} / \mathrm{s})$,

$a=$ specific activity of tritium in pool water $(\mathrm{pCi} / \mathrm{g})$.

If water contaminated by tritium has been spilled or released to the soil, other methods of estimating emissions are used. According to EPA (EPA 1988a), if liquid pools are visible on the soil surface or if the soil is saturated, the emission rate should be calculated for open liquid pools. If subsurface soil is contaminated but surface soil is dry and uncontaminated by tritium, the following equation can be used to calculate a more realistic emission rate:

$$
E_{i}=D_{i} * C_{s i} * A\left(P_{t}^{4 / 3}\right) * \frac{M_{i}}{d_{s c}}
$$

where $\mathrm{E}_{\mathrm{i}}=$ emission rate of component $i(\mathrm{~g} / \mathrm{s})$,

$\mathrm{D}_{\mathrm{i}}=$ diffusion coefficient of component $i$ in air $\left(\mathrm{cm}^{2} / \mathrm{s}\right)$,

$\mathrm{C}_{\mathrm{si}} \quad=$ saturation vapor concentration of component $i\left(\mathrm{~g} / \mathrm{cm}^{3}\right)$,

A $=$ exposed area $\left(\mathrm{cm}^{2}\right)$,

$P_{\mathrm{t}} \quad=$ total soil porosity (dimensionless),

$\mathrm{M}_{\mathrm{i}} \quad$ = mole fraction of toxic component $i$ in the waste (gmole/gmole),

$\mathrm{d}_{\mathrm{sc}} \quad=$ effective depth of soil cover $(\mathrm{cm})$.

In cases where ${ }^{222} \mathrm{Rn}$ fluence rates must be estimated, the Regulatory Guide 3.64, Calculation of Radon Flux Attenuation by Earthen Uranium Mill Tailing Covers, developed by the NRC (1989), may be useful. This fluence rate can then be compared to the regulatory limit of $20 \mathrm{pCi} / \mathrm{cm}^{2} / \mathrm{s}$ (40 CFR 191) and used to estimate radon concentrations above the pile and worker risk from exposure to these concentrations. 
Doses from exposure to ${ }^{22} \mathrm{Rn}$ progeny is based on the ${ }^{22} \mathrm{Rn}$ concentration and the ${ }^{22} \mathrm{Rn}$ progeny equilibrium fraction. The NRC Regulatory Guide 3.59 (NRC 1987) provides methods, models, data, and assumptions that can be used to estimate airborne emissions of radioactive and toxic materials from various steps in uranium milling processes, with particular attention given to emission rates from tailings piles. Many of these processes and methods are applicable to other ER and WM processes as well. Methods are given for estimating particulate emission rates for ore processing and windblown emissions. Methods for estimating radon emission rates are provided for storage, crushing, grinding, and tailing disposal sites.

\subsubsection{Inhalation Intakes And EDE Estimation}

Radionuclide air concentrations (either known or estimated) are used to estimate intakes and doses. Intake of radionuclides via the inhalation route is estimated as shown in the following equation:

$$
I=I_{h} R * A C * E D * E T * E F,
$$

where $\mathrm{I}=$ contaminant-specific individual intake from breathing contaminated air (pCi),

$I_{\mathrm{b}} \mathrm{R}=$ inhalation rate for individuals $\left(\mathrm{m}^{3} / \mathrm{hr}\right)$,

$\mathrm{AC}=$ contaminant-specific air concentration $\left(\mathrm{pCi} / \mathrm{m}^{3}\right)$,

$\mathrm{ED}=$ exposure duration (yr),

ET = exposure time $(\mathrm{hr} / \mathrm{d})$,

$E F=$ exposure frequency $(\mathrm{d} / \mathrm{yr})$.

For radionuclides, the intake $(\mathrm{pCi})$ is used to estimate an EDE. EDEs due to inhalation can be estimated as follows:

$$
E D E=I * D C F_{i h} * 3.7,
$$


where: $\mathrm{EDE} \quad=$ effective dose equivalent (rem),

$\mathrm{DCF}_{\text {ih }}$ = inhalation dose conversion factor (Sv/Bq) (EPA 1989b),

3.7 = units conversion factor $(\mathrm{rem}-\mathrm{Bq} / \mathrm{Sv}-\mathrm{pCi})$.

\subsubsection{INGESTION OF RADIONUCLIDES}

Ingestion of radionuclides may occur when workers are exposed to contaminants by mechanical agitation, wind-generated dust, or by ingesting soil that is on their skin. It is assumed that workers are wearing the appropriate protective clothing and/or equipment for the specific activity and are adhering to safe working practices; thus, the risk of ingesting the hazardous contaminants is minimized. Intake of radionuclides via the ingestion route is estimated as shown in the following equation:

$$
I=I R_{g} * S C * F I * E F * E D * E T,
$$

$$
\begin{aligned}
& \text { where I = intake from ingestion of contaminated soil ( } \mathrm{pCi}) \text {, } \\
& \mathrm{SC}=\text { concentration of the radionuclide in soil }(\mathrm{pCi} / \mathrm{g}) \text {, } \\
& \mathrm{IR}_{\mathrm{g}}=\text { ingestion rate }(\mathrm{g} / \mathrm{hr}) \text {, } \\
& \mathrm{EF} \quad=\text { exposure frequency }(\mathrm{d} / \mathrm{yr}) \text {, } \\
& \text { FI = fraction ingested, } \\
& \mathrm{ED}=\text { exposure duration (yr), } \\
& \mathrm{ET}=\text { exposure time }(\mathrm{hr} / \mathrm{d}) \text {. }
\end{aligned}
$$

The fraction ingested $(0.4)$ is assumed as a most conservative, worst-case value. For radionuclides, the ingestion intake values are used to estimate an EDE. The EDE can be estimated as follows:

$$
E D E=I * D C F_{i g} * 3.7
$$


where: $\mathrm{EDE}=$ effective dose equivalent (rem),

$\mathrm{DCF}_{\mathrm{iB}}=$ the ingestion conversion factor (Sv/Bq)(EPA 1988b),

3.7 = units conversion factor (rem-Bq/Sv-pCi).

EDEs for radionuclides are used to determine cancer incidence, cancer fatalities, and adverse genetic effects.

\subsection{External Exposure}

External exposure refers to the irradiation of a receptor by radiation sources external to the body. The most important modes of external exposure for radionuclides in the environment are immersion in air containing gamma-emitting radionuclides and exposure to contaminated surface soil or equipment surfaces. For WM, direct radiation exposures to waste and waste containers are common during handling and treatment activities. Immersion in contaminated air is an exposure route considered for accidents involving releases of radionuclides. Only radiations that penetrate the body surface (photons, beta, and neutron radiations) contribute significantly to external exposure, with gamma-emitters being the most prevalent.

External radiation is considered for exposed to land or equipment surfaces contaminated by radionuclides or to radionuclides in the waste handled by TSD workers. When actual exposure rate data are unknown or unavailable, computer codes or other, more simplistic methods may be used to estimate the EDE rates attributed to direct radiation. Some of these methods include PATHRAE (EPA 1987b) and PRESTO, EPA models for estimating exposure to low-level radiation. For this methodology, the MicroShield code (Grove Engineering 1992) was chosen because it is user-friendly, has many geometries, and includes widely applicable equations that are automated, eliminating the error inherent in calculating complicated equations manually. MicroShield uses a Gaussian numerical signature method to integrate the point kernel equation to estimate photon fluence rates and ICRP 51 (ICRP 1987) methods to estimate EDE rates. MicroShield uses information such as source-to-receptor distances, number and type of shielding materials, and source geometry in its calculations. The following sections describe some of the parameters necessary for estimating EDE rates using MicroShield. 


\subsubsection{SOURCE GEOMETRIES}

Source geometries describe a radiation problem using geometric configurations within which a worker may be located. These geometrical descriptions of radiation problems make exposure considerations such as distances, source volume, and shielding easier to visualize and manipulate. The geometry includes the distance and orientation between source and dose point, dimensions of the source region, and the dimensions, locations, and orientations of intervening shields (Grove Engineering 1992). MicroShield contains solution algorithms for the geometries listed in table 6.2-1. In addition to the shields listed in the table, air shields and transition shields are also considered.

Table 6.2-1. MicroShield Geometries

\begin{tabular}{|ll||}
\hline \multicolumn{1}{|c|}{ Source Geometry } & \multicolumn{1}{c|}{ Possible Shields } \\
\hline Point & Slabs \\
Line & Slabs, immersion \\
Disk & Slabs \\
Rectangular area - vertical & Slabs \\
Rectangular area - horizontal & Slabs \\
Sphere & Slabs, immersion \\
Cylinder volume - shields at the side & Cylindrical, clad, transition, slabs \\
Cylinder volume - shields at the end & Slabs, immersion \\
Cylinder surface - internal dose point & Immersion \\
Cylinder surface - external dose point & Cylindrical, clad, transition, slabs \\
Rectangular volume & Slab, immersion \\
Truncated cone & Slab \\
Infinite plane & Slab \\
Infinite slab & Slab \\
\hline
\end{tabular}

Source: Grove Engineering 1992. 


\subsubsection{SHIELDS}

Each source geometry shown in table 6.2-1 could include shielding that would further protect workers from exposure to radiation. Examples of the main shielding types are as follows:

- Air gaps,

- Transition shields,

- Slab shields,

- End clad and side clad shields,

- Immersion shields.

An air gap is a shield region with air as the shielding material. Air gaps are usually present when shield thicknesses are less than the total source-to-receptor distance. Transition shields determine which shields are cylindrical or spherical. Spherical and cylindrical sources may have shields of the same geometry, respectively. The transition between the inner spherical or cylindrical shield and the outer slab shields is called the transition shield. End and side clad shields are used for cylindrical sources; they are materials that wrap around the source. Finally, immersion shields are present when a line of sight between the exposure point (or dose point) and part of the source is immersed in a medium separate from the specified shields. Immersion shields can exist for sources that are lines, cylinders, and horizontal areas (Grove Engineering 1992).

Shielding materials affect the efficacy of the protection provided by the shielding. Attenuation and scattering of radiation between a source and exposure point are affected by all intervening materials. Shield materials determine the radiation attenuation and buildup characteristics used to calculate the dose rate ( $\mathrm{rad} / \mathrm{hr}$ ) (Grove Engineering 1992). A variety of source geometries are used to estimate worker exposures. A range of source geometries is assumed for ER operations involving above- and below-ground tanks, drums, landfills, trenches, ion exchange columns, and equipment. For example, a drum may be modeled as a cylinder with side shields.

For ER, source-to-receptor distances vary among workers and often with each task. For laborers, the source-to-receptor distance is assumed to be $1 \mathrm{~m}$ (1.1 yd)(i.e., the laborer is standing above the source type), unless the activity requires closer distances (e.g., drum handling). Heavy equipment operator source-to-receptor distances are based on equipment type and dimensions, if available, or it is assumed that 
the operator is located approximately $2 \mathrm{~m}(2.2 \mathrm{yd})$ from the source, with shielding of $1 / 4$-inch-thick steel representing the construction vehicle's cab thickness.

WM worker environments and shielding configurations comprise two categories: waste handling and treatment facility operations. Waste handling can occur indoors or outdoors and involves such activities as retrieving containers (cylinder source) from storage, unloading containers from trucks, and placing containers in storage or disposal. During handling activities, workers may be in close proximity to the waste containers, or they may use cranes or remotely operated equipment to handle containers of high activity waste.

During treatment facility operations, workers are responsible for operating the various machines and process equipment necessary to treat the waste. In keeping with the conceptual WM facility and module designs, it is assumed that workers are located in operating "galleries." An operating gallery is a room in the treatment facility, located separately from those rooms in which waste processing occurs. Operating galleries contain the treatment process controls and viewing windows and/or video screens that allow workers to observe the treatment process. The amount of worker protection provided by the operating galleries varies depending on the type of waste being treated. For example, concrete shielding walls (slab shields) and airlocks may be present to minimize external and internal radiation exposure.

\subsubsection{DIRECT Radiation Dose Estimation}

MicroShield uses shielding and material density information, along with other parameters such as buildup factors, energy levels, and fluence rates (i.e., energy/time that crosses an area at right angles to a beam of radiation) to estimate the EDE rate received by a receptor at an exposure point. The EDE rate estimated for rotational geometry is used in this methodology. The rotational EDE is the dose that the worker would receive if rotated $360^{\circ}$ at constant angular velocity at a fixed distance from the stationary source.

Once representative EDE rates are estimated, the dose can be estimated as follows:

Collective Dose $=E D E$ rate $* E D * N W$, 
where: EDE rate $=$ dose rate $(\mathrm{mrem} / \mathrm{hr})$,

ED $=$ exposure duration (hr).

\subsection{Example Exposure Quantification: Radionuclide}

An example calculation of EDEs received from exposure to a hypothetical radioactively contaminated site is shown below. The calculated EDEs are from external radiation, inhalation, and ingestion exposure routes. The site being remediated is a region of four contaminated soil plots that are $10 \mathrm{~m}$ (11 yd) long, $10 \mathrm{~m}$ (11 yd) wide, and $3 \mathrm{~m}$ (3.3 yd) deep, with an inventory of $1 \times 10^{4} \mathrm{pCi} / \mathrm{g}$ of ${ }^{137} \mathrm{Cs}$. The inventory was measured twenty-five years ago. When decayed for 25 years, the inventory becomes $5.63 \times 10^{3} \mathrm{pCi} / \mathrm{g}$ of ${ }^{137} \mathrm{Cs}$ and $5.33 \times 10^{3} \mathrm{pCi} / \mathrm{g}$ of ${ }^{137 \mathrm{~m}} \mathrm{Ba}$. These inventories were calculated by MicroShield when $1 \times 10^{4} \mathrm{pCi}$ of ${ }^{137} \mathrm{Cs}$ was decayed for 25 years. Each plot is surrounded by sheet metal that extends $0.46 \mathrm{~m}(1.5 \mathrm{ft})$ into the ground and $0.61 \mathrm{~m}(2 \mathrm{ft})$ above the ground.

The remediation alternative illustrated is capping the contaminated region with a concrete and clay cap. This remediation technology can be further divided into the following activities: construct $1 \mathrm{~m}$ (1.1 yd) deep cutoff wall, construct $15 \mathrm{~cm}$ (6 in) concrete slab, rough grade fill, cover site with clay, cover site with sand, cover site with geomembrane, cover site with geotextile, cover site with topsoil, and seed and plant area. The EDEs attributed to each of these activities are evaluated for two worker types, laborers and heavy equipment operators, wearing level D PPE.

For each activity involving direct radiation exposure, shielding assumptions must be made. Laborers and any workers not operating heavy equipment are assumed to have a $1 \mathrm{~m}(1.1 \mathrm{yd})$ air shield. This represents the distance from the last shield associated with the source to the torso (and vital organs) of the worker. Heavy equipment operators are assumed to have a $1 \mathrm{~m}$ (1.1 yd) air shield, a $0.01 \mathrm{~m}$ (4 in) steel shield (the thickness of the frame and cab of the dozer), and a $0.5 \mathrm{~m}(1.7 \mathrm{ft}$ ) air shield (the distance from the floor of the equipment to the operator's torso). These thicknesses and dimensions represent the average dimensions and thicknesses of heavy equipment used in earth moving activities.

Use of the steel and soil shielding in this example is based on several assumptions. Steel, which is approximately $98 \%$ iron and has a density of $7.88 \mathrm{~g} / \mathrm{cm}^{3}$, is modeled as iron. The density of pure iron is $7.86 \mathrm{~g} / \mathrm{cm}^{3}$. As far as possible, the typical elemental composition of soil is used to model a shield of soil 
in MicroShield (Vilenskii 1960). MicroShield uses the elemental composition of soil to compute the effective atomic number for soil. MicroShield then uses the effective atomic number to interpolate buildup factors to be used for soil. The average composition of soil (based on weight) used in this example is as follows (Vilenskii 1960):

$\begin{array}{ll}\text { Aluminum } & 7.1766 \% \\ \text { Calcium } & 1.379 \% \\ \text { Carbon } & 2.0131 \% \\ \text { Iron } & 3.8249 \% \\ \text { Magnesium } & 0.6039 \% \\ \text { Oxygen } & 49.3206 \% \\ \text { Potassium } & 1.3689 \% \\ \text { Silicon } & 33.2159 \% \\ \text { Sodium } & 0.6341 \% \\ \text { Titanium } & 0.463 \%\end{array}$

MicroShield allows only 10 constituents to be used when defining the composition of a shield. The most abundant constituents were selected, and MicroShield normalized the weight percentages so that the total equals $100 \%$. The percentages listed above are the normalized percentages. Shielding and personnel assumptions for each subactivity are shown in table 6.3-1. 
Table 6.3-1. Shielding and Personnel Assumptions for Example Site

\begin{tabular}{|c|c|c|c|c|}
\hline Activity & $\begin{array}{l}\text { Number } \\
\text { of } \\
\text { Laborers }\end{array}$ & $\begin{array}{c}\text { Shielding for } \\
\text { Laborers }\end{array}$ & $\begin{array}{c}\text { Number of } \\
\text { Heavy } \\
\text { Equipment } \\
\text { Operators }\end{array}$ & $\begin{array}{l}\text { Shielding for Heavy } \\
\text { Equipment Operators }\end{array}$ \\
\hline Construction of cutoff wall & 2 & $1 \mathrm{~m}$ air & 2 & $\begin{array}{c}1 \mathrm{~m} \text { air, } 1 \mathrm{E}-2 \mathrm{~m} \text { steel, } 0.5 \\
\mathrm{~m} \text { air }\end{array}$ \\
\hline $\begin{array}{l}\text { Construction of concrete } \\
\text { slab }\end{array}$ & 6 & $1 \mathrm{~m}$ air & 2 & $\begin{array}{c}7.6 \mathrm{E}-2 \mathrm{~m} \text { concrete, } 1 \mathrm{~m} \\
\text { air, } 1 \mathrm{E}-2 \mathrm{~m} \text { steel, } 0.5 \mathrm{~m} \\
\text { air }\end{array}$ \\
\hline Rough grade fill & 3 & $\begin{array}{c}0.15 \mathrm{~m} \text { concrete, } 1 \\
\mathrm{~m} \text { air }\end{array}$ & 1 & $\begin{array}{c}1.5 \mathrm{E}-1 \mathrm{~m} \text { concrete, } 1 \mathrm{~m} \\
\text { air, } 1 \mathrm{E}-2 \mathrm{~m} \text { steel, } 0.5 \mathrm{~m} \\
\text { air }\end{array}$ \\
\hline Cover region with clay & 3 & $\begin{array}{c}0.15 \mathrm{~m} \text { concrete, } 1 \\
\mathrm{~m} \text { air }\end{array}$ & 1 & $\begin{array}{l}1.5 \mathrm{E}-1 \mathrm{~m} \text { concrete, } 1 \mathrm{~m} \\
\text { air, } 1 \mathrm{E}-2 \text { steel, } 0.5 \mathrm{~m} \text { air }\end{array}$ \\
\hline Cover region with sand & 4 & $\begin{array}{c}0.15 \mathrm{~m} \text { concrete, } 1 \\
\mathrm{~m} \text { air }\end{array}$ & 2 & $\begin{array}{l}\text { 1.5E-1 } \mathrm{m} \text { concrete, } 0.5 \mathrm{~m} \\
\text { soil, } 1 \mathrm{~m} \text { air, } 1 \mathrm{E}-2 \mathrm{~m} \\
\text { steel, } 0.5 \mathrm{~m} \text { air }\end{array}$ \\
\hline Cover with geomembrane & 4 & $\begin{array}{l}0.15 \mathrm{~m} \text { concrete, } \\
0.5 \mathrm{~m} \text { soil, } 1 \mathrm{~m} \text { air }\end{array}$ & 2 & $\begin{array}{l}\text { 1.5E-1 } \mathrm{m} \text { concrete, } 0.5 \mathrm{~m} \\
\text { soil, } 1 \mathrm{~m} \text { air, } 1 \mathrm{E}-2 \mathrm{~m} \\
\text { steel, } 0.5 \mathrm{~m} \text { air }\end{array}$ \\
\hline Cover with geotextile & 3 & $\begin{array}{c}0.15 \mathrm{~m} \text { concrete, } 1 \\
\mathrm{~m} \text { soil, } 1 \mathrm{~m} \text { air }\end{array}$ & 1 & $\begin{array}{l}\text { 1.5E- } 1 \mathrm{~m} \text { concrete, } 1 \mathrm{~m} \\
\text { soil, } 1 \mathrm{~m} \text { air, } 1 \mathrm{E}-2 \mathrm{~m} \\
\text { steel, } 0.5 \mathrm{~m} \text { air }\end{array}$ \\
\hline Cover region with topsoil & 4 & $\begin{array}{l}1.5 \mathrm{E}-1 \mathrm{~m} \text { concrete, } \\
1 \mathrm{~m} \text { soil, } 1 \mathrm{~m} \text { air }\end{array}$ & 2 & $\begin{array}{l}1.5 \mathrm{E}-1 \mathrm{~m} \text { concrete, } 1 \mathrm{~m} \\
\text { soil, } 1 \mathrm{~m} \text { air, } 1 \mathrm{E}-2 \mathrm{~m} \\
\text { steel, } 0.5 \mathrm{~m} \text { air }\end{array}$ \\
\hline Seeding and planting & 4 & $\begin{array}{c}1.5 \mathrm{E}-1 \mathrm{~m} \text { concrete, } \\
1 \mathrm{~m} \text { soil, } 1 \mathrm{~m} \text { air }\end{array}$ & 0 & N/A \\
\hline
\end{tabular}

Based on these shielding assumptions and site dimensions and a decay time of 25 years, MicroShield calculates an EDE rate using rotational geometry. The EDE rates for each of the subactivities are shown below in table 6.3-2. By multiplying the EDE rates by the number of person-hrs spent on each activity, the population EDE (person-rem) is obtained. 
Table 6.3-2. EDEs for Each Activity for Direct Radiation

\begin{tabular}{|c|c|c|c|c|c|c|c|c|c|}
\hline & $\begin{array}{c}\text { Cutoff } \\
\text { wall }\end{array}$ & $\begin{array}{c}\text { Concrete } \\
\text { slab }\end{array}$ & $\begin{array}{c}\text { Rough } \\
\text { grade } \\
\text { fil }\end{array}$ & $\begin{array}{l}\text { Clay } \\
\text { cover }\end{array}$ & $\begin{array}{l}\text { Sand } \\
\text { cover }\end{array}$ & $\begin{array}{c}\text { Geomembran } \\
\mathbf{e}\end{array}$ & Geo-textile & $\begin{array}{l}\text { Topsoil } \\
\text { cover }\end{array}$ & $\begin{array}{l}\text { Seed } \\
\text { and } \\
\text { plant }\end{array}$ \\
\hline $\begin{array}{l}\mathrm{LAB}^{\mathrm{a}} \mathrm{EDE} \\
\text { rate } \\
(\mathrm{mrem} / \mathrm{hr})\end{array}$ & 2.04 & 2.0 & $1.1 E-1$ & $1.1 \mathrm{E}-1$ & $7.0 \mathrm{E}-4$ & $7.0 E-4$ & $3.6 \mathrm{E}-6$ & $3.6 \mathrm{E}-6$ & $3.6 \mathrm{E}-6$ \\
\hline $\begin{array}{l}\text { HEO'b EDE } \\
\text { rate } \\
(\mathrm{mrem} / \mathrm{hr})\end{array}$ & $7.6 \mathrm{E}-1$ & 7.6E-1 & $6.5 \mathrm{E}-2$ & $6.5 \mathrm{E}-2$ & $4.0 \mathrm{E}-4$ & $4.0 \mathrm{E}-4$ & $2.0 \mathrm{E}-6$ & $2.0 \mathrm{E}-6$ & N/A \\
\hline $\begin{array}{l}\text { LAB } \\
\text { Person-hrs }\end{array}$ & 13 & 205.5 & 6 & 8.3 & 2.7 & 26.7 & 15 & 6 & 3 \\
\hline $\begin{array}{l}\text { HEO } \\
\text { person-hrs }\end{array}$ & 13 & 68.5 & 2 & 2.8 & 1.3 & 13.3 & 5 & 3 & N/A \\
\hline $\begin{array}{l}\text { LAB EDE } \\
\text { (rem) }\end{array}$ & $2.7 \mathrm{E}-2$ & $4.2 \mathrm{E}-1$ & $6.8 \mathrm{E}-4$ & $9.4 E-4$ & $1.9 \mathrm{E}-6$ & $1.9 \mathrm{E}-5$ & $5.4 \mathrm{E}-8$ & $2.2 \mathrm{E}-8$ & $1.1 \mathrm{E}-8$ \\
\hline $\begin{array}{l}\text { HEO EDE } \\
\text { (rem) }\end{array}$ & $9.9 \mathrm{E}-3$ & $5.2 \mathrm{E}-2$ & $1.3 \mathrm{E}-4$ & $1.8 \mathrm{E}-4$ & $5.2 \mathrm{E}-7$ & $5.3 \mathrm{E}-6$ & $1 E-8$ & $6 \mathrm{E}-9$ & N/A \\
\hline
\end{tabular}

a Laborer

${ }^{b}$ Heavy Equipment Operator

Inhalation and ingestion of radionuclides apply only to the construction of the cutoff wall and the concrete slab since these activities involve dust generation from disturbing and removing the contaminated soil. To obtain risk estimates for inhalation of ${ }^{137} \mathrm{Cs}$ and ${ }^{137 m} \mathrm{Ba}$, the PAL model is used to estimate air concentrations. The emission rates used are $2.62 \mathrm{E}-4 \mathrm{~g} / \mathrm{s}$ for construction of the cutoff wall and $1.09 \mathrm{E}-4$ $\mathrm{g} / \mathrm{s}$ for construction of the concrete slab. Substituting the appropriate values into equation 5.9 , the source strengths are then estimated as follows:

$$
S S=\frac{C * E R}{100},
$$

where SS = source strength $\left(\mathrm{pCi} / \mathrm{m}^{2}-\mathrm{s}\right)$,

$\mathrm{C}=$ soil concentration $(\mathrm{pCi} / \mathrm{g})$, 
ER = emission rate (2.62E-4 $\mathrm{g} / \mathrm{s}$ and $1.09 \mathrm{E}-4 \mathrm{~g} / \mathrm{s}$ as described above),

$100=$ area of $100 \mathrm{~m}^{2}$ (length and width of source area are both $10 \mathrm{~m}$ ).

The source strengths for construction of the cutoff wall and construction of the concrete slab are 1.69E-16 and 7.05E-17 pCi/m $\mathrm{m}^{2}$-s for ${ }^{137} \mathrm{Cs}$ and $2.59 \mathrm{E}-23$ and $1.08 \mathrm{E}-23$ for ${ }^{137 \mathrm{~m}} \mathrm{Ba}$, respectively. To estimate contaminant air concentration for each subactivity, the PAL model requires that the source strength be in units of $\mathrm{g} / \mathrm{m}^{2}-\mathrm{s}$; therefore, the source strength is converted to these units by dividing by the ${ }^{137} \mathrm{Cs}$ or ${ }^{137 \mathrm{~m}} \mathrm{Ba}$ specific activity ( 87 or $5.38 \mathrm{E} 8 \mathrm{Ci} / \mathrm{g}$, respectively). The air concentrations obtained from PAL using these source strengths, a wind speed of $2 \mathrm{~m}(2.2 \mathrm{yd}) / \mathrm{s}$, a receptor height of $1.5 \mathrm{~m}$ $\left(1.7 \mathrm{yd}\right.$ ), and the diagonal configuration are (for ${ }^{137} \mathrm{Cs}$ ) $1.57 \mathrm{E}-16$ and $6.55 \mathrm{E}-17 \mathrm{~g} / \mathrm{m}^{3}$ for construction of the cutoff wall and construction of the concrete slab, respectively. For ${ }^{137 \mathrm{~m}} \mathrm{Ba}$, the air concentrations are 2.41E-23 for construction of cutoff wall and 1.00E-23 for construction of the slab, respectively. The resulting air concentrations are then converted back to proper units $\left(\mathrm{pCi} / \mathrm{m}^{3}\right)$ using the specific activity.

The resulting air concentrations $\left({ }^{137} \mathrm{Cs}: 1.36 \mathrm{E}-2\right.$ and $5.70 \mathrm{E}-3 \mathrm{pCi} / \mathrm{m}^{3}$ and ${ }^{137 \mathrm{~m}} \mathrm{Ba}: 1.30 \mathrm{E}-2$ and $5.38 \mathrm{E}-3 \mathrm{pCi} / \mathrm{m}^{3}$ for construction of the cutoff wall and construction of the concrete slab, respectively), are compared to regulatory limits (DACs) to ensure that the air concentrations meet regulatory requirements and are then substituted into equation 6.3 to obtain the inhalation intake of ${ }^{137} \mathrm{Cs}$ and ${ }^{137 \mathrm{~m}} \mathrm{Ba}$. The $\mathrm{DAC}$ for ${ }^{137} \mathrm{Cs}$ is $7.0 \mathrm{E} 4 \mathrm{pCi} / \mathrm{m}^{3}$, far above the estimated air concentration; however, there is no DAC for ${ }^{137 m} \mathrm{Ba}$, so it is not compared to these limits. The inhalation rate for the laborer is assumed to be $2.5 \mathrm{~m}^{3} / \mathrm{hr}$, representing a moderate activity level, whereas the inhalation rate for the heavy equipment operator is $0.8 \mathrm{~m}^{3} / \mathrm{hr}$, representing a lighter activity level. Then, equation 6.7 is used to obtain the inhalation EDE, where the inhalation DCF is $8.63 \mathrm{E}-9 \mathrm{~Sv} / \mathrm{Bq}$ for ${ }^{137} \mathrm{Cs}$ and $3.04 \mathrm{E}-13$ for ${ }^{137 \mathrm{~m}} \mathrm{Ba}$.

Ingestion intake of ${ }^{137} \mathrm{Cs}$ and ${ }^{137 \mathrm{~m}} \mathrm{Ba}$ can be calculated by multiplying the proper soil concentration by the ingestion rate $(0.06 \mathrm{~g} / \mathrm{hr})$, the number of person-hours, and the fraction ingested $(0.4)$, as shown in equation 6.8. The ingestion EDE can be calculated using equation 6.9. The ingestion DCFs are 1.35E-8 Sv/Bq for ${ }^{137} \mathrm{Cs}$ and $6.89 \mathrm{E}-13 \mathrm{~Sv} / \mathrm{Bq}$ for ${ }^{137 \mathrm{~m}} \mathrm{Ba}$. The EDEs for the two activities are shown in table 6.3-3. 
Table 6.3-3. EDEs for ${ }^{137} \mathrm{Cs}$ and ${ }^{137 m} \mathrm{Ba}$ via Inhalation and Ingestion Routes

\begin{tabular}{|l|c|c|c|c||}
\hline \multicolumn{2}{|c|}{ Endpoints } & \multicolumn{2}{|c|}{ Construction of Cutoff Wall } & \multicolumn{2}{c|}{ Construction of Concrete } \\
& \multicolumn{2}{|c|}{ Slab } \\
\cline { 2 - 5 } & Inhalation & Ingestion & Inhalation & Ingestion \\
\hline LAB Person-hrs & 13 & 13 & 206 & 205.5 \\
\hline HEO Person-hrs & 13 & 13 & 68.5 & 68.5 \\
\hline LAB Intake (pCi) of ${ }^{137} \mathrm{Cs}$ & 0.221 & 878 & 0.488 & 4628 \\
\hline HEO Intake (pCi) of ${ }^{137} \mathrm{Cs}$ & 0.071 & 878 & 0.156 & 4628 \\
\hline LAB EDE (rem) for ${ }^{137} \mathrm{Cs}$ & $1.41 \mathrm{E}-8$ & $8.77 \mathrm{E}-5$ & $9.35 \mathrm{E}-8$ & $1.39 \mathrm{E}-3$ \\
\hline HEO EDE (rem) for ${ }^{137} \mathrm{Cs}$ & $4.52 \mathrm{E}-9$ & $8.77 \mathrm{E}-5$ & $9.97 \mathrm{E}-9$ & $4.62 \mathrm{E}-4$ \\
\hline LAB intake (pCi) of ${ }^{137 \mathrm{~m}} \mathrm{Ba}$ & 0.221 & 831 & 0.461 & 4381 \\
\hline HEO intake (pCi) of ${ }^{137 \mathrm{~m}} \mathrm{Ba}$ & 0.0676 & 831 & 0.147 & 4381 \\
\hline LAB EDE (rem) from ${ }^{137 \mathrm{~m}} \mathrm{Ba}$ & $4.75 \mathrm{E}-13$ & $4.24 \mathrm{E}-9$ & $3.11 \mathrm{E}-12$ & $6.7 \mathrm{E}-8$ \\
\hline HEO EDE (rem) from ${ }^{137 \mathrm{~m}} \mathrm{Ba}$ & $1.52 \mathrm{E}-13$ & $4.24 \mathrm{E}-9$ & $3.32 \mathrm{E}-13$ & $2.23 \mathrm{E}-8$ \\
\hline Total LAB Intake (pCi) & 0.442 & 1709 & 0.949 & 9009 \\
\hline Total HEO intake (pCi) & 0.1386 & 1709 & 0.303 & 9009 \\
\hline Total LAB EDE (rem) & $1.41 \mathrm{E}-8$ & $8.77 \mathrm{E}-5$ & $9.35 \mathrm{E}-8$ & $1.39 \mathrm{E}-3$ \\
\hline Total HEO EDE (rem) & $4.52 \mathrm{E}-9$ & $8.77 \mathrm{E}-5$ & $9.97 \mathrm{E}-9$ & $4.62 \mathrm{E}-4$ \\
\hline
\end{tabular}

\footnotetext{
Laborer

${ }^{b}$ Heavy Equipment Operator
} 


\section{ESTIMATING EXPOSURES FROM NONROUTINE EVENTS}

The estimation of exposure incurred from nonroutine events is performed similarly to the method for routine events. Emissions and contaminant air concentrations, if unknown, must be estimated. The resulting concentration is then used to estimate the dose or intake received from the event. These steps are described in this chapter in the following subsections.

The events discussed here are operational events, waste handling events, and external events. Nonroutine operational events include fires and explosions. Waste handling events include situations in which casks or drums develop leaks, spills occur, or other unexpected but preventable events occur. The waste handling events could result in gaseous releases, evaporation from a spill, and/or exposure to solid waste material. The external events discussed are catastrophic occurrences such as earthquakes and aircraft crashes that impact a facility. Exposure routes considered for WM workers involved in nonroutine events resulting in contaminant releases include inhalation of contaminated air and immersion in contaminated air.

The workers evaluated for nonroutine events are those who are immediately involved, such as a forklift operator or waste handler who drops a waste container, and those workers within the vicinity of the occurrence.

\subsection{Emissions From Nonroutine Events}

Many analytical techniques are available for evaluating the impacts from nonroutine events. This document presents methods for conducting a screening-level analysis, which is reasonably conservative, using realistic values associated with release conditions (when available). The estimation of atmospheric emissions resulting from nonroutine events is performed similarly to estimation of emissions from routine events, as explained in chapter 5 . The difference between routine and nonroutine event emission estimation methods are the values used for estimation, such as the event duration (long-term versus short-term), and the size of the event. For routine events, emissions are usually more controlled and predictable, whereas in nonroutine events, emissions are uncontrolled and are usually result in more concentrated air 
concentrations of contaminants. The following subsections describe the types of events that may be evaluated and various assumptions that can be made for each type of event.

\subsubsection{Operational Events}

Operational events evaluated in the PEIS and appropriate for other screening-level analyses include explosions and fires within treatment and storage facilities. For a screening-level analysis, the generic release fractions listed in table 7.1-1 may be used to estimate the amount of contaminant that becomes airborne under various conditions. The chemical and physical properties of the contaminants (e.g., gas, liquid, solid, particle size) should be taken into account. The methods described here were not used for the PEIS but are appropriate alternate methods for estimating exposure due to nonroutine operational events in a screening-level analysis. Methods used in the PEIS to estimate exposure of workers due to nonroutine events are documented elsewhere (ORNL 1995).

Table 7.1-1. Atmospheric Release Fractions for Nonroutine Events

\begin{tabular}{||l|c|}
\hline Type of Release & Release Fraction \\
\hline Gas & 1.0 \\
\hline Simple powder spill & 0.001 \\
\hline Simple liquid spill & 0.0001 \\
\hline Pressurized powder release & 0.01 \\
\hline Pressurized liquid release & 0.05 \\
\hline $\begin{array}{c}\text { Burning of contaminated } \\
\text { combustible solid }\end{array}$ & 0.0005 \\
\hline $\begin{array}{c}\text { Burning of contaminated } \\
\text { combustible liquid } \\
\text { nonvolatile contaminant } \\
\text { volatile contaminant }\end{array}$ & 0.01 \\
\hline
\end{tabular}

Source: MMES 1992; NRC 1988. 
Assumptions for fire-caused contaminant releases may vary among facilities and should be evaluated accordingly. The following assumptions (LANL 1986) are reasonable and may be used at the user's discretion for most facilities when performing screening-level or programmatic analyses:

- Any installed fire protection systems function as designed.

- All systems designed to be critical operate normally throughout the event.

- The fire does not breach the structure.

- The fire is extinguished within two hours.

For outdoor fires, due to the hot temperatures produced, a buoyant plume is expected to result. Even if the fire did not result from a pressurized release, most contaminants would be transported away from the initial release site, depending on the scenario. A ground-level release is assumed, which should be adjusted for thermal plume rise. However, a certain fraction of contaminants (see table 7.1-1), dependent on chemical and physical properties, are assumed to remain within an area surrounding the fire (e.g., $1,000 \mathrm{~m}^{3}$ [1094 $\left.\mathrm{yd}^{3}\right]$ ).

For explosions, it is assumed that the explosion occurs within the facility. In the absence of specific information, simplifying and conservative assumptions may be made. The following assumptions are generally used:

- The maximum airborne concentration of respirable particles within the space into which solid particles or liquid droplets are dispersed by an explosion does not exceed $100 \mathrm{mg} / \mathrm{m}^{3}$ after the first 10 minutes (LANL 1986).

- Engineered safety features may be somewhat affected. Partial HEPA filter failure is assumed, with a remaining efficiency of $99.9 \%$ (LANL 1986).

- In an incinerator explosion, workers inside the facility would be exposed to an air concentration 1,000 times higher than that leaving the facility stack.

- If the contaminant exists in particulate form, it is assumed that if $100 \%$ of the contaminant released is an aerosol, $20 \%$ is respirable (LANL 1986). 


\subsubsection{Waste Handling Events}

The handling event scenarios consist of dropping drums or other containers onto ground surfaces, which releases the contents, or puncturing containers with a forklift in storage or staging areas. The amount released and the consequences that result are based on the drum contents, operating facility systems, and worker configurations relative to the released material.

For an indoor gaseous release from a drum or other container, the following assumptions may be used at the user's discretion in a screening-level analysis to estimate the consequences:

- The event occurs within a facility.

- The entire contents of the container are released (release fraction 1.0 as shown in table 7.1-1) in a short period of time.

- The probability of a pressurized release occurring is dependent on the scenario provided.

- Engineered safety features, which include the ventilation system, are fully functioning.

The exposure duration is determined by estimating the time it requires a worker to walk out of the gas cloud. It is assumed that the individual is $1 \mathrm{~m}$ (1.1 yd) from the spill and immediately leaves the area at a rate of $1 \mathrm{~m} / \mathrm{s}$ (MMES 1992). If this time is less than one minute, then one minute may be used for a more conservative estimate.

For evaporation from a spill, some fraction of the components of the liquid can become airborne as vapors and/or aerosols. Air concentration estimation methods for spills are discussed in section 7.2.

Solid waste materials involved in handling accidents consist of contaminated metal, glass, plastic, wood, cloth, and paper that has been used in facilities where radionuclides or chemicals are present. For radionuclides, it may be assumed that only $1 \%$ of the waste consists of powders in the form of particulates less than $10 \mu \mathrm{m}$ in diameter (MMES 1992). Other assumptions that may be made for this type of consequence are summarized as follows (MMES 1992):

- Twenty-five percent of the contents in the drum are released. Of the material released from the drum, only $1 \%$ is within the respirable range and becomes airborne. 
- It is not credible that the release from a simple spill would be distributed throughout the volume of a facility; therefore, it may be assumed that the material is distributed within a hemispherical volume of a limited size surrounding the drum or container.

- To estimate the exposure duration of the worker, it is assumed that a person is $1 \mathrm{~m}$ (1.1 yd) from the spill and immediately leaves the area. This person, unharmed, leaves the area at a rate of $1 \mathrm{~m} / \mathrm{s}$. Other velocities may be assumed depending on the scenario.

- Once the person leaves the volume, no further exposure occurs.

For outdoor handling accidents that are visibly detectable, such as spills accompanied by fire or explosion, a five minute exposure duration is assumed. For spills that would not necessarily be readily detected visually, a 10 minute exposure duration is assumed.

Outdoor air concentrations resulting from waste handling events may be estimated using models specifically developed for close-in atmospheric dispersion (Bloom 1993). The following assumptions may be used when estimating outdoor air concentrations:

- The worker is standing downwind of the release.

- The release height is zero or at ground level.

- The receptor height is $1.5 \mathrm{~m}$ (1.6 yd).

- The radius of the source is $1.5 \mathrm{~m}$ (1.6 yd).

- No further exposure occurs after the worker leaves the area.

Receptor distances may be varied, and air concentrations may be subsequently estimated at $1 \mathrm{~m}$ (1.1 yd) intervals from $1(1.1 \mathrm{yd})$ to $25 \mathrm{~m}$ (27 yd). An average of these concentrations may be used as an air concentration estimate. 


\subsubsection{EXTERNAL Events}

SARs prepared for specific facilities take into account consequences that can result from credible natural, catastrophic phenomena. For the PEIS, an earthquake is the natural phenomenon considered. Other external events include an aircraft hitting the storage or treatment facility.

Natural phenomena may be capable of acting as initiators of major accidents at nuclear facilities (LANL 1986). These events should be evaluated for the capability of disrupting the confinement system and triggering other failures and for contributing to contaminant dispersal beyond the facility. Assumptions regarding the amount of material that is released should be consistent with amounts released by other events causing damage to the confinement system during operational events (LANL 1986).

Events triggered by an earthquake are assumed to be fires and explosions. The facilities evaluated are involved in incineration and composite waste storage and staging. It is assumed that the confinement system is breached and the engineered safety features are inoperable. Maximum air concentrations can be estimated if it is assumed that the resulting fire is indoors and the ventilation system is not functioning. The risk of release of radioactive and hazardous materials caused by an aircraft crashing into a facility increases with proximity to an airport (LANL 1986). Assumptions regarding the amount of material that is released should be consistent with the amount released by other events causing damage to the confinement system, such as natural phenomena and operational events (LANL 1986). In particular, the crash is assumed to result in fires and explosions.

The following assumptions may accompany the screening-level analysis of external events:

- Treatment facility events result in releases into the operating gallery where workers are located. An exposure duration of one minute is assumed to allow workers to avoid any obstructions and to leave the scene. Half the operating gallery is assumed to fill with contaminated air.

- For storage events involving external initiators, fires, and explosions, the release is assumed to cause a storage cell or bay in the storage facility to fill with contaminated air.

- No ventilation is assumed when assessing impacts to workers from treatment or storage nonroutine events. 
- It is assumed that workers are not blocked, injured from falling or burning debris, or overcome by heat or smoke to such an extent that their escape is impaired. Resulting risks are based only on exposure to contaminants.

\subsection{Estimating Air Concentrations From Nonroutine Events}

Estimation of air concentrations for nonroutine events is performed similarly to the methods described in chapter 5 for routine events. For liquid spills, some fraction of the components of the liquid can become airborne as vapors and/or aerosols. The maximum air concentration from a gas that comes from an evaporating liquid can be estimated from the partial pressure of the component as follows (MMES 1992):

$$
C_{E i}=M_{i} * \frac{P_{i}}{(R * T)}
$$

where $\mathrm{C}_{\mathrm{Ei}}=$ maximum air concentration of component $I$ as a vapor $\left(\mathrm{g} / \mathrm{m}^{3}\right)$,

$\mathrm{P}_{\mathrm{i}} \quad=$ partial pressure of component $I(\mathrm{mmHg})$,

$\mathrm{M}_{\mathrm{i}} \quad$ = molecular weight of component $I(\mathrm{~g} / \mathrm{mole})$,

$R$ = ideal gas constant $\left(0.062363 \mathrm{~m}^{3}-\mathrm{mmHg} / \mathrm{K}\right.$-mole $)$,

$\mathrm{T}=$ absolute temperature (K).

The amount that can become airborne as aerosols can be estimated from a spill release fraction $(0.0001)$ and the amount in the liquid as follows (MMES 1992):

$$
Q_{A, i}=0.0001 * V_{1} * d_{1} * w_{i}
$$

where $Q_{A, j}=$ amount of component $I$ that becomes airborne as an aerosol $(\mathrm{g})$,

$$
\mathrm{V} \quad \mathrm{e}_{1}
$$

liquid volume $\left(\mathrm{cm}^{3}\right)$,

$d_{1}=$ density of the liquid $\left(\mathrm{g} / \mathrm{cm}^{3}\right)$,

$\mathbf{w}_{\mathrm{i}}=$ weight fraction of the component in the liquid (dimensionless). 
Indoor air concentrations are estimated by using a room model as described in section 5.1.2.2.2. For waste handling events, the mixing volume is assumed to be a hemispherical volume, based upon a reasonable size for the scenario. If the assumed mixing volume is enclosed by a hemisphere, the following equation can be used to determine the volume:

$$
V=\frac{2}{3} \pi r^{3}
$$

where $\quad \begin{aligned} \mathrm{V} & =\text { mixing volume }\left(\mathrm{m}^{3}\right) \\ \mathbf{r} & =\text { radius of hemisphere }(\mathrm{m}) .\end{aligned}$

For estimating air concentrations resulting from releases during nonroutine outdoor handling and storage activities, an atmospheric dispersion model for receptors in close proximity to the release may be used. One such code is the INEXPLC code for close-in atmospheric dispersion, explosive releases, and particle deposition (Bloom 1993).

\subsection{Dose Estimation For Nonroutine Events}

Once air concentrations have been estimated, doses and intakes are estimated by the same method as for routine operations (i.e., by multiplying the intake or dose by the appropriate toxicity value). For immersion in a contaminated plume, however, dose estimation is slightly different.

Air concentrations of radionuclides can be used to estimate external doses due to immersion in a contaminated plume using dose coefficients for submersion (EPA 1993). To calculate a dose received from immersion, the following equation can be used:

$$
E D E=A C * D E C * E D
$$

where $\mathrm{EDE}=$ effective dose equivalent (mrem),

$\mathrm{AC}=$ actual or estimated air concentration $\left(\mu \mathrm{Ci} / \mathrm{cm}^{3}\right)$, 
DEC = radionuclide-specific effective dose equivalent coefficient for immersion (mrem/yr per $\mu \mathrm{Ci} / \mathrm{cm}^{3}$ ),

ED = exposure duration (fraction of $\mathrm{yr}$ ).

For short-term exposures to chemicals, the contaminant air concentration is compared to short term exposure levels (STELs) and IDLHs. For radionuclides, the contaminant air concentration is compared to doses as defined in 10 CFR 835, Subpart $\mathrm{N}$. 


\section{RISK CHARACTERIZATION: EXPOSURE}

Estimation of exposure-related risks requires the integration of doses, intakes, and toxicity information into qualitative and quantitative expressions of risk. This integration process is called risk characterization. Along with the risk results gleaned from risk characterization, the process requires interpretive and qualifying information that summarizes the uncertainties and assumptions used to calculate toxicity and exposure. The following sections describe the risk characterization methodology used to characterize health effects caused by carcinogens and noncarcinogens.

After estimating doses and intakes, toxicity values must be derived before risk can be estimated. The purpose of obtaining toxicity values is to evaluate the potential for contaminants to cause adverse health effects in exposed individuals or populations. This evaluation provides an estimate of the relationship between the intake or dose of a contaminant and the increased likelihood and/or severity of adverse effects (EPA 1989a). The nature and strength of the dose-response relationship must be characterized, the doseresponse relationship must be quantitatively evaluated, and, based on this relationship, toxicity values for carcinogens and noncarcinogens are derived.

Based on the dose estimates and toxicity values, separate endpoints of risk are calculated for noncarcinogens and carcinogens. For noncarcinogens, the adverse health effect is expressed as a hazard quotient $(\mathrm{HQ})$ and exposure ratio $\left(E R_{\mathrm{w}}\right)$. For carcinogens, the adverse health effect is expressed as the probability of an individual developing or dying from cancer over his/her lifetime. A summary measure for the combined types of contaminants is not feasible because of the differences in methodologies for calculating these separate indices. Therefore, risk characterization is performed separately for noncarcinogens and carcinogens, and the adverse health effects are expressed separately for the two types of contaminants. 


\subsection{Quantification Of Noncarcinogenic Risk}

Noncarcinogenic effects resulting from exposure to chemicals are evaluated based on the RfD toxicity value. The $\mathrm{RfD}$ (with uncertainties spanning an order of magnitude or greater) is the amount of contaminant taken into the body (in units of $\mathrm{mg}$ of contaminant $/ \mathrm{kg}$ body weight/day) that is not expected to result in adverse health effects. RfDs are developed based on experimental thresholds or experimental No Observed Adverse Effect Levels (NOAELs). The NOAEL concept implies that an intake threshold exists that must be reached before adverse effects occur.

Various types of RfDs may be used, depending on the length of exposure, exposure route, and critical effect being evaluated. The period of exposure to a contaminant can be subchronic, chronic, or acute. Subchronic RfDs are developed for short-term exposures (i.e., between 2 wks and 7 yrs). Chronic RfDs are developed for long-term exposures (i.e., between $7 \mathrm{yrs}$ and a lifetime of $70 \mathrm{yr}$ ).

Ingestion exposure routes usually have documented RfDs, while inhalation routes may report toxicity values as RfCs. An RfC can be converted to an $\mathrm{RfD}$ using the following equation:

$$
R f D=\frac{R f C \times 20}{70}
$$

$$
\begin{aligned}
& \text { where } \mathrm{RfD}=\text { reference dose, } \\
& \text { RfC = reference concentration, } \\
& 20=\text { inhalation rate }\left(\mathrm{m}^{3} / \mathrm{d}\right) \text {, } \\
& 70=\text { body mass }(\mathrm{kg}) \text {. }
\end{aligned}
$$

Subchronic RfDs are used for workers involved in remediation since the duration of remediation activities is usually within the subchronic range. WM workers may be exposed to noncarcinogenic contaminants during operations that exceed the subchronic RfD criteria. In such cases, chronic RfDs are used. Because RfDs are derived for the general public (e.g., sensitive subpopulations), these values may be overly conservative for workers in most cases, with the exception of reproductive hazards. 
Adverse human health effects associated with exposure to noncarcinogens or carcinogenic substances that exhibit noncarcinogenic effects are estimated by comparing the exposure level over a period of time with an RfD derived for a similar exposure period. This HQ ratio is calculated as follows:

$$
H Q=\frac{I}{R f D}
$$

where HQ = hazard quotient (unitless),

I = intake (mg/kg-d),

$\mathrm{RfD}=$ reference dose $(\mathrm{mg} / \mathrm{kg}-\mathrm{d})$.

The intake, $I$, and $\mathrm{RfD}$ are expressed in the same units and represent the same exposure period. Subchronic RfDs are used for exposure periods of 2 wks to 7 yrs or less, while chronic RfDs are used for exposure periods greater than $7 \mathrm{yrs}$. If the hazard quotient is less than or equal to unity (1), the exposure is unlikely to produce adverse threshold toxic effects. The HQ is an indicator that adverse health effects may occur and is not a statistical probability.

If the HQ exceeds unity (1), the actual or estimated air concentration is compared to occupational limits (i.e., first the TLV, then the REL, in the preferred order). This comparison should indicate whether the workers are exposed to air concentrations that exceed regulatory or other occupational limits. These concentration limits are used in the assumption that for routine operations worker exposures do not generally exceed these limits. If exposures exceed these regulatory limits, a more detailed exposure analysis may be warranted, PPE may be required, and engineering modifications may be necessary. To compare the actual or estimated air concentrations to occupational limits, an exposure ratio $\left(E_{w}\right)$ has been derived as shown below. If the $\mathrm{ER}_{\mathrm{w}}$ is greater than unity (1), a potential over-exposure is indicated.

$$
E R_{w}=\frac{C_{A}}{O E L}
$$

where $\mathrm{ER}_{\mathrm{w}}=$ Exposure Ratio,

$\mathrm{C}_{\mathrm{A}} \quad=$ ambient air concentration $\left(\mathrm{mg} / \mathrm{m}^{3}\right)$ adjusted for 8- $\mathrm{hr}$ exposure,

OEL $=$ chosen occupational exposure limit value $(T L V$ or $R E L)\left(\mathrm{mg} / \mathrm{m}^{3}\right)$. 


\subsection{Quantification Of Carcinogenic Chemical and Radionuclide Risk}

Potential carcinogenic effects from chemicals are evaluated using chemical-specific cancer potency factors. Cancer potency factors represent an upper-bound estimate of the probability of a response per unit intake of a chemical over a lifetime (EPA 1992b). Cancer potency factors for chemicals are used to estimate an upper-bound lifetime probability of an individual developing cancer as a result of exposure to a potential carcinogen. This probability represents "cancer incidence" and includes the development of both fatal and nonfatal cancer. Although EPA cancer potency factors do exist for radionuclides, ICRP risk factors are more commonly used by health physicists and are used in this methodology to estimate risks from exposure to radionuclides.

Toxicity values for carcinogenic effects also can be expressed in terms of risk per unit concentration of the substance in the medium where human contact occurs. These measures, called unit risks, are calculated by dividing the cancer potency factor by $70 \mathrm{~kg}(154 \mathrm{lb})$ and multiplying by the inhalation rate (EPA 1989a). These values, published in IRIS and HEAST, have standardized a duration assumption of continuous lifetime exposure. For the worker risk assessment, cancer potency factors are used instead of these unit risks.

Carcinogenic effects resulting from exposure to radionuclides and chemical carcinogens are assumed to have no threshold dose below which health effects are not observed (i.e., any exposure to carcinogens is associated with some degree of risk). According to EPA (1989a), cancer risk may be used as the sole basis for assessing the radiation related human health risks of a site containing radionuclides. Carcinogenic effects usually occur at levels significantly lower than those levels associated with systemic toxic effects; thus, cancer risk is usually the predominant adverse effect of radionuclides. In addition to cancer risks, this methodology uses adverse genetic effects as an endpoint for radionuclides, based on ICRP 60 (ICRP 1990) criteria.

In conjunction with the cancer potency factors used to evaluate chemical carcinogenic effects, EPA assigns a carcinogenic weight-of-evidence classification to each substance based on the strength of human and animal evidence of carcinogenicity. These classifications determine the likelihood that a given contaminant is a carcinogen and are used in the toxicity assessment as a qualitative indicator of a contaminant's toxicity. All radionuclides are classified by EPA as Group A since, at sufficiently high doses, radiation acts as a 
"complete carcinogen" in that it can both induce and promote cancer. The weights-of-evidence are listed below.

Human Carcinogen (Group A):

Probable Human Carcinogen (Group B):

Possible Human Carcinogen (Group C):

Not Classifiable as to Human Carcinogenicity (Group D):

Evidence of Noncarcinogenicity in Humans (Group E):
Sufficient evidence of carcinogenicity in humans

B1-Limited evidence of carcinogenicity in humans; B2-Sufficient evidence of carcinogenicity in animals with inadequate or lack of evidence in humans

Limited evidence of carcinogenicity in animals and Inadequate or lack of human data

Inadequate or no evidence

In accordance with EPA policy, the latest available cancer potency factors should be used to calculate worker risks using this or any other methodology.

Determination of cancer risk due to exposure to a carcinogen consists of two basic steps. First, the estimated air concentration (for a given exposure duration) is compared to the appropriate exposure criteria (e.g., time-weighted average (TWA)-TLV, TLV-STEL, IDLH) based on similar exposure durations. The ratio of this comparison is called is Exposure Ratio (ER acute), and the exposure criteria used in this ratio must be documented. The second step entails the use of the cancer risk methodology as described in RAGS (EPA 1989a), adapted to account for short-term exposures. To adapt this methodology for an increased lifetime cancer risk to short-term exposures, it is assumed that the health effects are dependent on the dose received. That is, the total quantity of a carcinogen inhaled (ingested) during a lifetime is equal to the total quantity of the carcinogen inhaled (ingested) during a short-term exposure for a specific risk.

For chemical carcinogens, risks are estimated as the likelihood of an individual developing cancer over a lifetime as a result of exposure to a potential carcinogen (i.e., incremental or excess individual lifetime cancer risk). The cancer potency factor converts daily intakes averaged over a lifetime of exposure, as derived from the exposure assessment, to the estimated incremental lifetime risk of an individual developing cancer. Generally, the dose-response relationship can be assumed to be linear in the low-dose portion of the multi-stage model dose-response curve. Linear, low-dose cancer risk is estimated by the following equation:

$$
R i s k=I * C P F,
$$


where Risk $=$ probability of an individual developing cancer,

I = daily intake averaged over $70 \mathrm{yrs}$ (mg/kg-day),

$\mathrm{CPF}=$ cancer potency factor $(\mathrm{mg} / \mathrm{kg}-\text { day })^{-1}$.

For workers involved in nonroutine events, a two-tiered approach is used to evaluate short-term exposure to carcinogens. The first tier uses the RAGS methodology for estimating carcinogenic risks (EPA 1989a). However, even if there is a single exposure, this exposure is averaged over the lifetime of the individual. The second tier compares the estimated air concentration to the applicable worker exposure limits (e.g., TWA-TLV, TLV-STEL, and TLV-ceiling) based on the assumed exposure duration and available information. In reporting the results of the consequence analysis, it is important to report the risk and the variation of the estimated air concentration to the allowable worker exposure concentration limits.

Risk is usually expressed using one significant figure (e.g., 2E7) because risk estimates are not perceived to be absolute representations of risk. Individual risks are interpreted as the probability of an individual developing cancer over his/her lifetime as a result of exposure to contaminants originating from a given site or TSD facility. Equation 8.4 is only valid at low risk levels (i.e., below estimated risks of 1E-2). At risks above this level, a standard "one-hit equation" can be used to estimate risks (EPA 1989a). This methodology does not consider this "one-hit equation," however, because it is assumed that 1.0E-6 is the risk level that triggers the need for more detailed evaluation and possible site remediation. Since any risk above 1.0E-6 will be flagged as a concern, it is not necessary, especially in a screening-level analysis, to refine the calculations of risk estimates higher than $1.0 \mathrm{E}-2$.

The endpoints for risk evaluations of radionuclides are cancer fatality (the probability of an individual dying from cancer), cancer incidence, and genetic effects. Although cancer incidence may be the most "sensitive" potential endpoint several types of cancer risks are calculated to ensure a thorough presentation of the potential health effects posed by worker activities at a site or WM facility. Risk managers are then able to apply one or more endpoints of a worker risk assessment to remediation or WM activity decisions. The toxicity factors and their respective endpoints are summarized in table 8.2-1. Based on ICRP 60 (1990), the occupational fatal risk factor for low dose rates over all tissues or organs is 4E-4risk/rem. The occupational cancer incidence risk factor (probability of developing fatal and nonfatal cancers) is 1.4E3risk/rem. The genetic effects risk factor is $6 \mathrm{E}-5$ risk/rem. These risk factors are used in this methodology to estimate cancer fatality and incidence risks and the risk of genetic effects. 
Table 8.2-1. Summary of Health Effect Endpoints

\begin{tabular}{||l|c|c|}
\hline \multicolumn{1}{|c|}{ Type of Contaminant } & Toxicity Factor & Endpoint \\
\hline Noncarcinogen & $\begin{array}{c}\text { RfD } \\
\text { (chronic, subchronic, or } \\
\text { acute) }\end{array}$ & HQ, ER \\
\hline Chemical Carcinogen & Cancer Potency Factor & Cancer Incidence \\
\hline Radionuclide & 1.4E-3risk/rem & Cancer Incidence \\
\hline Radionuclide & 4E-4risk/rem & Cancer Fatality \\
\hline Radionuclide & 6E-5risk/rem & Genetic Effects \\
\hline
\end{tabular}

Source: ICRP 1990.

The nominal probability coefficient for fatal cancers is used to derive the cancer incidence nominal probability coefficient. The probability of fatal cancer, $F$ (which for workers is $80 \%$ of $F$, as described in ICRP 60 ) is divided by the lethality fraction, $k$, for each organ. The total cancers per organ are then summed over all organs to result in total cancer incidence nominal probability coefficient of $1.4 \mathrm{E}-3 / \mathrm{rem}$.

ICRP 60, Table 4.

For radionuclides, risk factors are used to estimate lifetime fatal cancer risk, lifetime cancer incidence risk, or the risk of genetic effects in the following equation:

$$
\text { Risk }=R F * E D E,
$$

where $\mathrm{EDE}=$ effective dose equivalent an individual receives during an exposure period (rem),

$\mathrm{RF}=$ cancer fatality, cancer incidence, or genetic effects risk factor (risk/rem lifetime dose).

Although the risks from exposure to chemicals and radionuclides can be quantified, the models, assumptions, and data used to estimate chemical risks differ from those used to estimate radionuclide risks. One important difference between the two is how the cancer toxicity values (i.e., cancer potency factors and risk factors) were developed. For both radionuclides and chemicals, cancer toxicity values are obtained by extrapolation from experimental and epidemiological data. For radionuclides, human epidemiological data form the basis of the extrapolation, while for many chemical carcinogens, laboratory experiments are the primary basis for the extrapolation. Another even more fundamental difference 
between the two is that cancer potency factors for chemical carcinogens generally represent an upper-bound or $95^{\text {th }}$ percent confidence limit value, while radionuclide risk factors are best estimate values.

\subsubsection{Example Risk Calculation For Carcinogenic Chemical}

The risk calculation described here is an extension of the exposure calculation described in section 5.3. Once the intake via ingestion and inhalation is calculated, the cancer incidence risks from inhalation and ingestion of benzene can be estimated by multiplying the intake by the benzene cancer potency factor $\left(2.9 \mathrm{E}-2 \mathrm{mg} / \mathrm{kg}^{-\mathrm{d}^{-1}}\right)$. The results of the risk characterization of inhalation and ingestion of benzene are shown in table 8.2-2.

Table 8.2-2. Risks from Ingestion and Inhalation of Benzene (example)

\begin{tabular}{|l|c|c|c|c|c|c|}
\hline \multirow{2}{*}{ Activity } & \multicolumn{3}{|c|}{ Inhalation } & \multicolumn{3}{c|}{ Ingestion } \\
\cline { 2 - 7 } & LAB $^{\mathbf{2}}$ & HEO $^{\mathbf{b}}$ & SUP $^{\mathbf{c}}$ & LAB & HEO & SUP \\
\hline Excavation of overburden & $2 \mathrm{E}-11$ & $3 \mathrm{E}-12$ & $3 \mathrm{E}-12$ & $5 \mathrm{E}-13$ & $2 \mathrm{E}-13$ & $2 \mathrm{E}-13$ \\
\hline $\begin{array}{l}\text { Excavation of } \\
\text { contaminated soil }\end{array}$ & $2 \mathrm{E}-7$ & $4 \mathrm{E}-8$ & $4 \mathrm{E}-8$ & $6 \mathrm{E}-9$ & $3 \mathrm{E}-9$ & $3 \mathrm{E}-9$ \\
\hline Backfill and compaction & $2 \mathrm{E}-11$ & $3 \mathrm{E}-12$ & $3 \mathrm{E}-12$ & $4 \mathrm{E}-13$ & $2 \mathrm{E}-13$ & $2 \mathrm{E}-13$ \\
\hline Package contaminated soil & $2 \mathrm{E}-8$ & $3 \mathrm{E}-9$ & $3 \mathrm{E}-9$ & $3 \mathrm{E}-11$ & 1E-11 & $1 \mathrm{E}-11$ \\
\hline
\end{tabular}

${ }^{a} \mathrm{LAB}=$ laborer

${ }^{b}$ HEO = heavy equipment operator

${ }^{c}$ SUP $=$ Supervisor

\subsubsection{Example Risk Calculation for Radionuclide}

The risk calculation here is an extension of the exposure calculation described in section 6.3. Individual cancer risks from direct radiation exposure are derived by multiplying the EDE (rem) by the risk factors presented in table 8.2-1 (ICRP 1990). The resulting population risks for each activity are shown in table 8.2-3. These population risks are obtained by calculating the risk to an individual laborer (or heavy equipment operator) in each worker category and multiplying by the number of laborers (or heavy equipment operators) involved in the activity. 
Table 8.2-3. Cancer Risks from ${ }^{137} \mathrm{Cs}$ and ${ }^{137 m} \mathrm{Ba}$ via Direct Radiation

\begin{tabular}{|c|c|c|c|c|c|c|}
\hline \multirow[t]{2}{*}{ Activity } & \multicolumn{3}{|c|}{ LAB Cancer Risk } & \multicolumn{3}{|c|}{ HEO Cancer Risk } \\
\hline & Fatality & Incidence & $\begin{array}{l}\text { Genetic } \\
\text { Effects } \\
\end{array}$ & Fatality & Incidence & $\begin{array}{l}\text { Genetic } \\
\text { Effects }\end{array}$ \\
\hline $\begin{array}{l}\text { Construction of } \\
\text { cutoff wall }\end{array}$ & $1 \mathrm{E}-5$ & $4 \mathrm{E}-5$ & $7 \mathrm{E}-6$ & $4 \mathrm{E}-6$ & $1 \mathrm{E}-5$ & $6 \mathrm{E}-7$ \\
\hline $\begin{array}{l}\text { Construction of } \\
\text { concrete slab }\end{array}$ & $2 E-4$ & $6 \mathrm{E}-4$ & $3 E-4$ & $2 \mathrm{E}-5$ & $7 \mathrm{E}-5$ & $3 E-6$ \\
\hline Rough grade fill & $3 \mathrm{E}-7$ & 10E-7 & $4 \mathrm{E}-8$ & $5 E-8$ & $2 \mathrm{E}-7$ & 8E-9 \\
\hline $\begin{array}{l}\text { Cover region with } \\
\text { clay }\end{array}$ & $4 \mathrm{E}-7$ & 1E-7 & $6 \mathrm{E}-8$ & $7 \mathrm{E}-8$ & $3 \mathrm{E}-7$ & $2 \mathrm{E}-8$ \\
\hline $\begin{array}{l}\text { Cover region with } \\
\text { sand }\end{array}$ & $8 E-10$ & $3 E-9$ & $1 E-10$ & $2 \mathrm{E}-10$ & $7 E-10$ & $3 \mathrm{E}-11$ \\
\hline $\begin{array}{l}\text { Cover with } \\
\text { geomembrane }\end{array}$ & $8 \mathrm{E}-9$ & $3 E-8$ & $1 \mathrm{E}-9$ & 2E-9 & $7 \mathrm{E}-9$ & $3 \mathrm{E}-10$ \\
\hline Cover with geotextile & 2E-11 & $8 \mathrm{E}-11$ & $3 E-12$ & $4 \mathrm{E}-12$ & $1 E-11$ & $6 \mathrm{E}-13$ \\
\hline $\begin{array}{l}\text { Cover region with } \\
\text { topsoil }\end{array}$ & $9 \mathrm{E}-12$ & $3 E-11$ & $1 \mathrm{E}-12$ & $2 \mathrm{E}-12$ & $7 \mathrm{E}-12$ & $3 \mathrm{E}-13$ \\
\hline Seeding and planting & $2 \mathrm{E}-12$ & $8 \mathrm{E}-12$ & $4 \mathrm{E}-13$ & N/A & N/A & N/A \\
\hline
\end{tabular}

LAB = laborer

${ }^{b}$ HEO $=$ heavy equipment operator

Cancer risks from inhalation and ingestion of radionuclides are derived by multiplying the EDE (rem) by a fatality risk factor of $4 \mathrm{E}-4$ risk/rem, an incidence risk factor of $1.4 \mathrm{E}-3$ risk/rem, and a genetic effects risk factor of 6E-5 risk/rem (ICRP 1990). The resulting population risks for each subactivity are shown in table 8.2-4. These population risks are obtained by calculating the risk to an individual laborer (or heavy equipment operator) in each worker category and multiplying by the number of laborers (or heavy equipment operators) involved in the activity. 
Table 8.2-4. Cancer Risks from ${ }^{137} \mathrm{Cs}$ and ${ }^{137 m} \mathrm{Ba}$ via Inhalation and Ingestion Routes

\begin{tabular}{||l|c|c|c|c|c|c|}
\hline \multirow{2}{*}{$\begin{array}{l}\text { Worker Type } \\
\text { and Activity }\end{array}$} & \multicolumn{3}{|c|}{ Inhalation } & \multicolumn{3}{c|}{ Ingestion } \\
\cline { 2 - 7 } & Fancer & $\begin{array}{c}\text { Cancer } \\
\text { Incidence }\end{array}$ & $\begin{array}{c}\text { Genetic } \\
\text { Effects }\end{array}$ & $\begin{array}{c}\text { Cancer } \\
\text { Fatality }\end{array}$ & $\begin{array}{c}\text { Cancer } \\
\text { Incidence }\end{array}$ & $\begin{array}{c}\text { Genetic } \\
\text { Effects }\end{array}$ \\
\hline $\begin{array}{l}\mathrm{LAB}^{2} \text { (cutoff } \\
\text { wall) }\end{array}$ & $6 \mathrm{E}-12$ & $2 \mathrm{E}-11$ & $9 \mathrm{E}-13$ & $4 \mathrm{E}-8$ & $1 \mathrm{E}-7$ & $5 \mathrm{E}-9$ \\
\hline $\begin{array}{l}\text { HEO } \\
\text { wall) }\end{array}$ & $2 \mathrm{E}-12$ & $6 \mathrm{E}-12$ & $3 \mathrm{E}-13$ & $4 \mathrm{E}-8$ & $1 \mathrm{E}-7$ & $5 \mathrm{E}-9$ \\
\hline $\begin{array}{l}\text { LAB (concrete } \\
\text { slab) }\end{array}$ & $4 \mathrm{E}-11$ & $1 \mathrm{E}-10$ & $6 \mathrm{E}-12$ & $6 \mathrm{E}-7$ & $2 \mathrm{E}-6$ & $8 \mathrm{E}-8$ \\
\hline $\begin{array}{l}\text { HEO (concrete } \\
\text { slab) }\end{array}$ & $4 \mathrm{E}-12$ & $1 \mathrm{E}-11$ & $6 \mathrm{E}-13$ & $2 \mathrm{E}-7$ & $7 \mathrm{E}-7$ & $3 \mathrm{E}-8$ \\
\hline
\end{tabular}

LAB = laborer

${ }^{b}$ HEO = heavy equipment operator

\subsection{Data Sources For Toxicity Values}

IRIS, EPA's on-line toxicity value database, and HEAST are the preferred sources for numerical toxicity values and information. IRIS, which is updated quarterly to incorporate new evidences and findings, provides toxicity factors such as chemical-specific cancer potency factors, RfDs, supporting discussion and references (EPA 1988f). The information contained in IRIS has been reviewed and verified by EPA work groups.

HEAST summarizes interim RfDs, cancer potency factors, and other toxicity information. If HEAST does not have the necessary information, EPA criteria documents, which contain general toxicity information, can be consulted. The ATSDR toxicological profiles are the next source of information for toxicity values. Toxicological profiles contain such information as levels of exposure, physicochemical properties, and regulatory and advisory status of contaminants. ATSDR minimum risk levels (MRLs) may also be useful for evaluating short-term exposures.

Before using references other than those cited in IRIS or HEAST, the Environmental Criteria Assessment Office (ECAO) should be contacted. ECAO can provide general toxicological information and guidance 
concerning extrapolations and the evaluation of chemicals without toxicity values. For most purposes and to be consistent with EPA guidance, substances without numerical toxicity values in IRIS or HEAST are usually dropped from the risk assessment analysis and mentioned qualitatively. Eliminating these substances is a source of uncertainty in the risk assessment. For the PEIS, some other methods are used for estimating toxicity values for substances without values in IRIS or HEAST. These methods are described elsewhere (ORNL 1995).

\subsection{Risk Estimates For Multiple Substances}

At most sites, the risk from simultaneous exposure to many hazardous substances must be estimated. The following equation (EPA 1989a) estimates the incremental individual lifetime cancer fatality and cancer incidence risks for simultaneous exposure to several carcinogens. Equation 8.6 does not consider synergism of contaminants. Synergy is a complicated issue that requires a toxicologist's evaluation on a site-specific basis. For a programmatic, screening-level, or installation-level analysis, the level of detail required to evaluate synergy is unwarranted.

Despite the differences between chemical and radiological lifetime cancer risk estimation methods, cumulative risks attributable to multiple contaminants or multiple pathways still must be considered. Radiological cancer fatalities must be reported separately and not summed with cancer incidence.

$$
\operatorname{Risk}_{T}=\sum_{i=1}^{n} \operatorname{Risk}_{i}
$$

where $\quad$ Risk $_{\mathrm{T}}=$ total cancer risk,

Risk $_{i}=$ risk estimate for the $i^{\text {th }}$ substance,

n $\quad$ total number of substances for the pathway.

Health effects resulting from exposure to several noncarçinogens are addressed by a hazard index (HI) approach. The hazard index is equal to the sum of the hazard quotients. If the HI exceeds unity (1), there may be concern for potential health effects. The $\mathrm{HI}$ is derived from the following equation: 


$$
H I=\sum_{i=1}^{n} \frac{I_{i}}{R f D_{i}}
$$

where HI = hazard index (unitless)

$I_{i} \quad=$ daily intake for the $i^{\text {th }}$ toxicant $(\mathrm{mg} / \mathrm{kg}-\mathrm{d})$,

$\mathrm{RfD}_{\mathrm{i}}=$ reference dose for the $\mathrm{i}^{\text {th }}$ toxicant $(\mathrm{mg} / \mathrm{kg}-\mathrm{d})$,

n = total number of noncarcinogenic toxicants.

The daily intake, $I_{i}$, and RfD are expressed in the same units and represent the same exposure period. Limitations associated with the hazard index are that (1) hazard quotients are combined for substances with RfDs based on critical effects of various toxicological significance, (2) RfDs of varying levels of confidence might be combined, and (3) combining many compounds that do not produce the same type of effect could overestimate the potential for effects. If a $\mathrm{HI}$ greater than unity (1) results from a risk evaluation, then a chemical-specific evaluation must be conducted to determine whether hazards from multiple noncarcinogenic substances are a concern. The exposure ratio $\left(E R_{w}\right)$ can also be summed in the same fashion as the HQ (see equation below). If the exposure index (EI) is greater than one, then adverse health effects are considered likely to occur.

$$
E I=\sum_{i=1}^{n} \frac{I_{i}}{O E L_{i}}
$$

where $\mathrm{EI}=$ exposure index (unitless),

I = daily intake for the $\mathrm{i}^{\text {th }}$ toxicant (mg/kg-d),

OEL = occupational exposure limit for the $\mathrm{i}^{\text {th }}$ (TLV, TWA-TLV, or REL) $\left(\mathrm{mg} / \mathrm{m}^{3}\right)$,

$\mathrm{n} \quad=$ total number toxicants.

\subsection{Combining Risks Across Exposure Pathways}

The total exposure of an individual or population to various chemicals equals the sum of the exposures by all pathways. For each pathway, the risk estimates and hazard indices have been developed for a particular 
exposure area or exposure point and time period; they do not necessarily apply to other locations or time periods. Risks from two pathways are not summed unless the same individual (or population) is predicted to be exposed via both pathways at the same exposure point (or area) within the same time period. If it is considered appropriate to sum risks across pathways, cancer risks for each exposure pathway contributing to exposure of the same individual or population should be added, as follows, in a given time period:

Total Cancer Risk $=\operatorname{Risk}\left(E P_{1}\right)+\operatorname{Risk}\left(E P_{2}\right)+\ldots+\operatorname{Risk}\left(E P_{n}\right)$,

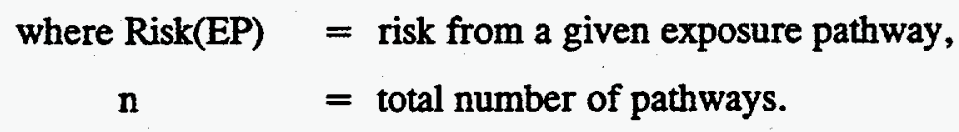

Although the methods differ for estimating cancer potency for radionuclides and chemicals, carcinogenic chemical and radiological cancer incidence risks are often summed in the Superfund arena. For this screening-level methodology, cancer incidence for radionuclides and carcinogenic chemicals are summed; however, radiological fatalities must be reported separately.

Noncarcinogenic effects from several exposure pathways can be estimated by separately calculating the total HI for each exposure duration (i.e., chronic, subchronic, and acute). The HIs for all exposure pathways are ranked and the maximum $\mathrm{HI}$ is reported as the effect on an individual or population to various noncarcinogenic chemicals.

\subsection{Expressions Of "Risk"}

Noncarcinogenic health effects and carcinogenic risks are not combined because their derivations are incompatible and they are based on different toxicity factors (cancer potency factors and RfDs).

Carcinogenic and noncarcinogenic worker risks are calculated independently for each exposure medium and pathway. The doses and associated risks are usually estimated for an individual; however, population risk can also be calculated by weighting the individual risk of a worker population by the number of workers exposed. For example, if there are five laborers working at the same location from the release 
site or TSD facility, with the same job duration and frequency, the dose and associated risk attributed to one worker is multiplied by the number of workers to yield a worker population risk. For radiological doses, population doses have units of person-rem.

Population health effects from exposure to carcinogens are interpreted as the number of cancer incidences, cancer fatalities, and genetic effects in a population as a result of exposure to contaminants.

For noncarcinogens, health effects are expressed in terms of maximum individual hazard indices. An indicator for noncarcinogenic effects for a population does not exist.

\subsection{Uncertainties In Risk Assessment}

Uncertainties in the risk assessment are documented along with the final risk estimates to ensure that results are placed in proper perspective. Uncertainties associated with each element or task of the risk assessment are also evaluated and documented to identify additional data collection needs and to determine which uncertainties contribute significantly to the overall uncertainty of the assessment. Sources of uncertainty in risk assessment include the following:

- Source terms and waste characterization,

- Definition of the physical setting,

- Model applicability and assumptions,

- Exposure parameters,

- Toxicity and risk characterization (EPA 1989a).

For each application of the methodology, these uncertainties should be documented on a site-specific basis. Defining the physical setting often requires judgements and assumptions. Within the definition of the physical setting, uncertainties about current and future land uses, potential current and future exposure pathways, and contaminants of concern are identified. The sources and quality of land use information, including the likelihood of occurrence for future land uses and exposure pathways, are described. A rationale for including or excluding each exposure pathway in the risk assessment is documented by a conceptual model. Also, the reasons for and possible consequences of excluding a contaminant from the assessment are reported with the final risk estimates. 
For WM analyses such as those used in the PEIS, assumptions are made about operating future TSD facilities that are not yet built. Estimating risks for facilities that do not yet exist involves making assumptions about facility design, worker locations, shielding, future waste concentrations, and exposure scenarios. These simplifying assumptions are a large source of uncertainty.

The applicability of the models used in risk calculation and their mathematical formulations are also evaluated for uncertainties. The models are evaluated for their ability to approximate relationships among site-specific environmental conditions. Key assumptions used in the models are documented along with a discussion of their potential impacts on final risk estimates. The potential impacts of each assumption on risk estimates are reported in terms of direction (i.e. overestimated or underestimated risk) and magnitude (e.g., order of magnitude).

Uncertainties may also occur in exposure parameter values. These uncertainties should be discussed, and a rationale for their selection should be provided. In addition, the potential magnitude and direction of bias (i.e., overestimation or underestimation of risk) resulting from assumptions and parameter values should be discussed.

Toxicity assessment uncertainties include potential for human toxicity, potential interactions from multiple chemicals, and derivation of toxicity (e.g., human or animal data, duration of study, and any special considerations). If a contaminant is excluded from the risk assessment due to inadequate toxicity information, the contaminant's potential health effects and possible consequences of its exclusion should be documented. 


\section{RISK CHARACTERIZATION: SAFETY RISKS}

During cleanup of DOE facilities and performance of TSD activities, workers face safety risks from construction and other activities in addition to the risks and hazards posed by exposure to harmful substances. The primary safety risks that workers confront are injuries and fatalities from general construction accidents, injuries/illnesses and fatalities from operational accidents, and illnesses and fatalities from heat stress. Construction is a general term that covers activities such as electrical work, masonry, stonework and plastering, roofing, road construction, plumbing, painting, and carpentry in addition to building activities (OSHA 1990). Operational activities include tasks that are performed during the routine operation of WM TSD facilities, as opposed to the construction of those facilities. This section describes the effect of these hazards on worker health, fatality rate data, injury rate data, and the integration of safety risks into the risk evaluation. Estimation of safety risks is an important component of the overall worker risk evaluation since fatal risks associated with physical hazards often overshadow estimated exposurerelated risks.

Fatality risks are described in terms of fatalities per activity (e.g., construction, heat stress, operation) per person-hour. Risks of sustaining illnesses and injuries are described in terms of Total Recordable Cases (TRC). TRCs include all work-related deaths and illnesses and those work-related injuries that result in loss of consciousness, restriction of work or motion, transfer to another job, or require medical treatment beyond first aid (DOE 1992).

\subsection{Construction-related Accidents}

Construction-related accidents include injuries and fatalities that may occur during remedial or TSD work.

These conditions are discussed in the following sections. 


\subsubsection{Construction Fatalities}

According to the U.S. Department of Labor (DOL) (1990), the largest number of fatalities throughout all industries or within the construction group for 1985-1989 occurs in Standard Industrial Classification (SIC) group 162, Heavy Construction. The fatalities for this activity represent $25 \%$ of the total fatalities for the five-year period. Ninety percent of the construction-related accidents are attributable to the following four causes (OSHA 1990):

- Falling from an elevation (33\%),

- Being struck by a machine or material $(22 \%)$,

- Entrapment (18\%),

- Receiving an electrical shock (17\%).

Fatalities due to falls occur most frequently among special trade contractors, whereas entrapment fatalities occur most frequently in heavy construction. Approximately $75 \%$ of fatalities caused by being struck by machines involve primarily heavy construction equipment such as trucks, cranes, graders, and scrapers (OSHA 1990). For fatalities due to trench cave-ins, $75 \%$ of the trenching fatalities occur in trenches less than $15 \mathrm{ft}$ in depth. Of the total fatalities due to electric shock, $95 \%$ were due to contact with live parts and $5 \%$ were due to ungrounded tools. The percentage of fatalities due to electrical shock is almost the same for heavy construction and electrical work. This, in part, is the result of workers coming into contact with overhead wires.

Commonly cited estimates of occupational fatalities vary significantly in terms of what types of accidents are considered in estimating fatalities, the population covered, data sources, and methods (NSC 1991). The construction fatality rates according to organization are listed in table 9.1-1. 
Table 9.1-1. Construction Fatality Rates

\begin{tabular}{||l|c|c|c|}
\hline \multicolumn{1}{|c|}{ Organization } & $\begin{array}{c}\text { Number } \\
\text { of } \\
\text { Fatalities }\end{array}$ & $\begin{array}{c}\text { Fatality Rates } \\
\text { (Fatalities per } \\
100,000 \text { full-time } \\
\text { workers) }\end{array}$ & $\begin{array}{c}\text { Fatalities/ } \\
\text { person-hr }\end{array}$ \\
\hline $\begin{array}{l}\text { National Safety Council } \\
(1990)\end{array}$ & 2100 & 33 & $1.65 \mathrm{E}-7$ \\
\hline $\begin{array}{l}\text { Bureau of Labor Statistics } \\
(1988)\end{array}$ & 850 & 24.5 & $1.2 \mathrm{E}-7$ \\
1989 & 780 & 22.4 & $1.1 \mathrm{E}-7$ \\
\hline
\end{tabular}

Sources: NSC 1991; BLS 1990.

\subsubsection{CONSTRUCTION INJURIES}

The Bureau of Labor Statistics, National Safety Council (NSC), and DOE maintain records of work-related personnel illnesses, injuries, and fatalities. The incidence rates attributed to the construction industry are summarized in table 9.1-2. The Bureau of Labor Statistics (BLS) statistics are not comparable to the NSC incidence rates since the BLS excludes public employees (among other worker groups). The DOE construction contractors are categorized into two groups, cost construction contractors and lump construction contractors. Some of the contractors listed in cost construction contractors are associated with restoration-related activities. As shown, the risks/person-hr are less for DOE-related activities than for commercial activities. 
Table 9.1-2. Construction Injury Rates

\begin{tabular}{||c|c|c|}
\hline Source & Total Recordable Cases & Risk/person-hr \\
\hline Bureau of Labor $1989^{\circ}$ & 14.3 & $7.2 \mathrm{E}-5$ \\
\hline National Safety Council 1990 & 9.1 & $4.6 \mathrm{E}-5$ \\
\hline $\begin{array}{c}\text { DOE (average 1986-1990) } \\
\text { Construction Contractors: } \\
\text { Cost Construction } \\
\text { Lump Construction }\end{array}$ & & \\
\hline
\end{tabular}

- Total Recordable Cases; Incidence Rate is the number of injuries, illnesses, or lost work days per 100 full-time employees, 200,000 work-hrs (100 person-yrs).

Source: NSC 1991.

- Source: DOE 1992.

\subsection{Operational Fatalities And Injuries}

Operational occurrences (i.e., fatalities and injuries/illnesses) are estimated for WM workers performing waste handling and treating activities during the operation of TSD facilities. Operational occurrences are similar to the nonroutine events that could occur during construction activities; however, because operational events occur during a different phase of the activity, they are treated separately and have different fatality and injury rates than construction activities.

Operational fatality and injury/illness rates were determined using the SIC group 495, Sanitary Services. This group was chosen because it includes 4952 , sewerage systems, and 4953, refuse systems, which cover personnel involved in the operation of waste treatment plants and landfills (DOE 1992). The risk factors used to estimate fatalities and injuries/illnesses incurred during the operation of WM TSD facilities are listed in table 9.2-1. These operational fatality and injury rates are also applicable to ER workers involved in waste treatment operations that are similar to "typical" WM operational activities. 
Table 9.2-1. Operational Event Risk Factors

\begin{tabular}{|c|c|}
\hline Operational Fatalities & $\begin{array}{c}\text { Operational } \\
\text { Injuries/minesses }\end{array}$ \\
\hline $9.0 \mathrm{E}-8 / \mathrm{person}-\mathrm{hr}$ & $7.65 \mathrm{E}-5 /$ person-hr \\
\hline
\end{tabular}

${ }^{2}$ BLS 1993; Knestaut, A. and J. Stinson, U. S. Bureau of Labor Statistics, personal communication with Janice Legg, ORNL, November 23, 1993.

${ }^{b}$ BLS 1992.

\subsection{Heat Stress}

Heat-induced occupational injuries and reduced productivity occur in situations where the total heat load (environmental and metabolic) exceeds the capacity of the body to maintain normal body function without excessive strain (NIOSH 1986). Environmental factors associated with heat stress are ambient temperature, ambient vapor pressure, air motion, and mean radiation temperatures. Other factors include metabolic heat production and clothing. Human factors associated with heat stress are physical condition, level of acclimatization, degree of hydration, age, and gender.

Heat-related disorders can be a potentially serious problem for remedial workers. ER work involves high levels of physical exertion, outdoor exposures to high ambient temperatures, humidity, and solar radiation and requires the use of protective clothing. The adverse impact of these factors on a worker can result in a high risk of heat stress. Personal protective clothing is a major risk factor because it prevents evaporative heat loss to the environment (Favata 1990).

\subsubsection{Heat Stress IllNesSes}

Assessment of heat stress may be conducted by measuring the climatic and physical factors of the environment and then evaluating their effects on the human body by using an appropriate heat-stress index. Physiologic responses to an increasing heat load include an increase in heart rate, body temperature, skin 
temperature, and sweat production. In a specific situation, one or all of these responses may be observed. The magnitude of the responses will, in general, reflect the total heat load.

Estimation of the incidence of occupational heat-related illnesses in the United States is uncertain (NIOSH 1992). Employers are required to maintain records concerning occupational illness and injuries and submitted to OSHA (OSHA $200 \mathrm{log}$ ). From this information, the BLS estimates illness and injury rates. Heat-related disorders are recorded as a disorder due to a physical agent. The BLS physical agent incident rates do not differentiate the type of physical agent, nor is it possible to obtain information specific to heat stress illness rates from BLS. However, the BLS provides a physical agent disorder rate according to occupational category. If it is assumed that all physical agent disorders are heat-related disorders, a heat stress risk factor of 9.5E-8 risk/person-hr can be estimated. This assumption probably results in an overestimate of heat stress and is more applicable to commercial activities.

The DOE maintains a database, the Safety Performance Measurement System (SPMS), in which occupational health statistics are compiled. This database contains a record of heat-related disorders that occurred throughout the DOE complex. These data can be used to estimated the risk of heat-related disorders from the total person-hrs associated with specific DOE activities. The heat-related disorders for cost and lump construction, the activities most closely resembling remediation activities, are used to derive heat-related disorder rates. These results are shown in table 9.3-1.

Table 9.3-1. Heat-Related Disorders within DOE, 1991 and 1992

\begin{tabular}{|c|c|c|c|}
\hline Year Evaluated & \# Cases & Total Person-hr & $\begin{array}{c}\text { Heat-related } \\
\text { Ilnesses/person-hr }\end{array}$ \\
\hline 1991 & 10 & $30,208,100$ & $3.3 \times 10^{-7}$ \\
1992 & 6 & $30,667,900$ & $1.96 \times 10^{-7}$ \\
1991 and 1992 & 16 & $60,876,000$ & $2.7 \times 10^{-7}$ \\
\hline
\end{tabular}

Source: EG\&G 1993b. 
To predict site-specific heat-related disorders, an industrial hygienist can use a number of indices: Wet Bulb Globe Temperature (WBGT), Adjusted temperature $\left(\mathrm{T}_{\mathrm{adj}}\right)$, Effective Temperature (ET), and Wet Globe Temperature (WGT). The most widely used method for estimating occupational heat stress is the WBGT and the $T_{2 \mathrm{dj}}$. The American Conference of Governmental Industrial Hygienists (ACGIH) (ACGIH 1991) uses the WBGT index to calculate the WBGT for outdoors with solar load.

According to NIOSH (1986), in workplaces where vapor and air impermeable encapsulating ensemble must be worn, the WBGT is not the appropriate measurement of environmental heat stress. In these instances, the $T_{2 d j}$ should be used. $T_{2 d j}$ is not a surrogate measure for WBGT but rather is an indication of when to take a physiological measurement of a worker's heat stress (e.g., pulse or body temperature). The $T_{\text {adj }}$ is the ambient dry-bulb temperature adjusted for solar radiation. NIOSH offers guidance on the suggested frequency of physiological monitoring based on adjusted temperature (NIOSH 1985).

\subsubsection{Heat Stress Fatalties}

Fatality rates from two time periods for which data were available are listed in table 9.3-2. The average rate derived from these two time periods is assumed to be representative and is chosen for this methodology. If better information becomes available, the risk factors should be adjusted to reflect such changes. From 1986 through 1991, no heat-related fatalities associated with DOE and its contractors were recorded (SPMS 1993). 
Table 9.3-2. Heat Stress Fatality Rates

\begin{tabular}{|c|c|c|}
\hline Time Period & $\begin{array}{c}\text { Average Fatality Rate } \\
\text { (deaths/100,000 } \\
\text { workers) }\end{array}$ & Fatalities/person-hr' \\
\hline $1952-1955,1966$ & 0.42 & $2.0 \mathrm{E}-9$ \\
\hline $1980-1984$ & 0.22 & $1.0 \mathrm{E}-9$ \\
\hline Average & 0.32 & $1.6 \mathrm{E}-9$ \\
\hline
\end{tabular}

Source: Ellis 1972; Roberts 1987.

Assuming 2000 full-time person-hrs/yr.

\subsection{Compilation Of Safety Risks}

Safety risks from general construction activities, operational activities, and heat stress are separated into estimates for safety risk fatalities and illnesses/injuries. General construction, operational, and heat stress fatalities are estimated by determining total person-hours per activity and multiplying by appropriate fatality rates (tables 9.1-1, 9.2-1 and 9.3-2). At sites where there are no construction-related activities, these risks are not estimated. The number of fatalities due to heat stress are listed if data indicate that PPE would be needed.

General construction and operational injuries and heat stress illnesses are estimated by determining total staff-hours per activity and multiplying by appropriate injury or illness rates (tables 9.1-2, 9.2-1, and 9.3-1). Injuries and illnesses attributed to general construction, facility operation, and heat stress are then summed according to worker category. 


\section{REFERENCES}

Bloom, S. 1993. Models for Close-in Atmospheric Dispersion, Explosive Releases, and Particle Deposition. ORNL/TM-12452. Oak Ridge National Laboratory. Oak Ridge,TN. October 1993.

BLS (U.S. Department of Labor, Bureau of Labor Statistics). 1990. Occupational Injuries and Illnesses in the U.S. by Industry. Washington, D.C.

BLS (U. S. Department of Labor, Bureau of Labor Statistics). 1992. Occupational Injury and Ilnesses in the United States by Industry, 1991. Bulletin 2424.

BLS (U. S. Department of Labor, Bureau of Labor Statistics). 1993. 1992 Census of Fatal Occupational Injuries.

CFR (Code of Federal Regulations). Title 29, Chapter 1910.120, Hazardous Waste Operations and Emergency Response.

CFR (Code of Federal Regulations). Title 10, Chapter 835, Occupational Radiation Protection, the Final Rule. Federal Register 58: 65458-65512. December 14, 1993.

CFR (Code of Federal Regulations). Title 29, Part 126, Safety and Health Regulations for Construction, Subpart D, Occupational Health and Environmental Controls, Subsection 1926.65, Hazardous Waste Operations and Emergency Response. CFR rev. as of July, 1994.

CFR (Code of Federal Regulations). Title 40, Chapter 191. Environmental Radiation Protection Standards for Management and Disposal of Spent Nuclear Fuel, High-Level, and Transuranic Wastes.

DOE (U. S. Department of Energy). Radiation Protection for Occupational Workers. Order 5480.11.

DOE (U.S. Department of Energy). 1989. General Design Criteria. Order 6430.1A. April 1989.

DOE (U. S. Department of Energy). 1991b. Environmental Restoration and Waste Management Five-Year Plan 1993-1997. FYP DOE/S-0089P. 
DOE (U. S. Department of Energy). 1991a. Guidelines for the Selection of Chemical Protective Clothing. Performance, Availability, and Source of Chemical Protective Clothing. DE-02357T, UCRL-ID109106. Office of Environment, Safety, and Health.

DOE (U.S. Department of Energy). 1992. Occupational Injury and Property Damage Summary. JanuaryDecember 1991. Office of the Deputy Assistant Secretary for Safety and Quality Assurance.

EG\&G (EG\&G Idaho, Inc.). 1993a. Facsimile tramsmission from B. Millet, EG\&G Management Information System, to P.A. Scofield, Martin Marietta Energy Systems. January 6, 1993.

EG\&G (EG\&G Idaho, Inc.). 1993b. Facsimile transmission from B. Millet, EG\&G Management Information System, to P.A. Scofield, Martin Marietta Energy Systems. January 8, 1993.

Ellis, F.P. 1972. "Mortality from Heat Stress Aggravated Illness in the United States." Environ. Rsch. 5:1-58.

EPA (U.S. Environmental Protection Agency). 1985d. Dust Control at Hazardous Waste Sites. EPA 540/2-85/003.

EPA (U.S. Environmental Protection Agency). 1985c. Evaluation of Air Emissions from Hazardous Waste Treatment, Storage, and Disposal Facilities. EPA/600/2-85/057.

EPA (U. S. Environmental Protection Agency). 1985b. Rapid Assessment of Exposure to Particulate Emissions from Particulate Emissions from Surface Contaminated Sites. EPA/600/8-85/002. Office of Health and Environmental Assessment. February 1985.

EPA (U.S. Environmental Protection Agency). 1985d. Field Standard Operating Procedures for Establishing Work Zones, Federal Standard Operating Procedures, No. 6. OSWER Directive 9285.2-04. Office of Emergency and Remedial Response.

EPA (U.S. Environmental Protection Agency). 1987b. Low-Level Radioactive Wastes Model Documentation. PATHRAE-EPA Methodology and User's Manual. EPA/520/1-87-028. December 1987. 
EPA (U.S. Environmental Protection Agency). 1987a. User's Guide for PAL 2.0, A Gaussian Plume Algorithm for Point, Area, and Line Sources. EPA-600/8-87/009. Atmospheric Research and Exposure Assessment Laboratory. March 1987.

EPA (U.S. Environmental Protection Agency). 1988e. Availability of the Integrated Risk Information System (IRIS). Federal Register 53: 20162. June 2, 1988.

EPA (U.S. Environmental Protection Agency). 1988b. Guidance on Remedial Actions for Contaminated Groundwater at Superfund Sites. EPA/540/G-1-88/003.

EPA (Environmental Protection Agency). 1988e. Limiting Values of Radionuclide Intake and Air Concentrations and Dose Conversion Factors for Inhalation, Submersion and Ingestion. EPA-520/1-88020. Office of Radiation Programs. September 1988.

EPA (U.S. Environmental Protection Agency). 1988c. Protocols for Generating Unit-Specific Emission Estimates for Equipment Leaks of VOC and VHAP. EPA 450/3-88-010. Office of Air Quality Planning and Standards.

EPA (U.S. Environmental Protection Agency). 1988a. Superfund Exposure Assessment Manual. EPA/540/1-88/001. OSWER Directive 9285.5-1. Office of Remedial Response. Washington, D.C.

EPA (U. S. Environmental Protection Agency). 1988d. A Workbook of Screening Techniques for Assessing Impacts of Toxic Air Pollutants. EPA-450/4-88-009. Office of Air Quality Planning and Standards. Research Triangle Park. September 1988.

EPA (U.S. Environmental Protection Agency). 1989c. Air/Superfund National Technical Guidance Study Series, Volume III: Estimation of Air Emissions from Cleanup Activities at Superfund Sites. EPA 450/189-003. Office of Air Quality Planning and Standards. Research Triangle Park, NC.

EPA (U.S. Environmental Protection Agency). 1989b. Exposure Assessment Methods Handbook. EPA/600/--. Exposure Assessment Group, Office of Health and Environmental Assessment. 
EPA (U.S. Environmental Protection Agency). 1989a. Risk Assessment Guidance for Superfund (Vol. I) Human Health Evaluation Manual (Part A), Interim Final. EPA/540/1-89/002. Office of Emergency and Remedial Response. Washington, D.C.

EPA (U.S. Environmental Protection Agency). 1989d. Site Program Demonstration Test: In situ Stabilization, Solidification, and Vacuum Extraction. EPA/540/5-89/003A, 004A, 005A.

EPA (U.S. Environmental Protection Agency). 1990. User's Guide to Tscreen, a Model for Screening Toxic Air Pollutant Concentrations. EPA-450/4-90-013. Office of Air Quality Planning and Standards, Office of Air and Radiation. December 1990.

EPA (U.S. Environmental Protection Agency). 1991a. Air/Superfund National Technical Guidance Study Series Emission Factors for Superfund Remediation Technologies. EPA 450/1-91-001.

EPA (U. S. Environmental Protection Agency). 1991d. Compilation of Air Pollution Emission Factors, Vol. 1 and Supplements A, B, C, D, September 1985-1991. Research Triangle Park, NC.

EPA (U.S. Environmental Protection Agency). 1991b. Guide for Conducting Treatability Studies: Soil Washing. EPA/540/2-91/020A.

EPA (U.S. Environmental Protection Agency). 1991c. Risk Assessment Guidance for Superfund: Volume 1: Human Health Evaluation Manual (Part B, Development of Risk-Based Preliminary Remediation Goals). EPA 9285.7-01B. Office of Emergency and Remedial Response.

EPA (U.S. Environmental Protection Agency). 1992a. Air/Superfund National Technical Guidance Study Series: Screening Procedures for Estimating the Air Impacts of Incineration at Superfund Sites. EPA450/1-92-003. Office of Air Quality Planning and Standards. Research Triangle Park, NC.

EPA (U.S. Environmental Protection Agency). 1992b. HEAST (Health Effects Assessment Summary Tables). OHEA ECAO-CIN-821. Office of Emergency and Remedial Response. Environmental Criteria Assessment Office. Cincinnati, $\mathrm{OH}$. 
EPA (U.S. Environmental Protection Agency). 1992c. Methods for Estimating Diffuse or Fugitive Air Emissions of Radionuclides at DOE Facilities. Draft Report. Prepared for the U. S. Environmental Protection Agency. Office of Radiation Programs. October 1992.

Favata, E.A., G. Buckley, M. Gochfeld. 1990. "Heat Stress in Hazardous Waste Workers: Evaluation and Prevention." Occupational Medicine: State of the Art Reviews, 5:1, 79-91, January-March 1990.

Grove Engineering. 1992. MicroShield Version 4, MicroShield User's Manual. Rockville, Maryland.

Hanna, S.A., Briggs, G.A., Hosker, Jr. R.P. 1982. Handbook on Atmospheric Diffusion. DOE/TIC11223. Atmospheric Turbulence and Diffusion Laboratory, National Oceanic and Atmospheric Administration. U.S. DOE Technical Information Center.

Hanson, W.C. 1980. Transuranic Elements in the Environment. U.S. Department of Energy, Office of Health.

Hardy, R. 1993. Facsimile transmission from R. Hardy, MK Environmental Services Division, Boise Idaho to P. Scofield, Martin Marietta Energy Systems. February 18, 1993.

ICRP (International Commission on Radiological Protection). 1977. Recommendations of the International Commission on Radiological Protection. ICRP Pub. 26. Pergamon Press. New York.

ICRP (International Commission on Radiological Protection). 1987. Recommendations of the International Commission on Radiological Protection Vol. 17(2/3). ICRP Pub. 51. Pergamon Press. New York.

ICRP (International Commission on Radiological Protection). 1990. Recommendations of the International Commission on Radiological Protection. ICRP Pub. 60. Pergamon Press. New York.

INEL (Idaho National Engineering Laboratory). 1994. INEL Spent Nuclear Fuel and ER and WM Environmental Impact Statement. Draft. June 1994.

IT (IT Environmental Programs, Inc.). 1991. Chemical Engineering Branch Manual for the Preparation of Engineering Assessments. PN 3786-64. Prepared for the EPA, Office of Toxic Substances. 
Jayjock, M.A. 1988. "Assessment of Inhalation Exposure Potential from Vapors in the Workplace." $A m$. Ind. Hyg. Assoc. J. 49(8): 380-385.

Keith L.H., 1992. "Is Your Method of Selecting CPC Based on Reliable or Liable Data?," Occupational Health and Safety. August, 1992, 35-48

LANL (Los Alamos National Laboratory). 1986. A Guide to Radiological Accident Considerations for Siting and Design of DOE Nonreactor Nuclear Facilities. LA-10294-MS.

MMES (Martin Marietta Energy Systems). 1992. Hazard Screening Application Guide, Safety Analysis Report Update Program. ES/CSET-2/R1. June 1992.

NCRP (National Council on Radiation Protection and Measurements). 1989. Control of Radon in Houses. NCRP Report No. 103. Bethesda, Maryland.

NIOSH (U.S. Department of Health and Human Services, National Institute for Occupational Safety and Health). 1985. NIOSH/OSHA/USCG/EPA Occupational Safety and Health Guidance Manual for Hazardous Waste Site Activities. U.S. Department of Health and Human Services, Public Health Service, Centers for Disease Control, and NIOSH.

NIOSH (U.S. Department of Health and Human Services, National Institute for Occupational Safety and Health). 1986. Criteria for a Recommended Standard. Occupational Exposure to Hot Environments, Revised Criteria 1986. U.S. Department of Health and Human Services.

NIOSH (U.S. Department of Health and Human Services, National Institute for Occupational Safety and Health). 1990. NIOSH Pocket Guide to Chemical Hazards. U.S. Department of Health and Human Services. Cincinnati, $\mathrm{OH}$.

NIOSH (U.S. Department of Health and Human Services, National Institute for Occupational Safety and Health). 1992. Letter from K.W. Hanley, NIOSH, to P.A. Scofield, MMES, November 10, 1992.

NRC (U. S. Nuclear Regulatory Commission). 1977. Calculation of Annual Doses to Man from Routine Releases of Reactor Effuents for the Purpose of Evaluating Compliance with 10 CFR Part 50, Appendix I. Regulatory Guide 1.109. Washington D.C. 
NRC (U. S. Nuclear Regulatory Commission). 1987. Methods for Estimating Radioactive and Toxic Airborme Source Terms for Uranium Milling Operations. Regulatory Guide 3.59. PB87-92670-2. Office of Nuclear Regulatory Research. Washington, D.C.

NRC (U. S. Nuclear Regulatory Commission). 1988. Nuclear Fuel Cycle Facility Accident Analysis Handbook. NUREG-1320.

NRC (U.S. Nuclear Regulatory Commission). 1989. Calculation of Radon Flux Attenuation by Earthen Uranium Mill Tailings Covers. Regulatory Guide 3.64. Office of Nuclear Regulatory Research. Washington, D.C.

NSC (National Safety Council). 1991. Accident Facts, 1991 Edition. Chicago, IL.

ORNL (Oak Ridge National Laboratory). 1995a. Waste Management Programmatic Environmental Impact Statement Methodology for Estimating Human Health Risks Associated with Waste Management. ORNL-6864. Prepared by the Center for Risk Management, Oak Ridge National Laboratory, for the Department of Energy. May 1995.

ORNL (Oak Ridge National Laboratory). 1995b. Environmental Restoration Programmatic Environmental Impact Statement Methodology for Estimating Human Health Risks. ORNL-6865. Prepared by the Center for Risk Management, Oak Ridge National Laboratory, for the Department of Energy. 1995.

OSHA (U.S. Department of Labor, Occupational Safety and Health Administration). 1990. Analysis of Construction Fatalities. The OSHA Data Base 1985-1989. Office of Construction and Engineering.

PNL (Pacific Northwest Laboratory). 1992. Residual Radioactive Contamination from Decommissioning: Technical Basis for Translating Contamination Levels to Annual Total Effective Dose Equivalent. Vol. 1. NUREG/CR-5512. PNL-7994.

Roberts, D.L. 1987. "Heat Stress." Occupational Health and Safety, June 1987.

Vilenskii, D.G. 1960. Soil Science. 3rd ed. A. Birron and Z.S. Cole, translators. Published by the Israel Program for Scientific Translations for the National Science Foundation and the Department of Agriculture. 
DOE Reading Room

1301 Clay Street

Oakland, CA 94612

The State (DTSC) Library

Lincoln Plaza Building

4th and $P$ Street

Sacramento, CA 92410

Lawrence Livermore Eastgate Visitor

Center

Greenville Road

Livermore, CA 94550

Simi Valley Public Library

Tapo Canyon Road

Ventura, CA 93001

The State (DTSC) Library

State of California

P.O. Box 806

Sacramento, CA 95812-0806

Davis Public Library

14th Street

Davis, CA 95617

Berkley Public Library

Kittredge and Shattuck

Berkley, CA 94794

MINSY Public Affairs Office Code

1160-Building 47

Vallejo, CA 94592-5100

SNL/CA Public Reading Room

7011 East Avenue

Building 901

Livermore, CA

Government Reference Center

Mesa County Public Library

530 Grand Avenue

Grand Junction, CO 81501
Technical Resource Center

Grand Junction Project Office

2597 B 3/4 Road

Grand Junction, CO 815.03

Rocky Flats Environmental Technology Site

Reading Room

Front Range Community College Library

3645 West 112th Avenue

Westminster, CO 80030

U.S. EPA Region VIII

Attn: Michelle Bontrager

999 18th Street, Suite 500

Denver, CO 80202-2405

Colorado Department of Health

Attn: Dan Scheppers

4300 Cherry Creek Drive South

Denver, CO 80222-2405

Rocky Flats Citizens Advisory Board

Attn: Ken Korkia

9035 Wadsworth Parkway, Suite 2250

Westminster, CO 80021

Standley Lake Library

Attn: Kathy Hollaran

8485 Kipling Street

Arvada, CO 80005

Windsor Public Library

Attn: Mary Ellen Johnson

323 Broad Street

Windsor, CT 06095

Jacksonville Public Library

Documents Department

122 North Ocean Street

Jacksonville, FL 32202

Information Repository Center

Largo Public Library

351 East Bay Drive

Largo, FL 34640 
Martin Marietta Specialty Components

Community Relations Center

7381 114th Avenue, North, Suite 403A

Largo, FL 34643

Pinellas Park Public Library

7770 52nd Street, North

Pinellas, FL 34665

Atlanta Public Library

Government Documents Section

Attn: Gene Hughs

1 Margaret Mitchell Square

Atlanta, GA 30303

Chatham County Public Library

2002 Bull Street

Savannah, GA 31401

Reese Library

Attn: Elfriede McLean-Document Center

Augusta College

2500 Walton Way

Augusta, GA 30904-2200

Pearl Harbor Naval Base Library

Code 90L

1614 Makalapa Drive

Pearl Harbor, HI 96860-5350

Aiea Public Library

99-143 Monanalua Road

Aiea, HI 96701

Hawaii State Library

478 South King Street

Honolulu, HI 96813

Pearl City Public Library

1138 Waimano Home Road

Pearl City, HI 96782
Boise Public Library

Attn: Julie Davis

Government Documents Section

715 S. Capitol Boulevard

Boise, ID 83702

City of Burley Public Library

Attn: Mona Kenner

1300 Miller Avenue

Burley, ID 83702

Clearwater Memorial Library

Attn: Jill Lynch

402 Michigan Avenue

P.O. Box 471

Orofina, ID 83544

INEL Oversight Program Library

Department of Health \& Welfare

Attn: Nancy Quirk

1410 North Hilton, 3rd Floor

Boise, ID 83706

INEL Technical Library

1776 Science Center Drive

P.O. Box 1625

Idaho, ID 83415-2300

Idaho Falls Public Library

Attn: Ginny Atwood

457 Broadway

Idaho Falls, ID 83402

State Library

Attn: Stephanie Kirkay

325 West State Street

Boise, ID 83702

Library \& Archives State Historical Society

Attn: William E. Tydeman, Archivist

450 North Fourth Street

Boise, ID 83209 
State University Library

Documents Department

Attn: Larry Murdock

P.O. Box 8089

Pocatello, ID 83209

Pocatello Public Library

Attn: Gaila Clough

113 S. Garfield

Pocatello, ID 83204

Shoshone-Bannock Library

Attn: Ardith Peyope

Bannock \& Pima Streets

HRDC Building

Fort Hall, ID 83203

Twin Falls Public Library

Attn: Linda Parkinson

434 Second Street, East

Twin Falls, ID 83301

Consolidated Free Library

Attn: Lee Starr

Hayden Branch

8385 North Government Way

Hayden Lake, ID 83835

City of Emmett Public Library

Attn: Marsha Werle

275 South Hayes

Emmett, ID 83617

Lemont Public Library

Attn: Jackie

810 Porter Street

Lemont, II 60439

U.S. DOE Public Document Room

Document Dept., University Library

3rd Floor Center

University of Illinois at Chicago

801 S. Morgan Street

Chicago, IL 60607
Bedford Park Public Library

Attn: Head Librarian

7816 West 65th Place

Bedford Park, IL 60510

Bridgeview Public Library

Attn: Head Librarian

7840 West 79th Street

Bridgeview, IL 60455

Ames Lab

111 T.A.S.F.

Attn: Steve Karsjen

Ames, IA 50011

Ames Public Library

515 Douglas Avenue

Ames, IA 55001

Environmental Information Center 175 Freedom Boulevard

Kevil, KY 40253

Rice Public Library

8 Wentworth Avenue

Kittery, ME 03904

Red Bridge Branch

Mid-Continent Library

11140 Locust Street

Kansas City, MO 64108

Columbia Public Library

Attn: Marilyn McCleod

100 West Broadway

Columbia, MO 65203

Carson City Public Library

Attn: Wendell Huffman

900 North Roop Street

Carson City, NV 89701 
Nevada Test Site Reading Room

Coordination \& Information Center

Attn: Cinde Ashley

3084 South Highland Drive

Las Vegas, NV 89109

Nevada State Library

Attn: Patricia Deadder

Capitol Complex

Carson City, NV 89710

Portsmouth Public Library

8 Islington Street

Portsmouth, NH 03601

Maywood DOE Public Info Center 43 West Pleasant Avenue

Maywood, NJ 07607

Middlesex County Library

Plainsboro Branch

P.O. Box 278

Plainsboro, NJ 08536

National Atomic Museum

Kirkland Air Force Base

20358 Wyoming Boulevard, South

Albuquerque, NM 87116

Albuquerque Technical Vocational Institute

Main Campus Library

525 Buena Vista Drive, SE

Albuquerque, NM 87116

Museum Park Complex

15th \& Central

Suite 101

Los Alamos, NM

Longwood Public Library

800 Niddle County Road

Middle Island, NY 11953
Records Center

26 Federal Plaza

29th Floor, Room 2900

New York, NY 10278

Mastics-Moriches-Shirley

Community Library

425 William Floyd Parkway

Shirley, NY 11967

Brookhaven National Laboratory

Research Library Building 477A

Upton, NY 11973

Colonie Library

629 Albany-Shaker Road

Loudenville, NY 12211

Saratoga Springs Library

Attn: Claudia Hayes

320 Broadway

Saratoga Spring, NY 12866

Schenectady Public Library

Attn: Tim McGowan

Main Branch

99 Clinton Street

Schenectady, NY 12305-2083

Jennifer Nelson, Public Affairs

MS-Trailer A

10282 Rock Springs Road

West Valley, NY 14171

Town of Concord Library

23 North Buffalo Street

Springville, NY 14141

Buffalo \& Erie Bounty Public Library

Science \& Technology Department

Lafayette Square

Buffalo, NY 14203

EPA Records Center

290 Broadway

New York, NY 10007-1866 
Olean Public Library

Attn: Lance Chaffee

134 N. 2nd Street

Olean, NY 14760

Brunswick County Government Center

Attn: Andrea Merklinger

45 Court House Drive, N.E.

Bolivia, NC 28422

New Hanover County Public Library

Attn: Daniel Horn

201 Chestnut Street

Wilmington, NC 28401

Columbus Metropolitan Library

Main Branch

96 S. Grant Avenue

Columbus, $\mathrm{OH} 43215$

Northside Branch Library

1423 N. High Street

Columbus, $\mathrm{OH} 43215$

State Library of Ohio

Attn: Clyde Hordusky

65 S. Front Street

Columbus, $\mathrm{OH} 43215$

West Jefferson Public Library

Attn: Sharon Shrum

270 Lilly Chapel Road

West Jefferson, OH 43162

Kent State University

Ashtabula Campus Library

3431 W. 13th Street

Ashtabula, OH 44004

Public Environmental Information Center

10845 Hamilton Cleves Highway

Harrison, $\mathrm{OH} 45030$
Miamisburg Senior Adult Center

Public Reading Room

305 Central Avenue

Miamisburg, OH 45343

DOE Environmental Information Center

505 West Emmitt Avenue

Suite 3

Waverly, $\mathrm{OH} 45690$

Portland State University

Branford Price Millar Library

Attn: Michael Bowman

SW Harrison and Park

Portland, OR 97202

Carnegie Library

Attn: James Bobick

Science and Technology Department

4400 Forbes Avenue

Pittsburgh, PA 15213

Charleston County Library

Attn: Nancy Woodward

404 King Street

Charleston, SC 29403

DOE/SRS Public Reading Room

Savannah River Operations Office

Attn: Becky Craft

P.O. Box A

Aiken, SC 29802

South Carolina State Library

Attn: Mary Bostick

1500 Senate Street

Columbia, SC 29201

Gregg-Graniteville Library

University of South Carolina-Aiken

Attn: Allison Johnson

171 University Parkway

Aiken, SC 29801 
DOE Environmental Information Resource

Center (IRC)

105 Broadway

Oak Ridge, TN 37830

Clinton Public Library

Attn: Jane Giles

118 South Hicks Street

Clinton, TN 37716

DOE Public Reading Room

Oak Ridge Operations Office

Attn: Amy Rothrock, Room 112B

55 Jefferson Circle

Oak Ridge, TN 37831

Lawson McGhee Public Library

Attn: Nelda Hill

500 West Church Avenue

Knoxville, TN 37902

Oak Ridge Public Library

Civic Center

1401 Oak Ridge Turnpike

Oak Ridge, TN 37830

Memphis/Shelby County Public Library and Information Center

Attn: Government Publications Dept.

1850 Peabody Avenue

Memphis, TN 38104

Oliver Springs Public Library

Attn: Jennifer Newcome

607 Easterbrook Avenue

Oliver Springs, TN 37840

Rockwood Public Library

Attn: Margaret Marrs

117 North Front Avenue

Rockwood, TN 37854
Amarillo College Library

Attn: Karen McIntosh

Lynn Library, DOE Reading Room

2201 S. Washington

Amarillo, TX

Carson County Library

Public Reading Room

Attn: Teri Keotting

P.O. Box 339

401 Main Street

Panhandle, TX 79060

Mae S. Bruce Public Library

Attn: Rose Holloway

P.O. Box 950

13302 6th Street

Santa Fe, TX 77510

Friendswood Public Library

Attn: Mary Perroni

$416 \mathrm{~S}$. Friendswood

Friendswood, TX 77546

Helen Hall Public Library

Attn: Shelly Leader

400 West Walker

League City, TX 88537

Houston Public Library

Attn: Carol Johnson

500 McKinney

Houston, TX 77002

La Marque Public Library

Attn: Greg Burns

1011 Bayou Road

La Marque, TX 77568

Genevieve Miller Public Library

Ms. Kathleen Brooks

8005 Barry Street

Hitchcock, TX 77563 